Portland State University

PDXScholar

Spring 6-4-2015

\title{
Identity and Investment in the Community ESL Classroom
}

Jennifer Marie Sacklin

Portland State University

Follow this and additional works at: https://pdxscholar.library.pdx.edu/open_access_etds

Part of the First and Second Language Acquisition Commons Let us know how access to this document benefits you.

\section{Recommended Citation}

Sacklin, Jennifer Marie, "Identity and Investment in the Community ESL Classroom" (2015). Dissertations and Theses. Paper 2326.

https://doi.org/10.15760/etd.2323

This Thesis is brought to you for free and open access. It has been accepted for inclusion in Dissertations and Theses by an authorized administrator of PDXScholar. For more information, please contact pdxscholar@pdx.edu. 
Identity and Investment in the Community ESL Classroom

\author{
by \\ Jennifer Marie Sacklin
}

A thesis submitted in partial fulfillment of the requirements for the degree of

\author{
Master of Arts \\ in \\ Teaching English to Speakers of Other Languages
}

Thesis Committee:

Kimberley Brown, Chair

Kathryn Harris

John Hellermann

Portland State University

2015 
Abstract

After Norton Peirce's (1995, Norton, 2000) groundbreaking work in conceptualizing identity as "multiple, changing, and contradictory," many researchers have explored language learners' identities. However, few studies of identity have been conducted within the "overlooked and understudied" (MathewsAydinli, 2008) context of adult community ESL (English as a Second Language), and even fewer studies have focused on LESLLA (low-educated second language and literacy acquisition) learners in mainstream community ESL programs.

This thesis, based on a case study of an adult LESLLA learner in a community ESL class, analyzes how this student's identity, the social context of her life, and the classroom space shaped her investment in participating in the ESL class.

Ethnographic interviews revealed that the participant's investment in language learning was linked to her identity in multiple and contradictory ways: while the participant eventually left the ESL program, her self-identification as 'no preparada' (uneducated) and therefore 'burra' (stupid) seemed to be a motivating challenge, not an insurmountable obstacle, and her sense of investment in language learning remained strong even though her in-class participation was limited.

The results have pedagogical as well as theoretical implications: there is clearly value in engaging learners' lives in the classroom as well as including learners' voices in research to have a clearer recognition of how learners see themselves and their "possible selves" (Dörnyei, 2009) to be able to understand the complex factors that underlie their investments in language learning. 
Dedication

This thesis is dedicated to PSU's Applied Linguistics Department. Thank you, Kim, for always encouraging me and showing me what outstanding teaching looks like; thanks, Keith, for providing exactly the right amount of support and challenge; Kathy, thank you for stoking my passion for teaching Community ESL; Janet, I loved all our discussions about diving into Critical Applied Linguistics; Nike, I always strive to emulate your dedication and organization; Steve, thanks for showing me the path of how to successfully push for policy changes in adult education; thank you, John, for guiding my first heistant steps into research; Tucker, thanks for showing me the power of using good anecdotes while teaching; Lynn, I'll never forget the "wheel of wholeness" as I strive to balance life's responsibilities; Jenny, I use what I learned in Sociolinguistics every day while teaching; and Susan, thanks for showing me how much fun exploring corpus linguistics can be! This thesis would not have been possible without all of you. 


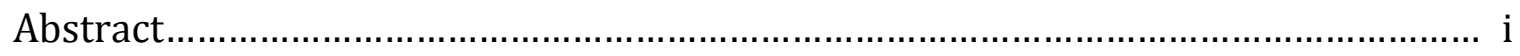

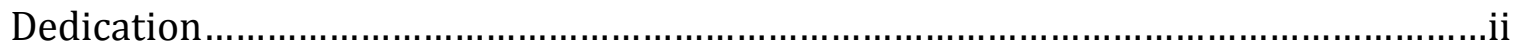

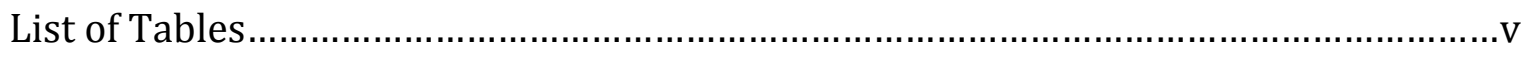

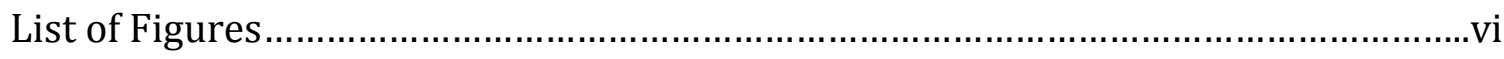

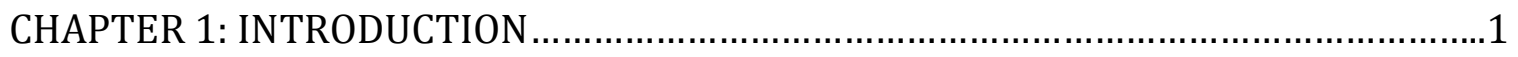

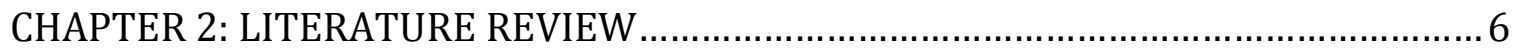

English Language Learners' Identities ................................................................. 8

Identity within the adult community ESL classroom ........................................ 9

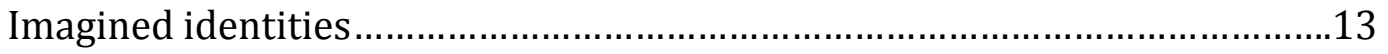

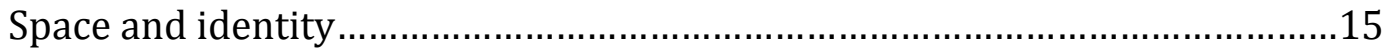

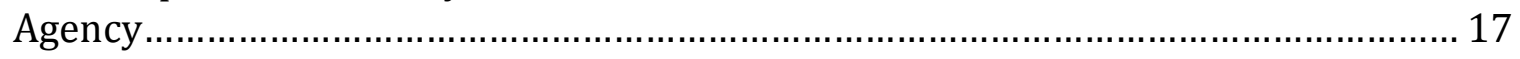

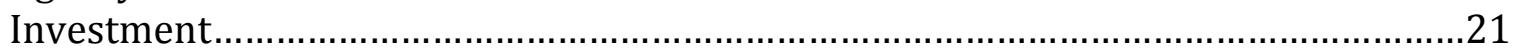

Social Context of Adult ESOL Learners' Lives in Oregon.......................................... 23

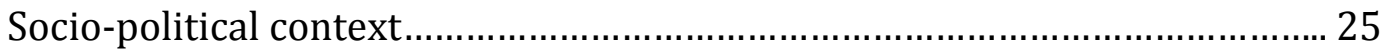

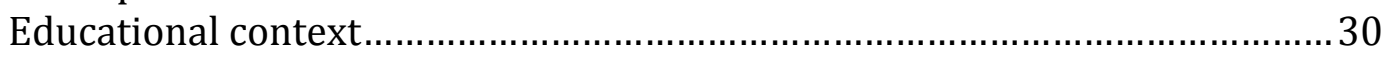

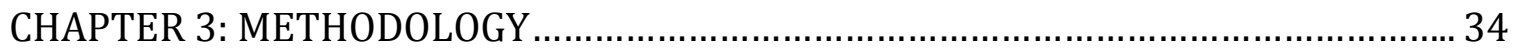

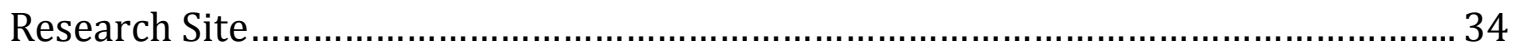

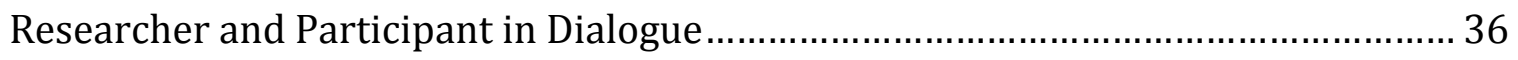

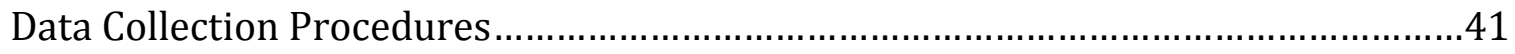

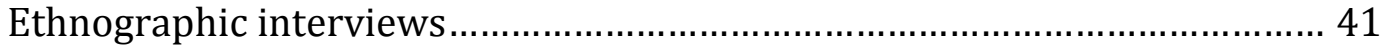

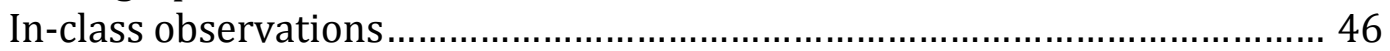

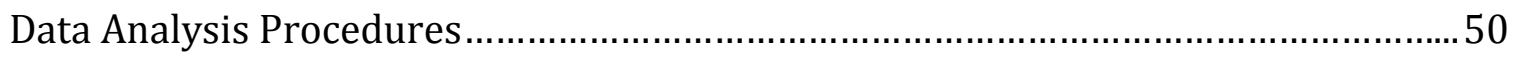

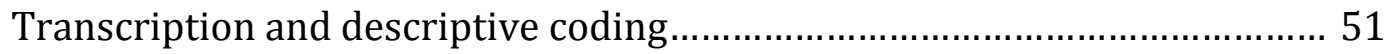

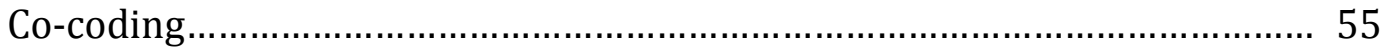

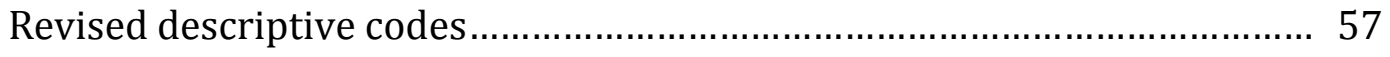

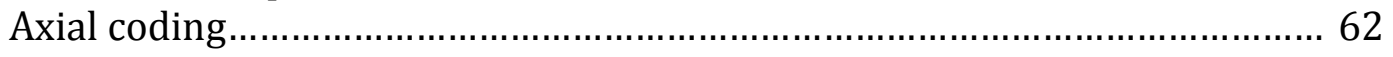

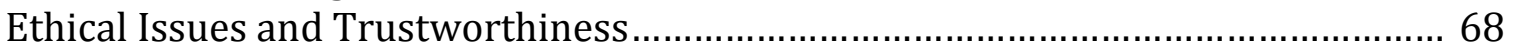

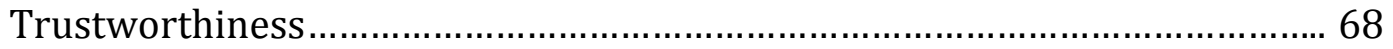

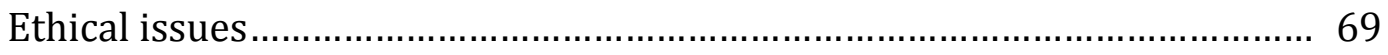

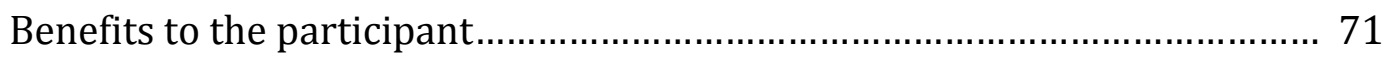

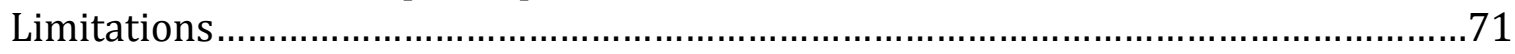

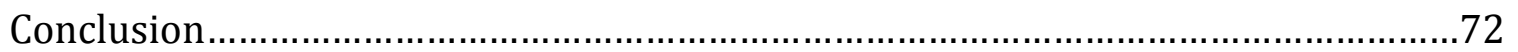


CHAPTER 4: FINDINGS AND DISCUSSION

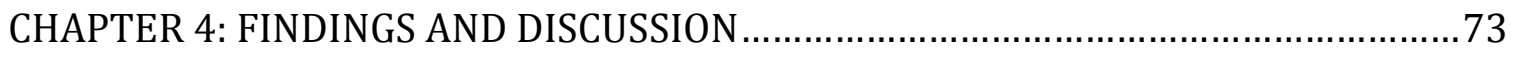

Factors Affecting Rosa's Participation in Class................................................... 76

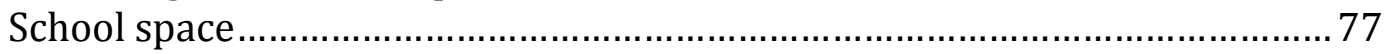

Social interactions in the class ..................................................... 77

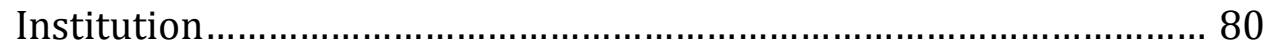

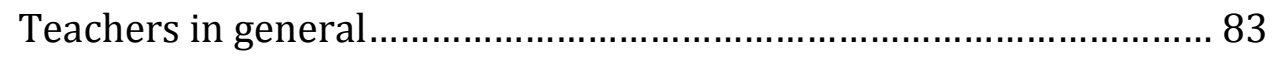

What happens in class......................................................... 87

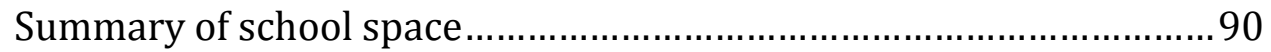

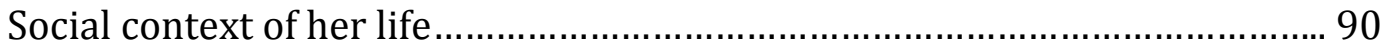

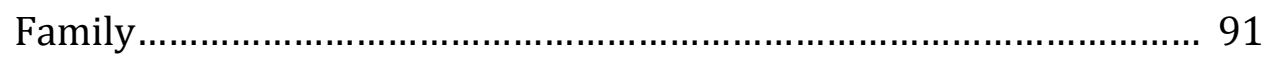

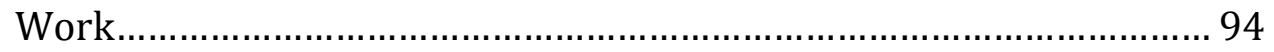

Lack of prior education ............................................................. 97

Summary of social context of her life.............................................102

Factors affecting Rosa's investment in learning English...................................... 102

Interacting with strangers in the US outside of the classroom................... 103

Legal/Police Issues.............................................................................. 109

Summary of the factors affecting Rosa's investment into learning English..115

Discussion of identity \& agency ..................................................................... 115

Agentively investing in an imagined identity ......................................... 115

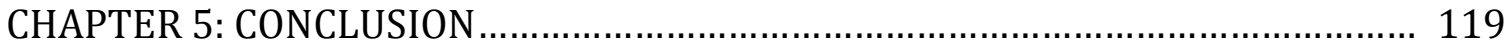

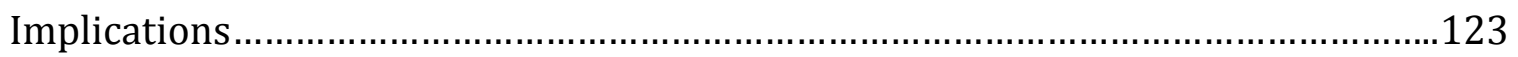

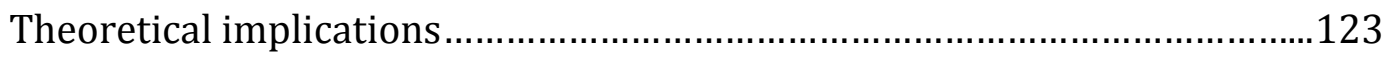

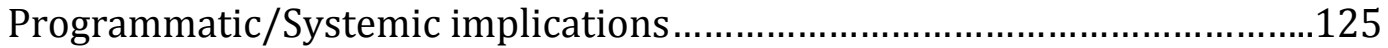

Pedagogical implications................................................................ 129

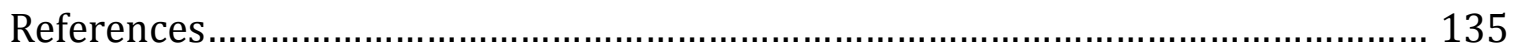

APPENDIX A: INITIAL INTERVIEW GUIDE FOR STUDENTS ............................. 148

APPENDIX B: ORAL INFORMED CONSENT SCRIPT FOR STUDENTS ......................152

APPENDIX C: INITIAL EMAIL SCRIPT FOR TEACHER ......................................154

APPENDIX D: INITIAL DESCRIPTIVE CODES AND EMERGING CATEGORIES...........155 
List of Tables

PAGE

Table 1: Final Descriptive Coding Schema ............................................................. 59 
List of Figures

PAGE

Figure 1: Excerpt of coded and annotated data sent to co-coder................................56

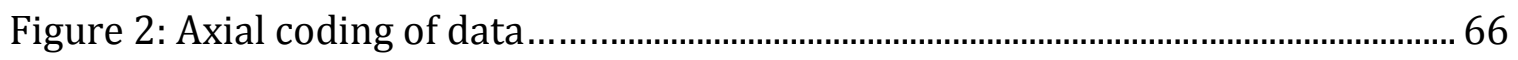




\section{Chapter 1: Introduction}

I'm sitting in Room 120 at Stumptown School, eagerly scribbling notes about the classroom, the seating arrangement, and the students' pre-class chatter, looking forward to beginning to collect data for this thesis. My participant (who chose the pseudonym of "Rosa" for this research) arrives. I smile at Rosa and she settles into a seat in the front row. From my vantage point in the back, I can see that she chats in a friendly manner with her seatmate. Some of the other students glance curiously at me as they walk in, but the teacher just introduces me as a "guest" in the classroom.

The teacher calls the students' attention to an agenda written on the board. She gives various announcements before launching into a warm-up activity: create as many words as you can using the letters that are present in the word "INTERNATIONAL." After the teacher models examples (“TEN,” “RENT”), several students start shouting out other words. The teacher encourages them to write their words down. Rosa sits still, staring at the word on the board. She turns to her neighbor and says something to him. She doesn't write anything. After two minutes, the teacher asks a few students to provide the words they wrote. She calls on Rosa, who supplies the word "LETTER." The teacher corrects her and calls on another student.

Next, the teacher asks the students go to a section in their textbooks called "The Average American." They guess what the typical American eats for breakfast, how many TVs the average American family has, and what type of house the typical American lives in. After the students guess the correct answers, the teacher draws a 
chart on the board with the various categories (e.g., "How many hamburgers do you eat every week?") and asks the students to put tally marks under each box. Rosa watches all the students go up to the board and strike their tallies representing their daily experiences. After most of the rest of the students have gone up, the teacher hands Rosa a marker and asks her to come up to the board as well. Rosa makes a few tallies before sitting down again.

The teacher reviews the sum of the class's "typical American" experiences via their tally marks. I (a pre-service teacher at this time) make a side note in my flipbook: "T has excellent time mgmt. skills. T makes excellent use of the board." Next, the teacher begins a listening exercise. Students listen to a story called "Charlie: The Average American Male" from their textbooks. They circle Charlie's marital status ("I’m not married yet") his weight ("210: I guess I could lose a little weight") and his salary (\$60,000 per year). Rosa is sitting with her head bent over her book, pencil in hand, not making a mark. I make a note in my flipbook: "R talks with neighbor. R never supplies answer during T-elicited activity. R only answers T if T calls on R. R only participates in group activities if T prompts."

I'm puzzled. I was Rosa's teacher for five months before starting this research, and Rosa was one of the most vociferous students in the class. She always assisted her neighbors, always spoke up with examples when I asked students to provide answers, and always led every activity with energy. While Rosa isn't exactly doing nothing during this class that I'm observing, she certainly seems altered. Her lack of action is as close to non-participation as I've ever seen her. What is going on? 
Even as the number of adults who are learning English as a Second Language in non-academic contexts grows, many learners stop attending community ESL programs without advancing (Mathews-Aydinli, 2008). Some learners discontinue classes due to a "disjuncture between the learner's imagined community and the teacher's curriculum goals" (Norton, 2001, p. 170), while others continue in ESL programs while simultaneously choosing to exercise non-participation in order to resist dominant narratives of being positioned into certain identity roles (Miller, 2009). Why learners choose to participate or not participate in (or drop out of) ESL classes can only be understood if we understand "learners as people" (Lantolf \& Pavlenko, 2001, p. 145) and if we approach research on English Language Learners with an "increased 'emic' sensitivity" (Firth \& Wagner, 1997, p. 285). As SkiltonSylvester (2002) contends, learners' investment in participating in community ESL programs can be best understood by examining the relationship between learners' identities, the contexts of their lives in the United States, and the social space of the classroom.

This thesis focuses on the investment of one adult learner of English. It investigates how she characterizes the connections between her identity, the social context of her life, and the classroom space. Rosa is, in many ways, extraordinary. And yet, her story is not that dissimilar from that of many other ESL students. Her story provides insight into the complex processes of investment in learning and non-participation in a classroom space, which remain topics of great concern in applied linguistics.

What if we, as researchers and teachers, could hear all of our students' 
stories? How much extraordinary insight could we gain into the complicated process of language learning if we centered learners' voices? What if we could listen to the power of a woman learning to become literate and claiming the right to speak within a system that is constantly denying her agency? Analyzing these voices enables us to understand the "deeply political nature of literacy, of poverty, and of voice" (Ramanathan, Pennycook, and Norton, 2010 p. xii), which could allow us to create liberatory models of education in which the world could be transformed (Freire, 1970).

I feel priviledged to have worked with Rosa on this thesis; I learned a great deal about the complexity of the community ESL classroom, especially from the perspective of an adult learner. Rosa's narrative has illuminated the thorny path that many learners attempt to take as their lived experiences sometimes clash with the expecations of a formal classroom environment; her story has shown me the necessity of listening to and learning from students if we are to successfully engage in transformatory learning.

This thesis is especially useful for educators and researchers who want to engage with the community ESL classroom but will also benefit teachers in all ESL contexts; Rosa's words help illuminate the variety of ways we can seek to expand opportunities for students. In the next chapter, I present a review of the literature necessary to understand Rosa's investment the community ESL classroom. Chapter 3 summarizes and explains the methodology I used to collect and analyze data as well as describes the relationship between myself (the researcher) and Rosa (the participant) as we co-constructed meaning through ethnographic interviews. In 
Chapter 4, I present the results of my analysis and discuss interpretations of the data. I end with a conclusion chapter exploring the implications this study. Throughout this thesis, I emphasize Rosa's words and Rosa's experiences. Rosa chose to conduct interviews with me in Spanish (see Chapter 3 for an explanation) and I followed her lead. I did all of the transcribing and glossing of the excerpts given within this thesis; any errors are my own. 


\section{Chapter 2: Literature Review}

In this chapter, I begin by reviewing the literature on English language learners' identities before discussing investment and agency in second language learning. I also examine the social context of learners' lives and the social space of the ESL classroom. Each of these constructs are necessary to understand because, as Skilton-Sylvester argues, in order to understand participation and investment, we need to understand "the participation of particular people within particular social and educational contexts, with particular purposes for learning as they play particular and multiple roles in their daily lives" (p. 10). We cannot understand a learner's investment in a classroom without examining how that learner characterizes his or her identity, what the learner's lived experiences both inside and outside of the language classroom are, and how that learner chooses to act in response to the societal and institutional power structures that limit participation within a classroom space.

Adult ESL learners face many obstacles (see any number of studies, including Norton Peirce, 1995; Norton, 2000, 2001; Skilton-Sylvester, 2002; see also my section below on the social context of learners' lives in Oregon), but by calling attention to learners' agency in imagining their own identities and investing in those imagined identities, researchers can ultimately illuminate the powerful ways in which learners navigate the structural barriers created in educational settings, even in nonacademic community ESL classes.

Investment, agency, and identity are overlapping and complementary 
constructs within the field of applied linguistics. Norton Peirce (1995) introduced investment as a sociological construct as an alternative to the psychological construct of motivation in arguing that learners invest in a target language with the aim of securing cultural capital (Bourdieu, 1991) while also "organizing and reorganizing a sense of who they are and how they relate to the social world" (Norton Peirce, p. 18). Agency can be seen as the "resisting power or transgressing (in)visible boundaries" (Ramanathan, Pennycook, and Norton, 2010, p. x). Lantolf and Pavlenko show how agency and investment co-occur by concluding that "[i]t is agency that...defines a myriad of paths taken by learners" (2001, p. 146).

I will follow Norton (2000) in defining identity as "...how a person understands his or her relationship to the world, how that relationship is constructed across time and space, and how the person understands possibilities for the future" (p. 5). In introducing investment to applied linguistics, Norton Peirce argued that "an investment in the target language is also an investment in a learner's own social identity, an identity which is constantly changing across time and space" (p. 18); it would therefore be impossible to study investment without considering identity. Identity and agency are inextricably linked because, as Holland, Lachicotte, Skinner, and Cain (1998) argue, we can be agents in the creation of our own identity, or we can be denied agency by being positioned by others.

Learners' investment, agency, and identities are also shaped by the social space of the classroom. In order to understand how learners conceptualize themselves within the classroom space, I will use Lefebvre's (1974/1991, as cited in Zhang, 2006) concept of lived space. Zhang describes lived space as "a space of pure 
subjectivity, of human experiences (Watkins, 2005), of people's sense-making, imagination, and feeling - that is, their local knowledge - of the organisational space as they encounter it" (p. 221). I also review literature on identity shifts within spaces in order to move closer to asking the question of how the intertwining constructs of the socially constructed classroom space, learners' identities, and the social context of learners' lives in the United States affect learners' investment in community ESL programs.

\section{English Language Learners' Identities}

Recent research has been prolific on the subject of how language learners construct their identities and how societal and classroom discourses position learners within socially determined identity roles.

Norton Peirce's (1995) work was groundbreaking in connecting SLA and language teaching with poststructuralist views of identity. Using data from diaries, questionnaires, interviews, and home visits with immigrant women in Canada outside the classroom setting, Norton Peirce concluded that it was necessary to have a "comprehensive theory of social identity" in SLA (p. 12). Such a theory would link social theory conceptions of identity as "multiple, changing, and contradictory" (p. 26) with social discourses surrounding language learners (in her case, with discourses surrounding immigrants) as well as with learners' access to social networks that are, she argued, necessary to develop communicative competence, in order to understand her participants' investment in learning English.

Using Norton Peirce's work as a foundation, many other researchers have embarked on studies of students' identity and language learning. Several studies 
have looked at identity within teaching Foreign Languages other than English (Haneda, 2005; Kinginger, 2004; Lyons, 2009), EFL (Atay and Ece, 2009; King, 2008; Murphey, Jin, and Li-Chi, 2005; Rajadurai, 2010a; Rajadurai, 2010b) and ELF contexts (English as a Lingua Franca; Baker, 2009; see House, 2003, for a conflicting view). Other studies have examined academic ESL contexts with children (Rymes and Pash, 2001; Willett, 1995), adolescents (Ibrahim, 1999; McKay and Wong, 1996) and adult learners (Lee, 2008; Marshall, 2010). However, fewer studies have looked at adult language learners in ESL contexts outside the academic sphere.

Following Norton Peirce, a handful of researchers have looked at learners' identity formations outside of classroom-based formal learning spaces. Conducting ethnographic research over a period of three years in the Lao-American community and in Laos, Gordon (2004) analyzed shifts in gender identities that occurred in both Lao men and women as they came to the US and became members of Englishspeaking communities. The results of that research led Gordon to argue that second language acquisition research should "examine language acquisition as a social phenomenon influenced by men's and women's different positions vis-à-vis social, economic, and political changes" (p. 452).

It is precisely this connection between individual identities, social positioning, and language learning that Norton Peirce (1995; Norton, 2000) called the discipline's attention to and that other researchers have extended to analyzing within the context of the adult ESL classroom.

Identity within the adult community ESL classroom. Only a select handful of studies have focused on the identities of students who are taking adult 
community (nonacademic) ESL classes. In some studies, the classroom is on the periphery of the research interest: Menard-Warwick (2004) and Skilton-Sylvester (2002) focused primarily on how learners' identities affect their willingness and ability to attend ESL classes. Using narratives based on life history interviews, Menard-Warwick drew connections between learners' gender identities and their language acquisition. Menard-Warwick concluded that one participant saw ESL classes as an empowering way to resist "gendered expectations" (p. 304), while another participant saw the classes as burdensome; the latter participant attended classes only after her husband had concluded that it was her familial duty to learn English. Skilton-Sylvester (2002) offered ethnographic data to show how participants' cultural identities as Cambodian women and social identities as spouses, mothers, daughters/sisters, and workers sometimes eclipsed their desire or their ability to attend ESL classes.

Skilton-Silvester also included data from interviews with teachers that revealed that the ESL program created identities for learners that affected their learning within the classroom. To illustrate, one teacher mentioned that he had been told that students were not interested in working, so he did not consider bringing materials related to employment to the class. However, students later articulated that they were indeed interested in getting jobs, and this teacher realized he had been "censoring" the information he brought into the class (p. 21). SkiltonSilvester argued that the director of the refugee center that held the ESL class had positioned the learners into identities of "welfare recipients" who would therefore not need or want to find work (p. 21; see Tollefson, 1989, for a similar discussion of 
positioning in ESL classes in pre-settlement refugee communities).

Baynham and Simpson (2010) and Miller (2009) drew on positioning theory to directly address how teachers within adult ESL classrooms positioned learners into limited identities. Baynham and Simpson evaluated how the wider policies in Britain regarding ESOL instruction and the structure of the ESOL classes offered in the program limited learners' identity options. Teachers within the ESOL program contributed to the narrowing of learners' identities by referring to learners by their language level, calling students "entry 2s, entry 3s, level 1s" (p. 430).

Miller analyzed how English-dominant norms regarding language identities can be re-created in "ordinary" interactions within ESL classrooms. As an instructor and a researcher in an adult community ESL setting in the Midwestern US, Miller recorded classroom interactions and outside interviews with participants. She analyzed how both she and her students positioned the students as immigrants and language learners and how they (unconsciously) perpetuated the hegemonic "normality" of English as the dominant language. In an interesting intellectual argument, Miller acknowledged the dynamism and context-dependency of identity, but she chose to analyze the "relatively static identity categories such as 'ESL student,' 'adult immigrant,' 'researcher,' or 'interviewer' achieved as moments of temporary stability in the ongoing positioning work among the participants in the study" (p. 322) in order to see how the positioning of learners into certain language identities perpetuated "hegemonic language ideologies" within the classroom (p. 323).

In a similar vein, Morgan (1997) cautioned against teachers positioning 
learners within the classroom; teachers' "conceptual predispositions" regarding theories and methods in TESOL can "define and constrain the emancipatory potential of identity work in ESL" (p. 447). Although Morgan (1997) did not directly focus on students' identity transformation within the classroom, he shows how learners' social identities were in transition outside the classroom and how a lesson on intonation created a safe space for students to evaluate and compare shifts in their identities with each other.

Of all of the above studies that focused on adult language learners' identities within the classroom, only Morgan (1997) mentioned how being in the classroom could potentially cause identity shifts, and not simply identity narrowing (see also Morgan, 2004). It is essential to not lose sight of the liberatory potential of education in helping students come closer to their imagined identities (see discussion in imagined identities below); all too often, research discusses marginalized learners with a "deficit" perspective, viewing them almost as victims of a vicious system (see discussion on agency below). To illustrate, Morgan (1997) described how a lesson on intonation that he taught at a community center in Toronto, Canada brought his learners' social identities to the fore. For the lesson, Morgan selected a text featuring a wife whose husband would not let her attend English classes-a topic that had emerged during informal conversations with his students, all but two of whom were adult immigrants from Hong Kong. He asked his students to evaluate a series of options available to the wife in the text, which then allowed learners the space to foreground their out-of-class identity during their inclass participation. In other words, the activity allowed students to "compare and 
reassess private experiences" (p. 441) and give heartfelt advice to an imaginary woman without having to "reveal the family dirty laundry in public" (B. Morgan, personal communication, February 22, 2012). Morgan argued that his classroom was a space for potential shifts in identity: "[The] ESL classroom provided students with an opportunity to share their personal difficulties, evaluate them against the experiences of others, and begin to recognize them as socially constructed and potentially transformed through social action" (p. 447).

Imagined identities. An essential construct in this study is "imagined identities," which was introduced by Norton (2001) as an extension of Anderson's "imagined communities" (2006). In order to understand a learner's investment in English, it is crucial to understand how that learner views herself now (her current identity) and who she sees herself as becoming (her imagined identity). Investment in an imagined identity as a proficient speaker of English very clearly leads to an investment in learning English (Norton, 2000).

Anderson crucially conceptualized nation as an "imagined political community...imagined because the members of even the smallest nation will never know their fellow-members, meet them, or even hear of their communion" (p. 6) to political science, and applied linguists have responded to this post-structuralist view of community. Norton (2001) applied the idea of "imagined community" to SLA theory, arguing that "a learner's imagined community invite[s] an imagined identity, and a learner's investment in the target language must be understood within this context" (p. 166). Freire, while not discussing "imagined identity" directly, claimed that no learning was possible without "re-invention" of self: "Knowledge emerges 
only through invention and re-invention, through the restless, impatient, continuing, hopeful inquiry human beings pursue in the world, with the world, and with each other" (1970, p. 72).

Pavlenko and Norton (2007) expanded on the idea of imagined identities, citing Wenger (1998), who stated that "because learning transforms who we are and what we can do, it is an experience of identity" (p. 215). Pavlenko and Norton continued:

We argue that the notion of imagination as a way to appropriate meanings and create new identities, developed by Anderson (1991) and Wenger (1998), allows us to transcend the focus on the learners' immediate environment, as the learning of another language, perhaps more than any other educational activity, reflects the desire of learners to expand their range of identities and reach out to wider worlds. (p. 670)

While the concept of "imagined identities" has been included in research on L2 acquisition (e.g., Lyons, 2009), very little work has been done in English language learning specifically. In the EFL context, only Murphey, Jin, and Li-Chi (2005) specifically used the construct of "imagined identities." Murphey et al. analyze language learning histories written by Japanese and Taiwanese university students and suggest that the students constructed their identities through writing the narratives and through imagining themselves as part of L2 communities.

Although imagined identities is an empowering concept, one that provides insights into adult language learners' identity transformation, there has been only one article looking at learners' imagined identities with the adult community ESL 
context, and this article was less concerned with imagined identities than with the authors' reading of Foucault's (1980) "regimes of truth" (as cited in Carroll, Motha, and Price, 2008). Using two adult learners in community college ESL classes as participants, Carroll, Motha, and Price (2008) turned the "hopeful and constructive" conception of imagined communities around, arguing that although imagination is "essential to identity construction... such a focus on individual imagination, imagery, subjectivity, and agency has the potential to naively obscure the coercive and veiled role of hegemony within individual identity construction" (p. 168). Although I will take Carroll et al.'s warning into careful consideration, I agree with Kanno and Norton (2003), who took an affirmative view of "imagined identities" in their introduction to the special issue of the Journal of Language, Identity, and Education, remarking:

What is ultimately most exciting for the authors in this special issue is that the notion of imagined communities provides a theoretical framework for the exploration of creativity, hope, and desire in identity construction....[o]ur identities...must be understood not only in terms of investment in the "real" world but also in terms of our investment in possible worlds. (p. 248) Understanding one language learner's investment into her imagined identity can cast a powerful light on how she also invests in learning English within a classroom space.

Space and identity. The classroom space (or the space of the institution where classes are held) is a "figured world" (Holland et al., 1998) which is a "socially and culturally constructed realm of interpretation" (p. 52). Critical spatial theorists 
such as Lefebvre (1974/1991, as cited in Allen, 1999) and Soja (1989; 1996, as cited in Allen, 1999) have examined the notion of space, questioning how daily interactions with the products and productions of socially-constructed spaces and spatial ways of knowing act to shape our consciousness of what we are, what we call ourselves, what we call each other, and who else are we like-as well as what are our material circumstances. (Allen, 1999, p. 250) Lefebvre's notion of lived space provides a particularly useful link to investment in imagined identities and the experiences of marginalized learners in a classroom; Allen characterizes lived space as "the location where subaltern identities emerge as they are recovered through identity narratives and artistic or poetic representations that give presence and meaning to their divergent perceived and conceived spaces" (p. 260).

I would argue that not only is lived space a place for "subaltern identities" to emerge, but also can be a place that fosters or shapes the possibilities of the more expansive concept of "imagined identities," as described by Kanno and Norton (2003). Along with Pavlenko and Norton's (2007) case for the importance of imagination in language learning, Soja's (1996) assertion that lived space is "the space which the imagination...seeks to change and appropriate" (p. 69, as cited in Allen, 1999, p. 260) create room for an argument connecting the imagination required to create a space and the imagination required to create an identity.

The socially-constructed space of the classroom, which is inhabited by the teacher, the students, and the imaginary spaces indexed by the textbook (Whiteside, 2007), interact with the discourse of the institution where classes are held 
(McParland, 2014). These interactions form settings in which a learner's imaginary identity, or ideal future self (Dörnyei, 2009), might be able to come closer to becoming a reality, depending if the classroom and the institution support learners' agency in investing in such a future self. This thesis draws on Rosa's reports of how she views the classroom's lived space as well as my observations of the classroom space in order to better understand Rosa's investment in language learning.

\section{Agency}

Agency, a construct inextricably tied with identity and language learning, has been defined as "a relational and mediated capacity to act" (Miller, 2012, p. 441) or a "socioculturally mediated capacity to act" (Ahearn, 2010, p. 28) and many researchers view agency as simply what someone does, or what someone is able to do. Much research has been done that synonymizes learner agency and learners' self-regulation or learner autonomy; however, while self-regulation in learning or learner autonomy is certainly a part of agency, exercising agency is not simply making the choice to study a textbook on a particular day.

In the preface to Hernández-Zamora's book on decolonizing literacy, Ramanathan, Pennycook, and Norton argue that we must "pay heed to the notion of 'the political' and the importance of examining agency (and literacies) in terms of the historical and intellectual contexts we inherit" and they point out that agency can be seen "in terms of resisting power or transgressing (in)visible boundaries" (Ramanathan et al., 2010, p. x). In this thesis, I will follow this more political definition of agency.

Lantolf and Pavlenko (2001) contend that "human agency is about more than 
performance, or doing; it is intimately linked with significance. That is, things and events matter to people - their actions have meanings and interpretations" (p. 146). Coming from an SLA perspective, Lantolf and Pavlenko argue that in order to understand how and why people learn, language learners need to be "understood as people" (p. 145) who have complex and meaningful relationships with language and the social world around them. To a large degree, adult learners have not been profiled in such a way in the literature. That is why a case study can assist us in understanding how agency "defines a myriad of paths taken by learners" (Lantolf and Pavlenko, 2001, p. 146).

In their book Identity and Agency in Cultural Worlds, Holland, Lachicotte, Skinner, and Cain (1998) argue that identity is inextricably linked with agency; we can be agents in the creation of our own identity, or we can be denied agency by being positioned by others. The authors describe identity as being a form of social practice, and they argue that "identity in practice" includes A) how we "place ourselves in social fields, in degrees of relation to identifiable others" (p. 271), B) how we are positioned by others into occupying certain identity roles, C) how certain spaces allow for us to become "authors" of our own identities, and D) how, through our actions, or interactions with others, we can create "newly imagined communities" (p. 272) in which new identities are possible. These four observations about the nature of identity in practice provide a very useful theoretical connection between agency and identity.

The connection between investment in language learning and identities, then, is agency; how learners see themselves with relation to the world relates to their 
identities, but how learners choose to act with regards to their meaningful social worlds relates to human agency.

Cervatiuc (2009), in contrast to research focusing on marginalized learners (e.g., Norton, 2000), analyzed strategies that 20 adult immigrants to Canada who became proficient speakers of English had used to construct their identities as "good language learners" and "successful professionals" (p. 255). Cervatiuc concludes that learners who were able to adopt an identity as a successful, confident multilingual individuals and who were able to stop viewing the cultural clashes between their home countries and Canada as "disharmonius" (p. 263) ended up being quite successful in Canada. He argues that their successful integration into an imagined community of multilingual, multicultural individuals is the result of the learners' agency.

Pavlenko and Lantolf (2000) also argue that learners can act agentively to decide to not "fully attain" a target language and a new target self, and instead struggle to preserve their original identities in foreign environments and "assume an overarching identity as non-native speakers-legitimate but marginal members of a community" (p. 171).

Mercer (2011) maintains that agency is a complex, dynamic system that includes learners' beliefs about their agentive selves as well as their actual exercise of agency. Mercer points out that learners often have beliefs about what "good" language learning looks like, and though learners may feel compelled to work towards their ideal language learning behavior, they may act quite differently in the face of real-world challenges in learning. 
This struggle between what learners can and choose to do through their own agentive forces and what learners are not permitted to do because of institutional and discursive positioning is what Norton and Toohey call "the structure and agency issue" (2011, p. 427). Carter and Sealey (2000) discuss agency and structure by arguing that theoreticians need to be careful to pay attention to both forces:

Too great an emphasis on structures denies actors any power and fails to account for human beings making a difference. Too great an emphasis on agency overlooks the (we would claim) very real constraints acting on us in time and space. (p. 11)

Baynham (2006) also summarizes the "structure and agency issue," but he points out that:

As Collins writes, there are ways out of the structure/agency binary: We need to allow for dilemmas and intractable oppositions; for divided consciousness, not just dominated minds. . for creative, discursive agency in conditions pre-structured, to be sure, but also fissured in unpredictable and dynamic ways. (Collins, 1993, p.134, as cited in Baynham, 2006, p. 27) In the realm of language learning, Toohey and Norton (2003) explored the structure-agency tension by looking at how two learners successfully "exercised agency in resisting and shaping the access to learning provided by their environments" (p. 58) by successfully gaining access to social networks of English speakers in ways that were initially unexpected and unpredictable by the English speakers who allowed the learners access. Such acts of resisting and shaping access to learning is agentive; the learners' choice to actively seek out and engage with 
language learning can be characterized by their amount of investment into the process of learning.

\section{Investment}

A third construct tied closely to identity and agency is investment, which conceptualizes learners' relationship to the target language as well as understanding how individuals balance different parts of their lives (Norton Peirce, 1995). As Norton and Toohey (2011) explain, "[t]he construct of investment seeks to make a meaningful connection between a learner's desire and commitment to learn a language, and the language practices of the classroom or community" (p. 415). Learners can choose to invest in various aspects of their lives (family, work, education, etc.); their investment is representative of a desire to "acquire a wider range of symbolic and material resources, which will in turn increase the value of their cultural capital" (Norton Peirce, 1995, p. 17). In order to successfully teach, educators need to understand learners' investments in their learning as well as in aspects of their lives outside the classroom (Pittaway, 2005).

As investment was first conceptualized within the field of SLA, there have been a robust number of studies focusing on investment in learning foreign languages (Haneda, 2005; Kinginger, 2004) and in learning English as a Second Language (McKay \& Wong, 1996). Many researchers have examined how learners' investments in various parts of their lives affect their ability to invest in language learning, connecting investment in a second-language-speaking-self with participation in language-learning endeavors (Pavlenko \& Lantolf, 2000). In studying nonacademic adult ESL in particular, Skilton-Sylvester (2002) 
and Menard-Warwick (2004) studied how investment and identity interplay in students' language-learning trajectories. Skilton-Silvester examined how certain identity roles took precedence over language learning in her participants' lives; their investments in language learning and their ability to attend or participate in the language learning class were determined by their roles outside of class. Menard-Warwick studied how her participants' investments in their identities shaped their language-learning decisions, finding that her participants only invested in language learning "when it was congruent with the other investments they had made" (p. 307) in their families and work.

Norton and Toohey (2011) pick up the thread of non-participation in the language classroom, arguing that a language learner might ...have little investment in the language practices of a given classroom or community, which may, for example, be racist, sexist, elitist, anti-immigrant, or homophobic. Alternatively, the language learner's conception of good language teaching may not be consistent with that of the teacher, compromising the learner's investment in the language practices of the classroom. Thus, the language learner, despite being highly motivated, may not be invested in the language practices of a given classroom. The learner could then be excluded from those practices, or choose not to participate in classroom activities. In time, the learner could be positioned as a 'poor' or unmotivated language learner by others. (p. 421)

Because learners have a great deal of investment in many parts of their lives, including language learning, Pittaway (2005) argues in a position paper that it is 
paramount that educators engage learners' complex histories, current investments, and desires for the future in order to successfully teach. Pittaway further contends that acknowledging learners' various investments has a liberatory potential:

In attempting to capture the reality of learners' lives, investment attempts to acknowledge the social obstacles surrounding legitimacy and the right to speak. Engaging investment is a means of helping learners appropriate a range of symbolic, cultural, and linguistic capital that can be redeemed for legitimate access into a desired community of practice. As previously discussed, this process, or struggle, rather, begins with the interaction between an instructor and a student. This is not to say that engaging investment will erase racism or prejudice, but that instructors who actively seek to engage investment can prepare their learners to handle these issues constructively. This engagement is principled on interaction within the classroom, which can then lead to empowered interaction outside the classroom. (p. 212)

In pointing out the "social obstacles surrounding legitimacy and the right to speak" (p. 212), Pittaway drives at a principal idea in all of the research cited above on investment, agency, and identity: that of the centrality of understanding the social context of learners' lives in relation to their language-learning experiences.

\section{Social Context of Adult ESOL Learners' Lives in Oregon}

A central tenet of most research on learner identity and investment is that we must attend to the context surrounding language learning as well as the text that is produced in a language-learning environment: learners' lives outside the 
classroom greatly affect their investment in language learning and their participation in the classroom space (Norton, 2000; Pavlenko \& Blackledge, 2004). Cooke (2006) summarizes relevant research in post-structuralist approaches to studying the identities of ESOL learners, arguing that "knowing more about learners and their 'various worlds and experiences' enhances our understanding of which factors influence their English language learning" (pp. 56-57). Skilton-Sylvester (2002) maintains that it is necessary to examine learners' lives in great complexity in order to investigate participation in language learning, which "requires...paying attention to the ways that those identities are gendered and connected to their lives as members of a particular cultural and ethnic group (DiLeonardo, 1984; SkiltonSylvester, 1997)" (p. 13).

A classic model in understanding how various parts of students' lives interact is Bronfenbrenner's (2005) ecological systems theory, which examines the "nested ecosystems" of students' lives: the microsystem of the ESL classroom is greatly affected by the mesosystem of students' work and home lives and the exosystem of the professional training practices of ESL teachers; these systems are controlled by the macrosystem of "belief systems, resources, hazards, opportunity structures, life course options, and patterns of social interchange that are embedded in each of these systems" (p. 101). It is outside the scope of this thesis to examine how each of the four levels of systems interact and affect Rosa's learning, but it is important to address key facets of the social context of Rosa's life.

Therefore, I will examine both the socio-political context surrounding this study and the relevant research surrounding the educational background of adults 
who are learning a second language while learning to become literate for the first time, considering that the educational attainment of the participant in this study is a crucial connection between the social context of her life and her investment in learning English.

Socio-political context. This study took place in a city (Portland, Oregon) that tends to pride itself on being an "ecotopia" (Stroud, 1999) and in having residents "who are 'creative,' 'bohemian,' and attracted to 'diversity"' (Sullivan \& Shaw, 2011, p. 415). However, Portland, a city that can be characterized as having "racism without racists" (Bonilla-Silva, 2003), has a long history of racial divides that is necessary to address in prefacing a study on identity and English language learning. As Kubota (2002) points out,

Discussing racism is often uncomfortable, particularly in TESOL and applied linguistics. The field of L2 education by nature attracts professionals who are willing to work with people across racial boundaries, and thus it is considered a "nice" field, reflecting liberal humanism...However, this does not make the field devoid of the responsibility to examine how racism or any other injustices influence its knowledge and practice. (p. 86) In examining the racial and racialized identities of ESOL teachers, Motha (2006) asserts that "[b]ecause the spread of the English language across the globe was historically connected to the international political power of White people, English and Whiteness are thornily intertwined (Kumaravadivelu, 2003; Pennycook, 2001)" (p. 496). Motha also quotes Van Ausdale and Feagin (2002), who "contend that adults, particularly White adults, in U.S. schools are in denial about the 
seriousness of racial prejudices in the society around them" (Motha, 2006, p. 498).

Relating to identity and language learning, in their study of successful language learners in Canada, Toohey and Norton (2003) hint at the way race, manifested through physical characteristics seen as desirable to "Western eyes" gave their participants (Eva and Julie) access to social networks that otherwise would have been unattainable:

...we wonder what data we would have collected had Eva and Julie not been blonde and white-skinned, slim, able-bodied, well-dressed and attractive to Western eyes. In this regard, while her co-workers were ultimately happy to work with Eva, they remained reluctant to work with other immigrants. And in the classroom, other English language learners (notably a South Asian female student in this study) were not as successful as Julie in resisting subordination, even though they used in many cases exactly the same language to attempt this resistance. (p. 70)

As will be shown in Chapter 4, the primary driving force behind Rosa's investment in learning English was her desire to stand up for herself as a Latina woman living in the United States. Consequently, I believe it is important to understand the context surrounding Latinos' lives in the US, specifically in Oregon. While other social factors such as her gender, class, and ability certainly came into play in Rosa's learning experiences, race was an incredibly salient feature in the data (see Chapter 4), and therefore I will focus primarily on research on race in Oregon and in ESOL classrooms.

According to the 2013 American Community Survey, there are an estimated 
11.5 million Mexicans living in the United States (US Census Bureau, 2013). Rosa is, of course, an individual with her own story, but many elements of her life mirror the stories of other Mexican-born adults living in the United States. In Multnomah County, Oregon, where this research was conducted, $64 \%$ of Mexican-born adults do not have a high school diploma or equivalency; $46 \%$ are responsible for their grandchildren; and 73\% report speaking English less than "very well” (US Census Bureau, 2013). Rosa fits into each of these demographic boxes, and her ability to access education, or take advantage of the opportunities that education offers, has been affected by each of them.

As a woman with dark skin and a markedly non-White-Oregonian accent while speaking in English, Rosa has experienced racism in many forms while living in Oregon (see Chapter 4 for an analysis of these data). Oregon has a long, varied, and violent history of oppressing people of color (see Smallbone, 2006 for a discussion of the devastating effects of the Oregon Trail on Native tribes; Imarisha, 2013 for a summary of the exclusionary language in the 1857 State Constitution; Brooks, 2004 for an analysis of racist laws enacted in Oregon; Nokes, 2009 for a history of violence against Chinese immigrants; Langer, 2004 for the murderous legacy of the Ku Klux Klan, including the 1988 murder of an Ethiopian man by the Portland group East Side White Pride; Gibson, 2007 for an account of the Vanport Flood and the systemic destruction of Black neighborhoods in Portland due to urban renewal and freeway construction projects; Serbulo \& Gibson, 2013, for an examination of the colonial model of policing by Portland's primarily-White law enforcement in neighborhoods with large of-color populations; and Stroud, 1999, 
for charges of environmental racism against the City of Portland regarding policies surrounding the Columbia River Slough, a toxic and polluted waterway bordered primarily by neighborhoods where the majority of the people of color in Portland reside).

Focusing on the experience of Mexican-born adults living in Oregon, Stephen (2007) presents a compelling history. Up until the 1930s, Mexican immigration into Oregon had been increasing steadily, but a federal crackdown on immigration law created the Immigration Service, which deported about $20 \%$ of the Mexican immigrants in Oregon during the 1930s (p. 80). From 1942-1947, the bracero program brought thousands of Mexican workers into Oregon to do manual labor, primarily in agriculture. The braceros worked under incredibly harsh conditions, including "being forced to stay in fields despite freezing temperatures, lack of health care, lead poisoning from orchard work, job related injuries, transportation accidents, substandard housing and food, and more" (Gamboa, 1990, pp. 65-73, as cited in Stephen, 2007, p. 83). In 1946, White Oregonians returning from World War II began massive protests against Mexican workers and the bracero program, which helped lead to the program's end in Oregon in 1947. With the end of the program, thousands of Mexicans living in the state automatically became illegal residents (p. 83). In describing the racial history of the West, Stephen shows that throughout the $20^{\text {th }}$ century, "people of Mexican descent [were continually defined] as racially inferior, biologically suited for agricultural labor, culturally traditional and backward, and in need of supervision and programs of assimilation in order to fit with American society" (p. 150). 
Other scholars have analyzed the effects of recent anti-immigrant forces on Latinos in Oregon: Padín (2005) shows that current news coverage in the Oregonian (the most widely-circulated newspaper in the state) portrays Latinos as both an asset to society as long as they exhibit behaviors akin to Whiteness, such as autonomy and self-reliance, but they are seen as a societal deficit with cultural and behavioral deviance. Burghart (2014) examines the failure of Oregonians to pass Measure 88, a 2014 ballot measure to allow the Oregon Department of Motor Vehicles to issue driver cards to those without proof of legal presence in the United States; Burghart argues that this rejection was primarily due to nativist and White nationalist concerns and was a sign of Oregon's latent racism against Latinos (see HoSang, 2010, for a general discussion of race-based ballot initiatives).

Another facet of racism against Latinos in the US can be seen in the national English-only movement. Barker \& Giles (2002) convincingly argue that the rise of the English-only movement can be attributed to Whites' fears of the decreasing vitality of Anglo-American communities coupled with their perception of the increasing vitality of Latino vitality in the United States. Hartman (2003) quotes Ron Unz, the leader of English for the Children (a group whose financial backing helped pass English-only laws in California, Arizona, and Massachusetts; Pac, 2012), who equated bilingual educators with the perpetrators of the 9/11 terror attacks (p. 193). Pac (2012) traced the history of the English-only movement to the policy of White slave-owners separating African slaves from others who spoke their native language and to the creation of schools in the 1860s for Native American children in which "their barbarous dialects should be blotted out and the English language 
substituted" (1868 Indian Peace Commission, p. 87, as cited by Pac, 2012, p. 194). Kumaravadivelu (2008) illustrates how the growth of adult ESL education in the US was tied to goals of assimilating immigrants into mainstream (White) culture, symbolized by immigrants graduating from English classes by shedding their "ethnic identities" and becoming patriotic Americans in the "Ford English School Melting Pot" (pp. 65-66).

Understanding the history of racism in Oregon and the particular marginalization of Latinos is necessary for comprehending the socio-political context in which this study took place. Toohey and Norton (2003) call for further research in applied linguistics to develop insights into "issues of race, the body, and language learning" (p. 71), and this study provides another story of barriers that a Latina woman in the United States faces particularly within the context of adult education.

Educational context. Rosa's self-described identity position of being "burra / stupid" and "no preparada / uneducated" is a sign of her internalization of many of the reified social pressures placed on immigrants to learn English and to be literate. Rosa is a LESLLA learner (Low Education Second Language and Literacy Acquisition): she had zero years of formal education before starting at Stumptown, and she had a minimal level of self-taught literacy in Spanish. At the time of this study, Rosa had been studying at Stumptown for two to three years (she had taken intermittent terms off in order to work, so the number of months she actually attended classes at the institution was unclear) and her literacy level in English hovered near the Novice-High level on the ACTFL scale. 
In Oregon, the number of LESLLA learners enrolled in adult ESL classrooms can be difficult to ascertain. Programs that receive federal funding reported in the 2013-2014 academic year that 7.4\% (488 out of 6,560) of ESL learners in the state had no print literacy in any language. Of those students, 211 (43\%) dropped out of their adult ESL programs without completing a level (Office of Career, Technical, and Adult Education, 2014). In addition, federal funding specifically for adult ESL classes has decreased steadily since 2010 (US Department of Education, 2014). While all adult ESL learners are not necessarily LESLLA learners, their struggles to learn within a system that requires proof of continual improvement are echoed by LESLLA learners in the state who were not counted during that particular reporting year.

There is a very strong correlation between the amount of formal education a learner has gone through in his or her home country and that learner's success in learning English while in the US (Bigelow, Delmas, Hansen, \& Tarone, 2006; Condelli, Wrigley, \& Yoon, 2008; Earl-Castillo, 1990, Ramírez-Esparza et al., 2012). Spending years in formal educational settings has both benefits in the ability to complete abstract tasks (Scribner \& Cole, 1973; Sharp, Cole, \& Lave, 1979) as well as sociointeractive benefits (Ramírez-Esparza et al., 2012) in terms of being able to successfully learn in formal educational settings; in other words, the longer a person spends in school, the better that person is able to learn while being in school (DeCapua and Marshall, 2010). As Ramírez-Esparza et al. explain, "[l]iteracy and schooling are highly correlated and it has proven difficult to tease apart their independent effects (Scribner \& Cole, 1978)" (p. 544). Therefore, a person with few 
years of formal education is also likely to have low literacy skills and students who enter programs with low literacy skills often find it difficult to benefit from formal educational settings (Whiteside, 2007).

In her study of LESLLA learners enrolled in mainstream-ESL classes in California, Whiteside quoted the students' and the teacher's frustrations in the amount of learning and retention that was able to take place (the students' quotes echo Rosa's remarks very closely; see excerpts 3.a, 3.b, 3.i, 4.a, 4.d, 4.e, 4.h, 4.i, and 4.m in Chapters 3 \& 4):

All [students] but one expressed concern that they weren't learning in class: "We can't do it"; "The little I learn I forget; Listen, I'm very worried because I'm not learning" and they contrast themselves to other students who have more schooling (Ellos si aprenden- "They do understand"). The teacher expressed frustration about how the class was going: "I don't know how to teach reading at the level that they're at...feel bad for them, whenever I ask them to write in their journals it's just AGHHHH"..."The class has been such a struggle...” (p. 102)

Along with relating to struggles within a classroom setting, low literacy skills can also be a source of stigmatization in outside life. In their analysis of illiteracy in US political discourse, Clair and Sandlin (2004) point out that: "To be considered illiterate in contemporary America is not just to struggle with reading and writing it is to be deemed unworthy, unproductive, a bad parent, and deserving remarkably high levels of domestic intervention" (p.46).

This thesis contributes to our knowledge of the complexity of the 
experiences of students who are learning to become literate for the first time within the community ESL classroom. This thesis comes at a crucial time, with the great political and social pressure to achieve literacy and English language proficiency, with decreasing federal funding to support adults learning English, and with the paucity of research on the identities and investments of LESLLA learners in mainstream ESOL classes.

As far as I know, no study has examined the identities of LESLLA learners (Low Educated Second Language and Literacy Acquisition) who are taking mainstream adult ESL classes, and how their imagined identities, the lived space of the classroom, and the social context of their lives are related to their investment in learning English. The purpose of this study is to explore these connections, as guided by this question:

When describing her investment in a community ESL program, how does one adult English language learner characterize the relationship among her identity, the social context of her life, and her classroom space? 


\section{Chapter 3: Methodology}

In this chapter, I begin by describing the site and research participant as well as my background and role in the study. Next, I discuss my data collection and analysis procedures. Finally, I discuss ethical issues, benefits to the participant, and limitations to my study.

\section{Research Site}

This thesis is based on one case study of an adult student enrolled in an institution serving adults in the greater Portland area. Multnomah County (where this thesis is set) has about 750,000 residents (US Census Bureau, 2014) , at least ${ }^{1}$ $20 \%$ of whom speak a language other than English at home and 9\% of whom report speaking English less than "very well" (US Census Bureau, 2013). In the state of Oregon, there are over 6,500 adults in state-funded non-academic ESL programs (US Department of Education, 2014), and it is this population that I chose to focus my research on.

I chose to conduct my research at an institution with a systematic, quasiacademic approach to community ESL in order to avoid the uncertainty and fluctuating attendance at open-entry open-exit community classes; for the remainder of this thesis, I will use the pseudonym of "Stumptown School" for this institution. In Stumptown's ESOL program, classes at the Novice and Intermediate-

\footnotetext{
${ }^{1}$ while the Census data capture an accurate picture of many populations in the US, ethnic and racial minorities are recognized as being often undercounted in Census data (US Census Bureau, 2012) and the statistical sample of those who speak languages other than English at home may be lower than the actual population.
} 
Low levels are designed specifically for adult immigrants, refugees, permanent residents, and US citizens, and are not considered academic ESL classes. My experience volunteering and observing in Stumptown classes in Novice classes persuaded me that students at those beginning levels would likely not have the linguistic resources available to fully participate in the interviews, and students at more advanced levels are transitioning out of community ESL and into academic ESL, which is not within the scope of my study. Therefore, because the ethnographic interviews I planned to conduct were going to be linguistically demanding for participants, I decided to narrow my focus to only include participants who would be taking an Intermediate-Low class during my study.

I became involved at Stumptown during 2011 and 2012 when I volunteered in and observed various classes at the institution. In January, 2013, I joined a volunteer tutoring program that offers supplemental literacy instruction for ESOL students either through one-on-one or group tutoring at Stumptown and other learning centers throughout the greater Portland area. Through this program, I was assigned to teach a group of about 12 students at the highest-level organized literacy group available at this institution. I taught the class for five months (Winter and Spring 2013 terms). At the end of Spring term when I was no longer the students' literacy instructor, I described the study that I would be conducting starting in the Fall of 2013, and offered students the opportunity to be participants. Several students indicated an interest in the study, and when I contacted the students again at the beginning of the Fall 2013 term, only one was taking an Intermediate-Low class. This student stated that she was still interested in 
participating in my study, so on October $4^{\text {th }}, 2013$, we met again, I explained the study in depth in both Spanish and English, and I obtained informed consent from the participant, who chose the pseudonym of "Rosa."

Because Rosa is an emergent reader and has difficulty reading in English, I went through an oral consent process with her (see Appendix B). I read the informed consent script aloud to Rosa before going through each section of the informed consent script and encouraging her to ask clarification questions. I asked comprehension questions to ensure that she understood. Rosa agreed to participate in the study, and I began collecting data the following week.

\section{Researcher and Participant in Dialogue}

Before describing my data collection procedures, I wish to introduce Rosa and foreground Rosa's voice, as this thesis is entirely grounded in her reporting of her experiences. If I were introducing Rosa in my words, a typical presenting-theparticipant sentence at the beginning of a paragraph like this might include information about the participant's age and country of origin, but even those are not clear "facts." Rosa is most likely in her mid-40s and she was most likely born in Mexico.

There are several pieces of information that are true about Rosa: she first came to the United States when she was fairly young on a visit before returning to Mexico, deciding she didn't want to live there, and immigrating more or less permanently to the US. She has lived in California, Washington, and Oregon; she has had a multitude of jobs in the US: some low-wage, others not; she has had three children and has watched the children go back to Mexico; she has been married and 
separated; she has learned English "nomás así en la calle / just in the streets like that" (Interview \#1) and in formal English classes.

Rosa speaks English quickly and with (seeming) verbal confidence-set English phrases like "Oh my God” and "I don't know" roll off her tongue even when she is speaking in Spanish (e.g., during Interview \#2, she exclaimed that learning to read took up too much time, using the English "Oh my God" and the Spanglish "quitiar": "Digo, Oh my God! Hay que quitiar el trabajo, hay que no hacer nada para leer. / I say, Oh my God! You've got to quit your job, you've got to not do anything in order to read.") As her former teacher, I would assess her spoken English ability to be somewhere in the Intermediate-Mid range (along the the American Council for Teaching Foreign Languages proficiency guidelines). Her literacy level hovers around Novice-High. Rosa speaks Spanish as a first language; however, she never went to school in Mexico, which has led her to view her Spanish language skills as being deficient (she commented during our second interview that she can't speak her language perfectly), which has hindered her ability to study English:

\section{(3.a) Excerpt from Interview \#1:}

1 Y si tú no estudiastes... si, por ejemplo yo no estudié. ¡Muchas palabras yo no

2 sé qué significan en español! Ni lo sé escribir tampoco. Y digo yo, digo yo, yo

3 no puedo entender.

(3.a) GLOSSED Excerpt from Interview \#1:

1 And if you didn't go to school... if, for example I didn't go to school. I don't 2 know what a lot of words mean in Spanish! I don't know how to write them, 3 either. And I say, I say, I can't understand.

Rosa's investment in learning English is palpable. During our four interviews, she used phrases related to her desire to learn English such as "quiero 
aprenderlo / I want to learn it," "quiero estudiar / I want to study," / "tengo unas ganas de cómo hacerle / I have so much desire to learn to do it" over 25 times. At one point, she expressed her desire to learn English to be a hunger for the language: (3.b) Excerpt from Interview \#3:

1 Tengo que... como, como... como cuando uno tiene mucha hambre, quieres,

2 quieres comerte ese inglés, ipero ese inglés no se deja! [laughs] (3.b) GLOSSED Excerpt from Interview \#3:

1 I have... like, like... like when you're really hungry, you want, you want to eat 2 that English up, but that English won't let you! [laughs].

During my weekly literacy classes from January - June, 2013, Rosa attended every class except three: once because she was sick, and twice because she'd gotten into a fairly bad car accident and physically couldn't come to the class location. While her participation in my literacy class is not within the purview of this thesis, Rosa's evident desire to learn, her steady focus during class, her indomitability, and the rapport we developed during those five months allowed me to be confident that Rosa and I could successfully dialog and explore her relationship to learning English in this thesis.

While I did not conduct a narrative inquiry for the main body of the thesis, I have constructed an introduction of Rosa in the style of narrative inquiry (Murray, 2009), choosing her quotes from our interviews that represent themes that emerged during our conversations and during the data analysis process (each discrete quote rendered in $\{$ brackets\}):

(3.c) Narrative Inquiry Introduction of Rosa

1 \{Yo llegué aquí a los 18 años con mis tres hijos.\} \{Yo ya casi tengo... treinta 
años en Estados Unidos, y no sé hablar inglés, porque yo fui padre y madre para mis hijos. Yo tuve tres hijos, y yo trabajaba dos trabajos, y yo no tuve tiempo para ir a la escuela, so ahorita tengo, como dos, tres años que, que estoy tratando de aprender inglés.\} \{Yo he aprendido el inglés nomás así en la calle... Pero, ¿qué yo he ido a una escuela? No. Ni en México.\} \{De pequeña, nunca fui a la escuela....como a las ¿de cinco años? ¿cuatro años? empecé a trabajar...Trabajar en el campo, y trabajar y trabajar.\} \{Aquí...estoy yendo a la [NAME OF INSTITUTION], es todo. Y digo yo, pero si no, ya no me quieren a ir, voy a buscar otro lado. No me voy a dejar [laughs].\} \{La parte más importante de mi vida, yo creo que... sería saber inglés.\} \{Es muy difícil el inglés, pero tengo que aprenderlo porque otras personas lo saben, y yo no lo voy a saber. Aunque yo sé que yo soy la persona quizás, quizás más burra, más terca, o más [laughs] no inteligente...yo quiero aprenderlo.\} \{Yo no quiero hacer mucho, yo no más quiero saber lo que es... grammar, y la computadora, para yo desenvolverme yo sola, porque iyo ya no quiero estudiar... o una enfermera o yo voy a hacer una maestra, o hacer esto, 0 hacer el otro! No, yo no más quiero para mí misma. Defenderme yo sola.\} \{Que dice el dicho mexicano, "Un ciego no puede dirigir a otro ciego." Tiene que ver primero una, la persona para poder dirigir a otra persona. Y es lo que yo quiero. Digo, si yo no tengo nadie que me ayude acá yo tengo que buscar la manera para sobresalir yo.\}

\section{(3.c) GLOSSED Narrative Inquiry Introduction of Rosa}

\{I arrived here at 18 years old with my three children.\} \{Now, I've been in the US for almost 30 years, and I don't know how to speak English, because I was a single mother. I had three kids, I worked two jobs, and I didn't have time to go to school, so now, I've been trying to learn English for the past two or three years.\} \{I've only learned English just out on the street...But did I go to a school? No. Not even in Mexico.\} \{When I was little, I never went to school. When I was about five years old, or four years old, I began to work. To work in the fields, and work and work.\} \{Here, I'm going to Stumptown School, that's it. And I say, but if they, if they don't want me to come any more, I'm going to look someplace else. I'm not going to let them do that to me [laughs].\} \{I think the most important part of my life would be to know English.\} \{English is really difficult, but I have to learn it because other people know it, and I'm not going to know it. Even though I know that I'm perhaps, perhaps the most ignorant, most stubborn, or the most [laughs] unintelligent person, I want to learn it.\} \{I don't want to know much; I only want to know a bit about grammar, about how to use the computer, to be able to get along by myself. I don't want to study to be a nurse, or a teacher, or this, or that! No, I just want English for myself, to be able to stand up for myself. $\}$ As the Mexican saying says, "A blind man can't lead the blind;" you have to be able to see for yourself first before leading another person. And that's what I want. I mean, if I don't have anybody here who will help me, I have to look for 
22 another way to succeed for myself.

The above introduction of Rosa is crafted from my perspective of Rosataking Rosa's words out of context from various interviews and piecing them together into a coherent whole- which, while forming a useful picture of her for you (my envisioned academic audience), is also a one-sided dialogue. The text was primarily chosen by me and shaped by me; I made choices to highlight certain aspects of who Rosa presents herself as being and omitting other aspects, and this selection of "key features of Rosa" and the literary choices I made to describe my version of Rosa is already a layer of interpretation and analysis of who Rosa is (Kouritzan, 2002). Menard-Warwick asserts that:

A central assumption of my research is that narratives (and other extended texts) are co-constructed in dialogue, with the relationship between interlocutors crucial to the interpretation of the text (Vitanova, 2019, citing Bakhtin; cf Riessman, 2008). Moreover, it is important to remember that reports of research are themselves a kind of narrative (Vitanova, 2010), constructed by researchers and addressed to the expectations of an envisioned academic audience. (2014, p. 23)

Therefore, it becomes necessary to weave together Rosa's words and my interpretations of them in this research in order to form a more balanced dialogue and a more grounded narrative. I recognize that there are ongoing power dynamics that affect the positions of myself as a researcher and Rosa as a participant; part of my goal as an ethical researcher is to be cognizant of these power relationships. Throughout this thesis, I have chosen to foreground Rosa's experiences as narrated 
to me by Rosa throughout our interviews together.

\section{Data Collection Procedures}

I collected data from two sources from October, 2013 - March, 2013: four ethnographic interviews with one participant (Rosa) and observations of Rosa's actions and interactions in her Intermediate-Low class.

Ethnographic interviews. As the primary source of data, the ethnographic interviews were quite intensive, each interview lasting for 1-1.5 hours. Three interviews were conducted periodically throughout the course of the Fall 2013 term (one interview near the beginning of the term, one interview mid-way through the term, and one interview the day after the term ended), and the fourth follow-up interview was conducted 11 weeks later during March 2014 when Rosa was no longer studying English at the institution. By conducting regular interviews, I was able to establish a routine with Rosa by which she was able to discuss her experiences and beliefs in some depth. Rosa indicated her comfort level several times, saying how much she enjoyed talking with me (excerpt 3.e below), joking with me about a multitude of topics, and calling me her friend. The interviews were conducted in locations suggested by Rosa: she is one of the primary caregivers for her grandchildren, so she chose locations where her grandchildren could also play. The day of the first interview was sunny, so we met in a city park; the subsequent two interviews were held in a McDonald's PlayPlace, and the final interview was in a back corner of the eating area of the same McDonald's. Each interview was audiorecorded using a digital recorder; I asked Rosa's permission to turn on the recorder before each interview, and it stayed in the middle of the table between us for the 
duration of each interview. At one point, Rosa even pointed out how useful such an audio recorder would be for learning, because she could record her English classes and listen to them again at home.

In order to respect Rosa's ambition to learn and interact in English (as evidenced by her continued attendance in ESOL classes at this institution and her repeatedly stated desire in my literacy class to learn English), I had envisioned that the interviews could be conducted primarily in English. However, I speak Spanish sufficiently (between Advanced-High and Superior on the ACTFL scale) to be able to conduct interviews in Spanish. During my literacy class, Rosa and I had often conversed in Spanish, and when we chatted on the phone about setting up meeting times for discussing the study and for conducting the interviews, Rosa spoke with me in Spanish. At the beginning of the first interview, we had the following exchange, in which Rosa directed the switch into Spanish and I attended to her decision:

\section{(3.d) Excerpt from Interview \#1:}

1 J-So now, this is our very first interview. You get to choose a name-any

2 name. What name would you like to be known

3 R- [overlapping] Rosa

$4 \quad$ J- [overlapping] as in this research? Rosa?

5 R- Mm-hmm.

6 J- Rosa.

7 R- Rosa. [laughs]

8 J- Excellent. I like that name-Rosa. So, your other name, I will never use in 9 this research.

10 R- OK.

$11 \mathrm{~J}$ - Um, so. Rosa- for these interviews, I have some questions I want to ask you, 12 but, um, you said you had some questions for me. Y podemos hablar en 13 español si prefiere, o en inglés si prefiere. Da igual para mí. Um, so whatever 14 you're most comfortable with. So, did you want to ask me some questions 15 first? Because you had some on the phone. 
16 R- Tengo muchas preguntas como, por ejemplo, yo quiero estudiar lo que es

17 la computadora, pero no lo puedo, porque a veces necesito mucha ayuda, yo

18 entiendo. Y esa ayuda, para una maestra, yo entiendo que es muchos estudiantes para... [shrugs]. Entonces hay veces que estoy en la computadora, y la computadora me traiciona. Like, se va en otra parte, y yo estoy buscando J- ¡Ay!

R- otra parte. Quiero poner una cosa y no, no lo acepta, y agarra otra cosa. Entonces, yo quisiera ver si hay un programa

G- [overlapping] Choo-chooooo!

R- [overlapping] para que yo pueda ir.

\section{(3.d) GLOSSED Excerpt from Interview \#1:}

1 J-So now, this is our very first interview. You get to choose a name-any

2 name. What name would you like to be known

3 R- [overlapping] Rosa

4 J- [overlapping] as in this research? Rosa?

5 R- Mm-hmm.

6 J-Rosa.

7 R- Rosa. [laughs]

8 J- Excellent. I like that name-Rosa. So, your other name, I will never use in

9 this research.

10 R- OK.

11 J- Um, so. Rosa- for these interviews, I have some questions I want to ask you,

12 but, um, you said you had some questions for me. And we can speak in

13 Spanish if you prefer, or in English if you prefer. It's the same to me. Um, so

14 whatever you're most comfortable with. So, did you want to ask me some

15 questions first? Because you had some on the phone.

16 R-I have a lot of questions like, for example, I want to study the computer, 17 but I can't, because sometimes I know I need a lot of help. And that help, for

18 one teacher, I know that there are a lot of students to... [shrugs]. So there are

19 times when I'm on the computer, and the computer betrays me. Like, it goes

20 to another part, and I'm looking for

21 J- Oh!

22 R- another part. I want to put in one thing and it doesn't it doesn't accept it,

23 and it takes another thing. So, I would like to see if there's a program

24 G- [overlapping] Choo-chooooo!

25 R- [overlapping] that I could go to.

From that point on, Rosa spoke almost entirely in Spanish, throwing a few English phrases in (see Like in line 20 in excerpt (3.d) above). To briefly comment on my Spanish level: while I often made grammatical mistakes or uttered awkward 
constructions (see Da igual para mí in excerpt (3.d): line 13 above) or sometimes

did not know a particular word for an idea I was trying to express (see las cosas que

tienen los, la, los caballos in line 6 in excerpt (3.e) below), my interactions with Rosa

throughout the interviews were not hampered by my speaking level. Rosa often

commented how happy she was that we could "platicar / chat":

\section{(3.e) Excerpt from Interview \#2:}

1 J-Sí. Pues, muchas gracias por hablar conmigo.

2 R- Oh!

3 J- Realmente es [overlapping]

4 R- [overlapping] [...]

5 J- No, es que, estoy aprendiendo mucho. Y, a veces, me siento que... que

6 tengo... OK. ¿Sabe las cosas que tienen los, la, los caballos? ¿Que los ponen

7 esas cosas así? [mimes putting on blinders]

8 R- Oh, ¿para no ver...?

9 J- Para que no vean nada más de, de que los que está en frente de uno. Yo me

10 siento que tengo estos a veces. Realmente no sé qué está pasando alrededor

11 de mí. Pues, a través de hablar con usted, realmente estoy aprendiendo

12 mucho de, del mundo, de cómo es, a través de sus ojos, pues, es realmente un

13 honor hablar con usted. Pues, gracias.

14 R- No, pues. Aquí estoy, nomás poniendo [...] [laughs]

15 J- [laughs]

16 R- $\mathrm{Y}$ a veces hace falta convivir, platicar, que yo estoy en la casa, y tengo tres

17 personas más... [...]... y el papá de mi nuera es americano, la mamá es

18 americana, ella es americana, pero nunca están en la casa. Yo estoy todo el

día en la casa. No hay nadie. Todos se van a trabajar. Ellos llegan, yo me voy. Llego, están durmiendo. Se van ellos, estoy durmiendo. [laughs] So, no hay comunicación de nada. A veces tengo cosas que preguntar, pero... Agarro, me voy de viaje. Me voy con mi amiga, dos, tres días a Washington, y allí es donde platico mucho con ellas, y así y asá, y es, en [...] de mis amigas que yo tenía acá que ya no las tengo. So, sí tengo con quién platicar, y digo, ah! A veces los [...] pero, todos también están ocupadas, con su trabajo, y cosas de su familia, y no hay tiempo. Pues está bien de todas maneras, igracias! J- De nada, de nada.

$28 \mathrm{R}-\mathrm{Me}$, me gusta la manera que platicas, conversas, preguntas... Eres una

29 muchacha muy joven, y digo yo, ¿qué [...] de mí que estoy [...]?][laughs]

30 J- [laughs] ¡No, no no no no! No, no.

31 R- [laughs] Pero, está bien, [...] la manera [...]

32 J- Gracias. Quiero seguir aprendiendo. Quiero seguir desarrollando... ¿desa?

33 R- Desarrollando. 
J- Desarrollando, sí. Es... siempre quiero hacer eso.

35 R- Es bueno descubrir cosas que, quizás, ciertas personas lo tienen y uno no

lo sabe, o quizás, está uno equivocado y con esas personas se corrige uno, así pasa. Es bueno.

\section{(3.e) GLOSSED Excerpt from Interview \#2:}

1 J- Yes. Well, thank you so much for speaking with me.

$2 \mathrm{R}-\mathrm{Oh}$ !

3 J- It really is [overlapping]

4 R- [overlapping] [...]

5 J- No, it's that, I'm learning a lot. And, sometimes, I feel like... like I have... OK.

6 Do you know the things that horses have? Those things they put on them like

7 this? [mimes putting on blinders]

8 R- Oh, to not see?

9 J-So they don't see anything more than, than what's right in front of them. I

10 feel like I have those sometimes. I don't know what's really happening around me. So, through speaking with you, I really am learning a lot about the world, of how it is, through your eyes, so, it's really an honor to speak with you. So, thank you.

14 R- No, well. Here I am, only putting [...] [laughs]

15 J- [laughs]

R-And sometimes I miss socializing, chatting, because I'm in the house all day, and I have three more people [...]... and my daughter-in-law's father is American, her mom is American, she's American, but they're never in the house. I'm in the house all day. There's nobody. Everybody leaves for work. They arrive, I leave. I arrive, they're sleeping. They leave, I'm sleeping. [laughs] So, there isn't any kind of communication. Sometimes I have things I want to ask, but... I get myself together, I go on a trip. I go with my friend, two, three days to Washington, and there is where I chat a lot with them, and like this and like that, and it's, in [...] of my friends that I had here that I don't have any more. So, yes, I have someone to chat with, and I say, ah! Sometimes they [...] but, everyone is also busy, with their work, with family things, and there isn't time. So, anyways, it's good! Thanks! J- No worries, no worries. young woman, and I say, what [...] of me that I'm [...]? [laughs] J- [laughs] No, no no no no! No, no.

R- [laughs] But, it's good, [...] the way [...]

J- Thank you. I want to keep learning. I want to keep growing. Devel-? R- Developing. J- Developing, yes. It's... I always want to do that. know, or maybe, you're wrong and with those people you correct yourself, it happens like that. It's good. 
The interviews were semi-structured in the loosest sense; in order to delve into my guiding question, I brought questions covering the themes of how Rosa felt she had changed through taking ESL classes at this institution and who she saw herself as changing into (Norton, 2000), what communities of practice she participated in that may have had an influence on her language learning (Wenger, 1998) and how she viewed the classroom space (Lefebvre, 1974/1991 and Soja, 1989; 1996, as cited in Allen, 1999) and her interactions within the classroom itself (see Appendix A for an initial interview guide). Although I was interested in these topics and I had questions prepared to help prompt Rosa to discuss the complex issues I was interested in, Rosa's responses guided the interviews more than my original agenda. As the interviews progressed, they became more ethnographic in nature: I drew on previous points that Rosa had made in order to approach them from different angles and be able to analyze the iterations of her responses as I sought to understand how her identity, communities of practice, agency, and her conceptualization of the classroom space interacted.

To explore the idea of the student in the classroom space, my interview questions were also guided by my observations of Rosa's actions in her Intermediate-Low class.

In-class observations. During the Fall 2013 term, I attended the Intermediate-Low ESOL class that Rosa was enrolled in once a week for eight weeks. PSU's IRB required that I act as a "non-participant observer" (Cowie, 2009, p. 167) in these classes in order to limit coercion and maintain a clear line between my 
current role as a researcher and my previous role as the students' teacher. During each class that I observed, I sat in the back and took field notes. My field notes were divided into two parts: a description column and an interpretation column. My description column consisted of general descriptions of the classroom setting: the seating arrangements, the classroom routines, the number of students present, etc., while maintaining a specific focus on Rosa's actions. I kept a tally of how many times Rosa volunteered a response when the teacher was eliciting information from students, I described Rosa's behaviors when interacting with her peers, and I noted her general demeanor throughout various parts of the class periods (how she appeared more animated during break time, etc.). In my interpretation column, I noted initial interpretations of what I was seeing along with things I wished to question Rosa about during follow-up interview times. After each class, I highlighted themes that I felt might be related to Rosa's agency and identity and prepared a few guiding questions for the upcoming interview.

During our first research-related meeting on October $4^{\text {th }}, 2013$, Rosa and I discussed my role in the observations: in order to not lead the other students to suspect that Rosa was the focus of my research project, we agreed that I wouldn't seek her out, greet her in front of the other students, or otherwise indicate that I knew Rosa. Occasionally during class breaks, I ran into Rosa in the hallways or bathrooms, and we would exchange a few words. Since I was the rather unexpected guest who lurked in the back of the classroom, several of the other students seemed intrigued by my presence, and would often approach me during class breaks to ask me about my background and interest in their class (I simply told them I was an MA 
student interested in becoming a better teacher), so my brief interactions with Rosa during the class breaks were not out-of-pattern with my interactions with the other students in the class.

I had approached Rosa's teacher explaining that I was conducting interviews with one of her students (see Appendix C for the email script I sent the teacher), so while the teacher was fully aware that I was conducting a study, the teacher did not appear to know which of her students was my participant.

Rosa attended every class period that I observed; for the first few weeks that I was observing, I called her and let her know which days I would be coming, so as to not startle her if she came to class and unexpectedly saw me there. After the first few weeks, Rosa told me she appreciated having me in class because she believed that the teacher taught better when I was there:

(3.f) Excerpt from Interview \#1:

1 J- Pero ¿molesta usted si yo estoy en la clase? Como, ¿es una distracción?

2 R- ¡No! No.

$3 \mathrm{~J}-i^{\mathrm{No}}$ ?

4 R- No.

5 J- OK. Qué bien. Yo me siento... que no, que no, que no tengo el derecho de 6 estar en la clase. Como...

7 R- No, no, sí está bien.

8 J- ¿Sí?

9 R- Sí está bien, porque... pues sí nos enseña la maestra más, más detallada.

10 Más calmada. Pero... sí se atranca ella. Como que... como que, [...] busca las

11 cosas más fáciles, y es más, más calmada. Pero cuando no, joooh! [laughs]

12 ¡Agárrate porque tienes que...sí!

(3.f) GLOSSED Excerpt from Interview \#1:

1 J- But does it bother you if I'm in the class? Like, is it a distraction?

2 R-No! No.

3 J- No?

4 R- No. 
5 J- OK. That's good. I feel... like I don't, like I don't, like I don't have the right to

6 be in class. Like...

7 R- No, no, it's really good.

8 J-Yeah?

9 R- It's really good, because... well the teacher does teach us more, more in-

10 depth. More calmly. But, she does get blocked up. Like... like, [...] she looks

11 for the easiest things, and she's more, more calm. But when she isn't, oooh!

12 [laughs] Hold on because you've got to... yeah!

I followed up on this topic of the teacher acting differently when I was in class several times throughout subsequent interviews, and each time, Rosa said similar things, that the teacher taught more slowly when there were observers, and when there weren't, the teacher put more pressure on the class to move quickly. Because I, of course, wasn't there to observe on the days when there were no observers, I can't comment on how representative my weekly observations were of the class as a whole. However, because my observations were focused on Rosa's actions-not the teacher's actions-and because the purpose of the observations was to inform and shape my interviews with Rosa, I believe that the observations I completed were sufficient for me to put together a picture of Rosa's in-class participation, especially on days when she felt the most comfortable and able to participate because the teacher was teaching more slowly.

The Intermediate-Low class was held on Tuesdays, Thursdays, and Fridays, and for the first few weeks, I observed on Thursdays because the class spent some time in the institution's computer lab, and I wanted to see how Rosa interacted with concepts of digital literacy. Later in the term, I observed on different days of the week, occasionally coming on Tuesdays or on Fridays, in order to see if I could note any differences on different class days. 
Initially for triangulation purposes, I chose to conduct observations in the hope of both informing my interviews and my subsequent data analysis. Altogether, I have 24 hours of observation recorded in field notes. While the in-class observations were invaluable in helping me shape my interview questions and understand Rosa's reporting on her in-class actions, in the process of analyzing the data, it became clear that it was not necessary for me to draw heavily from this data to conduct a complete and thorough analysis. Therefore, I only use one episode that I recorded in my field notes during one class period to illustrate my analysis (see Chapter 1: Introuction); no other information will be provided about the observations in the rest of this thesis.

\section{Data Analysis Procedures}

I chose to use tools from grounded theory (Strauss \& Corbin, 1990, as described by Charmaz, 2006 and LaRossa, 2005) in order to analyze my data. Grounded theory methods are a "valuable set of procedures for thinking theoretically about textual materials" (LaRossa, 2005, p. 838) that allow a researcher to ask abstract questions about themes that emerge from a set of textual data, and then explore relationships between the different emergent categories, or variables. Grounded theory provides tools that are necessary and sufficient for an exploratory study such as this: when trying to ask broad questions about what is going on in an individual learner's life, it would be inappropriate to apply a pre-set theoretical framework. In wishing to fully explore Rosa's reports of her investment, identity, the social context of her life, and the classroom space, I needed the broad and creative explanatory potential that grounded theory offers. Specifically, I used 
descriptive and axial coding in order to explore relationships between topics that became salient during my analysis of my interview data.

The data analysis process was iterative and non-linear. Throughout the data collection process, I analyzed data in order to make subsequent data collection decisions and guide the "data analysis spiral" (Perry, 2011, p. 161), which specifically meant that I used the preliminary, descriptive codes that emerged from the first three interviews to identify developing themes and to then explore those themes in the subsequent interview.

I kept a series of analytic memos (Charmaz, 2006) asking myself questions along the way, pointing out holes in my analysis that I still needed to fill, and noting how my coding categories were shifting throughout the course of the study (for example, noting how it was necessary to expand certain categories to have a wider range, such as shifting my children and grandchildren to family / living situation; see longer discussion below).

Transcription and descriptive coding. I transcribed Interviews \#1-3 from December, 2013 - February, 2014. Because the interviews had been conducted in noisy locations with a lot of background noise (the interviews conducted in a McDonald's PlayPlace had many shrieking children that overlapped with and drowned out Rosa's speech), I ran Interviews \#2 and \#3 through Audacity (a free, open source, cross-platform software for recording and editing sounds available from http://audacity.sourceforge.net/), leveling the noise and reducing playback speed in order to ensure the accuracy of my transcriptions. I listened to each interview 4-6 times and edited my transcripts each time I listened. 
From February - March, 2014, I gave initial descriptive codes to the data using color-coded memos, keeping a spreadsheet of every instance of a particular code in each transcript. The initial codes were a mix of in-vivo codes (such as necesito mucha ayuda / I need a lot of help) and labels that I attached (such as what I do in class). I adjusted only a few codes as I went along (for example, expanding my children and grandchildren to family / living situation) and I made notes when I saw some overlap between certain quotes that I'd initially thought fit into one code versus another (for example, I originally had a code fuzzily called, what I want (from class?), and there were several instances of overlap with the code teacher, so I noted it in order to see what emerged in the later interviews).

After I coded Interview \#1, 14 descriptive codes emerged, and I used that descriptive coding scheme to code Interview \#2. A few codes shifted: estoy mal de mi vista / I have bad eyesight expanded to tuve un accidente / I had an accident (as Rosa's eyesight problems were mainly related to her car accident), and computer (which had been a salient theme in Interview \#1, but did not reappear again in Interviews \#2 or \#3) merged into what I want. Whenever a code shifted, I went back and re-coded all of the interviews to ensure a consistent coding scheme. I went through the same process for Interview \#3, ending up with 12 descriptive codes.

It was necessary to shift the boundaries on these codes (or to "fracture" and "reconstitute" them) because a key feature of grounded theory is that each code representing a concept needs to be instantiated in the data numerous times in order to be "theoretically saturated" (LaRossa, 2005, p. 846); in other words, there need to be numerous "indicators," which are quotes coded as belonging to a certain concept, 
within each code in order for the code to be useful and valid.

After all three interviews were descriptively coded, I attempted to put some of the codes together into categories for the purpose of checking my interpretations with a co-coder (see discussion of co-coder below). At this point, the categories were extremely rough (for example, I had a category called BARRIERS, meaning something that's keeping Rosa from being able to fully participate in class, which was made up of codes relating to legal/police issues, physical/health issues, lack of prior education, etc.; due to perceptive comments by the co-coder, this category and others were later re-organized into categories that, while still coming from my interpretations of Rosa's words, were more true to the data. To see the full tables of the initial rough categories, go to Appendix D).

Using these initial trends and impressions, I developed an interview guide for my fourth and final interview, which took place on March 1st, 2014, in a back corner of the same McDonald's that we'd met in earlier. During this interview, we explored themes of her changing family situation, her early years in the United States and her reasons for leaving Mexico, the reasons why she decided to leave her IntermediateMid English class, and her relationship to learning English. Each of these themes had become salient in the previous three interviews, and Rosa was very keen to continue discussing these topics as I brought them up during the fourth interview. It was during this fourth interview that I was able to circle back and confirm my interpretations of many issues that we had discussed during previous interviews, and it was during the fourth interview that the following exchange occurred:

(3.g) Excerpt from Interview \#4: 
1 R- Así es mi historia con el inglés.

2 J-Sí, sí. Pero inglés es solamente una parte muy pequeña, ¿no? de su vida.

3 Pues, no sé. ¿Cuáles... si usted pudiera decir "esas son las partes más

4 importantes de mi vida," ¿qué sería? ... Ser madre, ser madre, ser abuela, ser

5 trabajadora... no sé. ¿Qué diría usted?

6 R- Ah... La parte más importante de mi vida, yo creo que... sería saber inglés.

(3.g) GLOSSED Excerpt from Interview \#4:

1 R- That's my story with English.

2 J- Yes, yes. But English is only a small part of your life, right? Well, I don't

3 know. What... if you could say, "these are the most important parts of my

4 life," what would they be? ... Being a mother, being a grandmother, being a

5 worker... I don't know. What would you say?

6 R- Ah... The most important part of my life, I think ... would be to know

7 English.

This statement later became one of the crucial foci of my analysis. Rosa declared many, many times that she needed to learn, she was going to learn, she wanted to "eat English up" (excerpt (3.b) above).

However, I had formulated my guiding question (asking about her investment in participating in a community ESL program) with a particular interest in wondering what she was doing inside the classroom, so during my initial descriptive analyses, I coded Rosa's statement above as what I want and only made a memo to myself that “yes! my thesis is worthwhile." It wasn't until later, during the phase of axial coding (see description of axial coding process below) that I returned to place this statement at the heart of my analysis (see Chapter 4).

After completing the above steps in the data analysis process, I had four transcribed interviews and a descriptive coding scheme with 12 codes that had emerged from the interviews, and I had a rough initial sketch of trying to see how the codes fit together (see Appendix D). At this point, it was necessary to verify my 
initial interpretations with another qualitative researcher who was not as invested in the data as I was, and who could point out areas that I had missed.

Co-coding. In order to check my initial interpretations of the data, I enlisted the help of a bilingual, bicultural co-coder who identified as Latina. This co-coder had worked as a sociolinguistics research assistant and had conducted research in which she did qualitative analysis and coding. I sent the co-coder a packet that contained $12.5 \%$ of my total data across all four interviews. To create the packet, I ignored data I deemed "not relevant to the guiding question" (lengthy exchanges in which Rosa and I compared notes about our Christmas vacations, or tangential anecdotes that I was telling Rosa as a part of our conversation flow that would have been useless for the co-coder to read). Across all four interviews, $78 \%$ of the data was relevant to the research question. For each set of relevant interview data, I chose a random word (by inserting the word count of the interview into random.org, generating a random number, and selecting the word in the relevant interview data that corresponded to that word-count number) and then chose a block of text surrounding that word forming a coherent passage. Each passage contained $10-15 \%$ (as determined by word count) of the total interview data, averaging out to $12.5 \%$ of my total data across all four interviews.

After extracting the passages from each interview, I sent them to the cocoder along with a list of instructions: I wanted her to read the raw (un-coded, unannotated) passages before reading the coded and annotated versions (see Figure 1). I asked her to read what I had written in my comments and to point out any areas that she disagreed with. In the packet, I also sent her the two charts shown in 
Appendix D, and asked her to make any general comments about the rough categories. We agreed to meet for 1.5 hours to discuss the areas in which we disagreed.

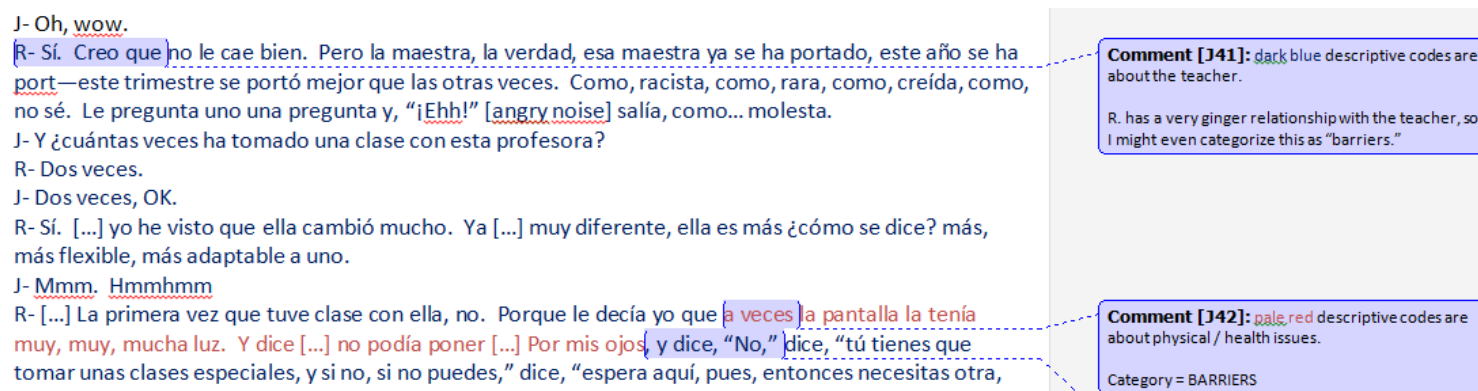
Comment [341]: dark blue descriptive codes are about the teacher.

R. has a very ginger relationship with the teacher, so I might even categorize this as "barriers."

Figure 1: Excerpt of coded and annotated data sent to co-coder.

I found the co-coder's help invaluable in interpreting my data; we had $87 \%$ agreement on coding, which gave me confidence that my coding scheme was not completely off the mark, and after discussing the $13 \%$ of the data that she disagreed with me on, I decided to adjust my coding scheme to fit her suggestions. I had originally grouped together many topics relating to her English-language-learning experiences under the code what I do in class / what happens in class, which the cocoder pointed out should probably be much more fine-grained, considering that what she does in class is central to my guiding question. I agreed that I should take a much closer view of different aspects that I later grouped into the category of "Relationship to Learning English" (see Table 1 below). In addition, because of her bicultural background, the co-coder was able to point out areas that I had originally interpreted too broadly. For example, I had originally coded most of the following exchange, in which Rosa describes not having gotten an original birth certificate, as legal/police issues:

(3.h) Excerpt from Interview \#1: 
$1 \quad$ J- ¿De qué parte en Mex, en México es usted?

2 R- Pues, ¿cómo te voy a decir? Sincera, sincera, sincera, de los ojos [...] [G is

3 shouting] no puedo mentir ni te puedo decir "o soy de aquí o soy de allá." No

4 sé de dónde soy. Porque mi mamá no me puso, no me registró... nací en el DF,

5 según ella, en México en el Distrito Federal. Pero, no tengo una acta para

6 decir, "Soy... soy mexicana," "Soy oaxaqueña," "Soy veracruzana," "Soy

7 hondureña" "Soy..." Yo no tengo acta. Yo he pasado... muy duro con la [...]

8 con la vida, me ha tratado de [...], pero aquí estoy, y sigo adelante. [...]

9 J- Aha.

10 R- Como amigas, te confío. Pero yo no tengo nacionalidad.

\section{(3.h) Excerpt from Interview \#1:}

1 J- From what part in Mex, in Mexico are you?

2 R- Well, how can I tell you? Sincerely, sincerely, from my eyes [...] [G is

3 shouting] I can't lie to you and I can't say, "I'm from here or I'm from there." I

4 don't know where I'm from. Because my mom didn't put me, didn't register

5 me... I was born in Mexico City, according to her, in Mexico, in the capital.

6 But, I don't have a birth certificate to say, "I'm... I'm Mexican," "I'm Oaxacan,"

7 "I'm from Veracruz," "I'm Honduran," "I'm..." I don't have a birth certificate.

8 It's been... really hard with the [...] with life, I've tried to [...], but here I am,

9 and I'm going to keep going. [...]

10 J- Aha.

11 R- As friends, I trust you. But I don't have a nationality.

However, the co-coder pointed out the poignancy and the emotion with

which Rosa described her lack of a birth certificate, and she told me that, as a fellow Latina, she believed Rosa was placing a much higher value on her birth certificate than I had originally assumed; the co-coder suggested that I view Rosa's statement of "yo no tengo nacionalidad / I don't have a nationality" to be a strong statement of identity rather than simply legal/police issues. After discussing this passage with the co-coder, I agreed with her, and re-coded this and other sections in which Rosa made strong statements about who she was or was not.

Revised descriptive codes. After working with the co-coder, I re-worked the coding scheme to include 21 descriptive codes. In addition, after many 
discussions with my adviser, I changed one code from sobresalir / sobrellevar las cosas / así es la vida / LIFE OUTLOOK to no me voy a dejar / AGENCY. The original code of "life outlook" related to statements of Rosa's like "así es la vida / such is life," and my interpretation was that Rosa had an overly fatalistic view of her life. My adviser pointed out that my interpretation of her words was erring on the side of judgement and evaluation, instead of representing Rosa as she represented herself, and we decided that a more accurate code for statements about how Rosa perceived her life and her ability to act in her life as no me voy a dejar / AGENCY.

After re-coding all of the data with the final 21 descriptive codes (see coding table below), I began to re-group the codes into more balanced categories that were better dimensionalized. Examining categories in terms of the properties of the category, or dimensionalizing, is a crucial step in developing categories (Strauss, 1987, as cited by LaRossa, 2005); a dimensionalized category is one in which "putatively dissimilar but still allied" (LaRossa, 2005, p. 843) concepts are grouped together, and the concepts are examined to ensure that they adjoin but do not overlap. It wasn't until after I had begun to group the codes together again and ask questions about how codes were associated with one another, that I realized the codes fit naturally into categories that somewhat mirrored my guiding question (How do adult ESL students report that their identities, the social contexts of their lives in the United States, and the classroom space shape their investment in participating in community ESL programs?). The only category that ended up being different than the guiding question was a category that I ended up calling “relationship to learning English.” When I'd originally formulated my guiding 
question, I was merely interested in her participation in the particular classroom I

was observing, but her relationship to learning English was far wider-reaching than

the classroom walls, and I realized that I had unnecessarily limited my focus.

The following table illustrates my final descriptive coding schema:

\begin{tabular}{|c|c|c|}
\hline \multicolumn{3}{|c|}{ MAJOR CATEGORY: SOCIAL CONTEXT OF HER LIFE } \\
\hline IN VIVO CODE & $\begin{array}{c}\text { DESCRIPTIVE QUOTE } \\
/ \\
\text { GLOSS }\end{array}$ & $\begin{array}{l}\text { ENGLISH } \\
\text { MEMO }\end{array}$ \\
\hline $\begin{array}{l}\text { yo fui padre y } \\
\text { madre para mis } \\
\text { hijos }\end{array}$ & $\begin{array}{l}\text { Y no sé hablar inglés, porque yo fui padre y madre para mis } \\
\text { hijos. Yo tuve tres hijos, y yo trabajaba dos trabajos, y yo } \\
\text { no tuve tiempo para ir a la escuela } \\
\text { I don't know how to speak English, because I was both } \\
\text { father and mother for my children. I had three children, and } \\
\text { I worked two jobs, and I didn't have time to go to school }\end{array}$ & FAMILY \\
\hline trabajando & $\begin{array}{l}\text { Y la mayoría de nosotros tenemos trabajo. Y como, pues yo } \\
\text { no trabajo, pero hay veces que sí trabajo, voy a hacer } \\
\text { limpieza de otras casas, tengo que hacer todo que es una } \\
\text { casa. } \\
\text { And most of us have Jobs. And like, well I don't work } \\
\text { [regularly], but sometimes I do work, I go to clean other } \\
\text { houses, I have to do everything to keep house. }\end{array}$ & WORK \\
\hline $\begin{array}{l}\text { yo estoy mal de } \\
\text { mi vista / tuve } \\
\text { un accidente }\end{array}$ & $\begin{array}{l}\text { como tuve un accidente, y mi cabeza siento que se va a } \\
\text { [mimes exploding], and no quiero estar quebrando mi } \\
\text { cabeza... } \\
\text { Because I had an accident, and I feel like my head is going } \\
\text { to [mimes exploding], and I don't want to be breaking my } \\
\text { head... }\end{array}$ & $\begin{array}{l}\text { PHYSICAL } \\
\text { BARRIERS AND } \\
\text { DIFFICULTIES }\end{array}$ \\
\hline la ley & $\begin{array}{l}\text { el policía: muy racista, muy racista, muy racista. } \\
\text { the policeman: very racist, very racist, very racist. }\end{array}$ & $\begin{array}{l}\text { LEGAL/POLICE } \\
\text { ISSUES }\end{array}$ \\
\hline $\begin{array}{l}\text { tengo treinta } \\
\text { años en } \\
\text { Estados Unidos. }\end{array}$ & $\begin{array}{l}\text { Oh, man. Yo estoy media loca. Ay, Dios mío, digo. Pero me } \\
\text { gusta Estados Unidos. Una parte no me gusta con muchas } \\
\text { cosas, que vea uno muchas cosas ocultas que hacen, pero en } \\
\text { México, hacen peor también [laughs]. } \\
\text { Oh, man. I'm half crazy. Oh my God, I say. But I like the US. } \\
\text { One part that I don't like with a lot of things, that you see a } \\
\text { lot of hidden things that people do, but in Mexico, they do } \\
\text { even worse things [laughs]. }\end{array}$ & $\begin{array}{l}\text { US (NON-LEGAL, } \\
\text { NON-SOCIAL) }\end{array}$ \\
\hline en México & $\begin{array}{l}\text { Hay áreas dónde no se da nada. No hay ni agua. Es bien } \\
\text { pobre. Pero hay áreas dónde está muy bonito. Hay mucha } \\
\text { agua, hay pesca, hay ganado, dónde ordeñan, sacan queso, }\end{array}$ & MEXICO \\
\hline
\end{tabular}




\begin{tabular}{|c|c|c|}
\hline & $\begin{array}{l}\text { tienen carne, tienen puercos, tienen pollos, tienen todo. No } \\
\text { hay problema. } \\
\text { There are areas where the land doesn't give anything. } \\
\text { There isn't even water. It's really poor. But there are areas } \\
\text { where it's really pretty. There's a lot of water, there's } \\
\text { fishing, there's cattle, there are places where they milk } \\
\text { cows, make cheese, they have beef, they have pigs, they } \\
\text { have chickens, they have everything. There's not a } \\
\text { problem. }\end{array}$ & \\
\hline $\begin{array}{l}\text { Tengo muchos } \\
\text { amigos aquí. }\end{array}$ & $\begin{array}{l}\text { Tengo muchos amigos aquí. } \\
\text { I have a lot of friends here. }\end{array}$ & $\begin{array}{l}\text { SOCIAL LIFE (IN } \\
\text { THE US; OUT OF } \\
\text { CLASS) }\end{array}$ \\
\hline $\begin{array}{l}\text { estás en la } \\
\text { calle con unas } \\
\text { personas } \\
\text { burlescas }\end{array}$ & $\begin{array}{l}\text { Porque a veces estás en la calle con unas personas } \\
\text { burlescas—que, que ellos no entienden que tú no eres de } \\
\text { aquí-y se burlan de ti como tú hablas el inglés. } \\
\text { Because sometimes you're in the street with people who } \\
\text { make fun of you—that, they don't understand that you're } \\
\text { not from here-and they make fun of you, of how you speak } \\
\text { English. }\end{array}$ & $\begin{array}{l}\text { INTERACTING } \\
\text { W/ STRANGERS } \\
\text { IN THE US } \\
\text { OUTSIDE THE } \\
\text { CLASSROOM }\end{array}$ \\
\hline $\begin{array}{l}\text { Un ciego no } \\
\text { puede dirigir a } \\
\text { otro ciego. / yo } \\
\text { soy la } \\
\text { persona...más } \\
\text { burra }\end{array}$ & $\begin{array}{l}\text { Y si tú no estudiastes... sí, por ejemplo yo no estudié. } \\
\text { ¡Muchas palabras y no sé qué significan en español! Ni lo sé } \\
\text { escribir tampoco. Y digo yo, digo yo, yo no puedo entender. } \\
\text { And if you didn't go to school... yes, for example, I didn't go } \\
\text { to school. I don't know what a lot of words mean in } \\
\text { Spanish! I don't know how to write it, either. And I say, I } \\
\text { say, I can't understand. }\end{array}$ & $\begin{array}{l}\text { LACK OF PRIOR } \\
\text { EDUCATION }\end{array}$ \\
\hline \multicolumn{3}{|c|}{ MAJOR CATEGORY: IDENTITY } \\
\hline IN VIVO CODE & DESCRIPTIVE QUOTE & ENGLISH MEMO \\
\hline $\begin{array}{l}\text { no me voy a } \\
\text { dejar }\end{array}$ & $\begin{array}{l}\text { Y digo yo... pero si no... ya no me quieren a ir, voy a buscar } \\
\text { otro lado. No me voy a dejar. [laughs] } \\
\text { And I say...but if they don't...if they don't want me to come } \\
\text { any more, I'm going to look for another place. I'm not going } \\
\text { to let them do that to me [laughs]. }\end{array}$ & AGENCY \\
\hline yo soy & $\begin{array}{l}\text { tú sabes que uno es como Dios ya lo, lo trajo al mundo } \\
\text { you know that you are [the same] as God brought you into } \\
\text { the world. }\end{array}$ & IDENTITY \\
\hline \multicolumn{3}{|c|}{ MAJOR CATEGORY: SCHOOL SPACE } \\
\hline IN VIVO CODE & DESCRIPTIVE QUOTE & ENGLISH MEMO \\
\hline esa escuela & $\begin{array}{l}\text { tienes que ir a disability, y quien sabe que, se necesita } \\
\text { disability, no no estaba, fui, dejé los papeles, no me los-no } \\
\text { los pusieron en la computadora, so yo me no [...]. Dije, yo } \\
\text { ya no voy a ir, mejor voy a seguir como soy. } \\
\text { you have to go to disability, and I don't know what, you } \\
\text { need [the] disability [office], nobody was there, I went, I left }\end{array}$ & $\begin{array}{l}\text { THE } \\
\text { INSTITUTION }\end{array}$ \\
\hline
\end{tabular}




\begin{tabular}{|c|c|c|}
\hline & $\begin{array}{l}\text { my papers, they didn't-they didn't put them in the } \\
\text { computer, so I didn't [...]. I said, I'm not going to go [back to } \\
\text { that office] any more; it's better that I continue as I am. }\end{array}$ & \\
\hline $\begin{array}{l}\text { ustedes / esa } \\
\text { maestra }\end{array}$ & $\begin{array}{l}\text { A los maestros no les importa haber muchos estudiantes, y } \\
\text { para ellos tienen trabajo all the time } \\
\text { The teachers don't care if they have a lot of students, and } \\
\text { for them they have work all the time }\end{array}$ & $\begin{array}{l}\text { TEACHERS IN } \\
\text { GENERAL }\end{array}$ \\
\hline $\begin{array}{l}\text { habemos } \\
\text { muchos } \\
\text { estudiantes }\end{array}$ & $\begin{array}{l}\text { habemos muchos estudiantes que necesitamos más } \\
\text { ayuda y habemos muchos que, que ya estamos entre el } \\
\text { programa, y habemos muchos que no vamos por la misma } \\
\text { razón. Se asustan. Se espantan. Dicen no, pues sí, lo que tá } \\
\text { enseñando yo no puedo entender - so, mejor, dejan de ir a } \\
\text { la escuela. Y eso no está bien para, pa la persona, para uno } \\
\text { mismo. } \\
\text { we are a lot of students who need a lot of help and we are } \\
\text { many who are already in the program, and a lot of us don't } \\
\text { go for the same reason. We get scared. We get frightened. } \\
\text { We say, "No, what she's teaching, I can't understand.” So, } \\
\text { usually, we leave school. And that's not good for a person, } \\
\text { for yourself. }\end{array}$ & $\begin{array}{l}\text { OTHER } \\
\text { STUDENTS IN } \\
\text { THE CLASS = } \\
\text { SOCIAL } \\
\text { INTERACTIONS } \\
\text { IN THE CLASS }\end{array}$ \\
\hline $\begin{array}{l}\text { todo que dictó } \\
\text { ella lo } \\
\text { escribimos }\end{array}$ & $\begin{array}{l}\text { Como ayer, es que vio que, la primera cosa que hicimos es, } \\
\text { la, ¿cómo se dice? dictation. Nos dictó ella cosas y, diciendo, } \\
\text { y es que, ciertas cosas diciendo. Ya de allí, todo que dictó } \\
\text { ella lo escribimos. } \\
\text { Like yesterday, it seemed that, the first thing we did is. the, } \\
\text { how do you say it? Dictation. She dictated things to us and, } \\
\text { saying, and it's that, saying certain things. And from there, } \\
\text { everything she dictated we wrote down. }\end{array}$ & $\begin{array}{l}\text { WHAT HAPPENS } \\
\text { IN CLASS }\end{array}$ \\
\hline $\begin{array}{l}\text { Me voy, me } \\
\text { siento, y allí } \\
\text { estoy }\end{array}$ & $\begin{array}{l}\text { Y ok, dije yo, ya por eso ahorita ya casi mejor no hablo. } \\
\text { Mejor no más estoy escuchando, escuchando, escuchando, y } \\
\text { por lo rest, no [...] preguntas, pues sí. } \\
\text { And OK, I said, because of that for now perhaps I almost } \\
\text { don't speak. I'd better just listen, listen, listen, and for the } \\
\text { rest, no [...] questions, so yeah. }\end{array}$ & $\begin{array}{l}\text { I JUST SIT THERE } \\
=\text { WHAT I DO IN } \\
\text { CLASS } \\
\text { (AGENTIVE) }\end{array}$ \\
\hline \multicolumn{3}{|c|}{ MAJOR CATEGORY: RELATIONSHIP TO LEARNING ENGLISH } \\
\hline IN VIVO CODE & DESCRIPTIVE QUOTE & ENGLISH MEMO \\
\hline $\begin{array}{l}\text { Es muy difícil el } \\
\text { inglés }\end{array}$ & $\begin{array}{l}\text { Y me dice, "You know what?" Y dice, "I don't know, pero tu } \\
\text { inglés no tá mejorando!” [Laughs] } \\
\text { And he tells me, "You know what?" and he says, “I don't } \\
\text { know, but your English isn't getting better!” [Laughs] }\end{array}$ & $\begin{array}{l}\text { ENGLISH IS } \\
\text { HARD }\end{array}$ \\
\hline $\begin{array}{l}\text { yo quiero } \\
\text { estudiar / estoy } \\
\text { tratando de } \\
\text { aprender inglés }\end{array}$ & $\begin{array}{l}\text { Eso lo que voy a pensar es, si ya soy viejita y voy con un } \\
\text { bastón, voy a seguir estudiando. [laugh] iSí! Voy a seguir } \\
\text { estudiando. Voy a seguir estudiando que es el estudio, } \\
\text { porque no lo sé, y no supe, pero voy a saber. Quiero saber. } \\
\text { What I'm thinking is, when I'm old and walk with a stick, } \\
\text { I'm going to keep learning. [laugh] Yes! I'm going to keep }\end{array}$ & $\begin{array}{l}\text { I'M TRYING TO } \\
\text { LEARN / I WANT } \\
\text { TO LEARN } \\
\text { ENGLISH }\end{array}$ \\
\hline
\end{tabular}




\begin{tabular}{|c|c|c|}
\hline & $\begin{array}{l}\text { learning. I'm going to keep learning what it is to learn, } \\
\text { because I don't know, I never knew, but I'm going to know. } \\
\text { I want to know. }\end{array}$ & \\
\hline $\begin{array}{l}\text { quiero saber el } \\
\text { inglés pa } \\
\text { saber...cosas } \\
\text { para que otra } \\
\text { gente no me } \\
\text { engañe }\end{array}$ & $\begin{array}{l}\text { Simplemente lo quiero para uso personal. Para ayudar a } \\
\text { alguien cuando lo necesita, o para entender realmente que } \\
\text { esa persona está tratando de decir. Nomás para eso. Yo } \\
\text { no... yo no quiero, oh, porque, “iYa sé inglés! Y me voy a ir a } \\
\text { México, voy a ser una profesora de preparatoria, de } \\
\text { bachillerato." Whatever. Como, just, nomás quiero saber el } \\
\text { inglés pa saber que yo estuve aquí en Estados Unidos, y que } \\
\text { yo sé cosas para que otra gente no me engañe. } \\
\qquad \\
\text { I simply want it for my personal use. To help someone } \\
\text { when they need it, or to really understand what that person } \\
\text { is trying to say. Only for that. I don't... I don't want, oh, } \\
\text { because “Now I know English! And I'm going to go to } \\
\text { Mexico, I'm going to be an elementary school teacher, a } \\
\text { high school teacher.” Whatever. Like, just, I only want to } \\
\text { know English to know that I was here in the united States, } \\
\text { and that I know some things so other people don't deceive } \\
\text { me. }\end{array}$ & $\begin{array}{l}\text { WHY I WANT TO } \\
\text { LEARN }\end{array}$ \\
\hline práctica & $\begin{array}{l}\text { Pero, la falta de práctica, la falta de repetición. Eso es el } \\
\text { problema. } \\
\text { But, the lack of practice, the lack of repetition. That's the } \\
\text { problem. }\end{array}$ & $\begin{array}{l}\text { HOW I WANT / } \\
\text { NEED TO LEARN } \\
\text { (LEARNING } \\
\text { STRATEGIES) }\end{array}$ \\
\hline $\begin{array}{l}\text { lo puede uno } \\
\text { pronunciar } \\
\text { bien }\end{array}$ & $\begin{array}{l}\text { Como ayer, no podía pronunciar... no sé qué no podía } \\
\text { pronunciar. Y al último escuché pero entre muchos, no sé } \\
\text { [laughs]. No sé, ni supe, ni sabré. [laughs] } \\
\text { Like yesterday, I couldn't pronounce... I don't know what I } \\
\text { couldn't pronounce. And finally I heard but among other } \\
\text { things, I don't know [laughs]. I don't know, I never knew, } \\
\text { nor will I ever know. [laughs] }\end{array}$ & PRONUNCIATION \\
\hline
\end{tabular}

Axial coding. After determining the above descriptive coding schema, the next step in the grounded theory process that I chose to use was to create axial codes, in which "[t]he focal category or variable is temporarily placed at the hub of the analysis and the when, where, why, and so on constitute the spokes around the hub" (LaRossa, 2005, p. 847, emphasis in the original). Specifically, I chose to use Glaser's “six C's” as a line of inquiry (looking for the causes, contexts, contingencies, consequences, covariances and conditions around 
a focal category, 1978, as cited by LaRossa, 2005). The "six C's" afforded me the ability to focus on how each of the major categories that arose from the descriptive coding (identity/agency, social context of her life, school space, and relationship to learning English) related to one another.

I originally placed the descriptive code me voy, me siento, y allí estoy / IJUST SIT THERE = WHAT I DO IN CLASS (AGENTIVE) at the center of the "hub" to stay true to my narrow guiding question of how the different variables affect her participation in class. However, arranging the codes only around what she did in class was unnecessarily limiting, because her desire to learn English is much broader, so I decided to re-focus my "hub" around two focal codes: me voy, me siento, y allí estoy / I JUST SIT THERE = WHAT I DO IN CLASS (AGENTIVE) and quiero saber el inglés pa saber...cosas para que otra gente no me engañe / WHY I WANT TO LEARN. The addition of this second code to the focal area of my axial coding allowed me to see how these two foci overlapped and differed; that is, where her desire to learn English coincided with what she reported doing in the classroom, and where that desire and her in-class actions diverged.

While arranging and re-arranging the two focal codes, I considered Glaser's "six C's" in how each of the descriptive codes related to the focal codes. Some codes were direct causes of or resulted in consequences for other codes: for example, when Rosa reported that her husband wouldn't let her attend English class, I arranged yo fui padre y madre para mis hijos / FAMILY as a cause of me voy, me siento, y allí estoy / I JUST SIT THERE = WHAT I DO IN CLASS (AGENTIVE). I then checked all of the indicators of yo fui padre y madre para mis hijos / FAMILY to ensure that all of the 
indicators also indexed a causal/consequential relationship between Rosa's relationship with her family and Rosa's participation in class. A few of the codes had contextual relationships: tengo trenta años en EE.UU. / US (NON-LEGAL, NONSOCIAL) provided the context for tengo muchos amigos aquí / SOCIAL LIFE IN THE US (OUT OF CLASS). In Figure 1 below, each of the black arrows shows either a causal, consequential, or contextual relationship.

In addition, I began to consider how the two codes related to Rosa's identity (yo soy / IDENTITY and no me voy a dejar / AGENCY) were central to many, but not all, of the other descriptive codes (see full discussion of findings in Chapter 4): I analyzed these codes as being conditions for the other codes. For example, Rosa expressed that her interactions with people in the US are a motivator for her to learn English. She often spoke of positive interactions and her happiness in getting to know other people, but there were negative encounters that served as spurs to her learning as well. Excerpt (3.i) below provides an example of axial coding

\section{(3.i) Excerpt from Interview \#1:}

1 R- Sé muchas cosas pero lo que pasa, muchas palabras no las sé. No las sé 2 juntar. No sé dónde-sí, más o menos donde van los verbos y eso. Quisiera 3 saber más de eso. Yo quisiera entender. Yo quisiera, como te diré pa [=para] 4 que... Porque a veces estás en la calle con unas personas burlescas-que, que 5 ellos no entienden que tú no eres de aquí-y se burlan de ti como tú hablas el 6 inglés. Y digo yo la regué pero, pues es que todo al tiempo no lo puedes hacer.

$7 \quad$ Tienes que ir paso por paso. Y digo yo, "Oh, es OK." No es la primera ni la 8 última persona. Hay muchas personas que tienen el mismo problema que yo, 9 pero voy a tratar de corregir mis, mis errores. [Laugh].

$10 \mathrm{~J}-\mathrm{Mmm}$ hmm. Pues, ¿Qué hace usted cuando está en la calle y una persona 11 está burlando?

12 R- Just, lo ignoro.

(3.i) GLOSSED Excerpt from Interview \#1: 
1 R- I know a lot of things but what happens is, I don't know a lot of words. I

2 don't know how to put them together. I don't know where-yes, more or less

3 I know where the verbs go and that. I would like to know more of that. I

4 would like to understand. I would like, how can I tell you so that... Because

5 sometimes you're in the street with people who make fun of you-that, that

6 they don't understand that you're not from here-and they make fun of how

7 you speak English. And I say I messed up, but, well you can't do it all at one

8 time. You have to go step by step. And I say, "Oh, it's OK." They're not the

9 first or the last person. There are a lot of people who have the same problem

10 as I do, but I'm going to try to correct my, my errors. [Laugh].

$11 \mathrm{~J}-\mathrm{Mmm}$ hmm. So, what do you do when you're in the street and somebody is

12 making fun of you?

13 R- I just ignore them.

This passage exemplifies several descriptive codes: the umbrella topic is “quiero saber el inglés pa saber...cosas para que otra gente no me engañe / WHY I WANT TO LEARN, with Rosa characterizing her negative interactions with people in the street (estás en la calle con unas personas burlescas / INTERACTING W/ STRANGERS IN THE US OUTSIDE THE CLASSROOM) being an impulse for wanting to learn better English. The specific thing Rosa commented that people made fun of her for was "how [she] speak[s] English," a theme that came up many times throughout the interviews and therefore necessitated the code lo puede uno pronunciar bien / PRONUNCIATION. Rosa's conclusion in this passage starting with "yo la regué / I messed up" in lines 5-6 (Spanish; line 7 English) and ending with "Just, lo ignoro / I just ignore them" in line 12 (Spanish; line 13 English) exemplifies an attitude that she expressed quite often that I coded as no me voy a dejar / AGENCY.

This code "agency" can be characterized as a condition (one of Glaser's six C's) surrounding Rosa's focus on her own poor (in her opinion) pronunciation, her interaction with strangers, and her desire to learn English. Through my analysis, the 
two central codes related to identity (yo soy / IDENTITY and no me voy a dejar /

$A G E N C Y$ ) emerged as conditions for a great number of the other descriptive codes;

some topics, like trabajando / WORK were very central to these central codes, while other topics such as lo puede uno pronunciar bien / PRONUNCIATION had a more peripheral role (see Figure 2 below).

After I considered the "six C's" around the two focal codes and around the two central codes of identity, the following figure emerged, with the two focal codes connected by Rosa's general desire to learn English (yo quiero estudiar / estoy tratando de aprender inglés / I'M TRYING TO LEARN / I WANT TO LEARN ENGLISH).

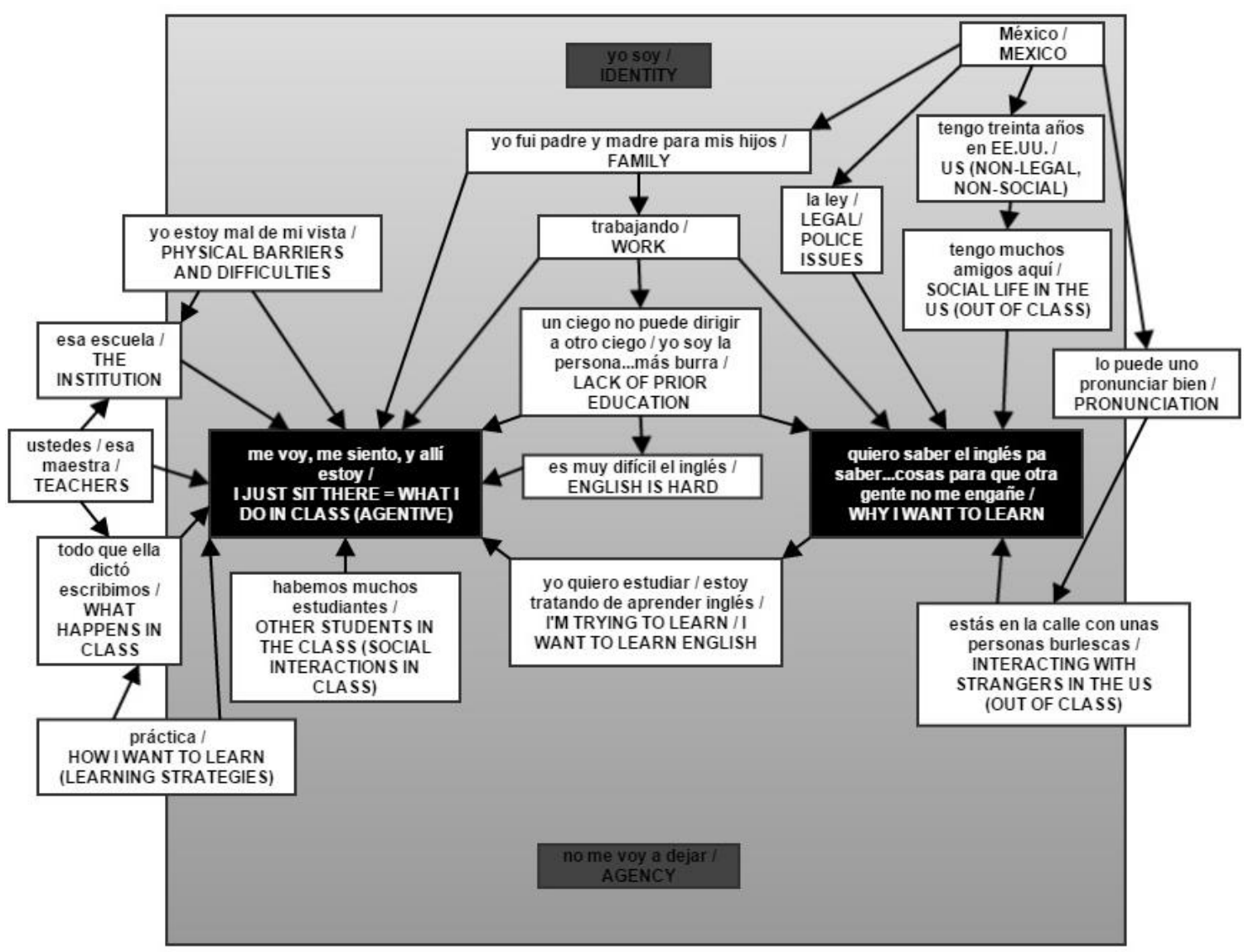

Figure 2. Axial coding of data. (Sacklin, 2015).

A brief explanation of this figure: The two focal codes of my study are me voy, 
me siento, $y$ allí estoy / I JUST SIT THERE = WHAT I DO IN CLASS (AGENTIVE) and quiero aprender el inglés pa saber... cosas para que otra gente no me engañe / WHY I WANT TO LEARN. These two focal codes appear in black in the figure above. They are connected by Rosa's general desire to learn English (yo quiero estudiar / estoy tratando de aprender inglés / I'M TRYING TO LEARN / I WANT TO LEARN ENGLISH).

All codes inside the large shaded box had indicators in the data which related directly to the conditions of yo soy / IDENTITY and no me voy a dejar / AGENCY (which appear in darker boxes at the top and bottom of the large shaded box). The codes that appear along the edges of the large shaded box did not have a strong connection to these two conditions in the data; specifically, codes that appear outside the shaded box had fewer than $25 \%$ of the indicators of that code that related directly to Rosa's identity or agency. For example, Rosa mentioned topics related to pronunciation eight times across the four interviews, and of those eight indicators in the data, only two showed where the conditions of identity and/or agency directly affected Rosa's expressing of her pronunciation. In contrast, Rosa mentioned topics related to work or employment 28 separate times throughout the four interviews, and 25 of those work-related indicators were directly tied to her identity and/or agency. Therefore, trabajando / WORK appears in a much more central position in the large shaded box than lo puede uno pronunciar bien / PRONUNCIATION. The codes that appear completely outside the large shaded box did not have any indicators in the data that were affected by the conditions of identity or agency.

The directional arrows show relationships between the codes in terms of 
causes, consequences, and contexts. For example, during the term when I was observing Rosa in class, she often had to leave class early in order to go to work (therefore, trabajando / WORK $\rightarrow$ me voy, me siento, y allí estoy / I JUST SIT THERE = WHAT I DO IN CLASS (AGENTIVE)).

An expanded set of principles adhering to grounded theory research would dictate that I take the following step of theoretical coding (Glaser, 1978, as cited by Charmaz, 2006) and then selective coding (Strauss \& Corbin, 1998, as cited by LaRossa, 2005). If this thesis were a PhD dissertation, I would go on to complete the above steps. However, a full grounded theory study is beyond the scope of this MA thesis, and I chose to end my analysis after determining the relationships of the salient categories to the two focal codes.

Having discussed the process of my data collection and analysis, I will now address the necessary demands of sound qualitative research that the researcher engender an ethical relationship with her informant and that she prove herself trustworthy.

\section{Ethical Issues and Trustworthiness}

Trustworthiness. Lincoln and Guba (1985) present four criteria for the trustworthiness of a research study: credibility, transferability, dependability, and confirmability. To establish credibility, I had prolonged engagement with my participant (five months as her teacher before the study started), persistent observation (three months of in-class observations in order to shape four 1-1.5hour long interviews over the course of five months), triangulation (in-class observations as well as interview data), member checking (after conducting and 
analyzing the first three interviews, I followed up on several themes with the participant during the fourth interview to confirm my analyses), and peer debriefing (while writing my research results, I discussed my research three times a week with a graduate student who has experience at the PhD level conducting qualitative research using grounded theory).

To establish transferability, I have chosen to use thick description of my experiences with Rosa, and I have chosen to allow Rosa's words to take up a significant portion of my writing in order to let other researchers evaluate how my conclusions are transferable to other learners in different contexts.

To establish dependability and confirmability, I enlisted the help of a cocoder (see description of co-coding process above), I kept an audit trail (I have separate files of my raw data, each separate attempt at descriptive coding, and each version of axial coding; I also have series of process notes starting from my initial development of a guiding question, through the design, data collection, data analysis, and write-up of the study) and I have attended to reflexivity at every step of the research process (in fact, after conducting the initial phases of analysis [descriptive and axial coding] from February-April, 2014, I chose to significantly slow down my data analysis process, and for several months thereafter I simply considered my data, continued to read and reflect on similar studies in applied linguistics as well as postmodern feminist theory, and re-analyzed portions of the data, keeping in mind the strong and weak points of my analysis as time passed).

Ethical issues. Although steps were taken to ensure that this research was conducted ethically, there are three potential ethical issues that could have 
developed in this study: obtaining true informed consent from the participant and avoiding coercion to participate in the study, ensuring that the participant did not feel coerced to share information that would make her feel awkward, uncomfortable, frustrated, or embarrassed, and maintaining the participant's confidentiality.

As I described above, in order to obtain true informed consent, I went through an oral informed consent process with the participant. In addition, although there was a risk that Rosa would feel awkward, uncomfortable, frustrated, or embarrassed, I believe that her stating multiple times that she enjoyed our conversations, she wanted to be able to share her story, and she felt comfortable around me shows that this risk was mitigated. The last ethical issue that could have arisen regards maintaining the confidentiality of the participant.

While I maintained confidentiality by only using the participant's pseudonym, giving the institution I was working at a pseudonym, and otherwise avoiding references that would make the location of my research fairly obvious, there is always a chance that a reader of this thesis might be able to identify Rosa. As a volunteer tutor at this institution, I frequently discussed the progress of my students (including Rosa) with my supervisor, so it would be possible that if my former supervisor were to read my thesis, she would be able to discern who Rosa is. In addition, even though Rosa's teacher never appeared to be aware of who my participant was, if she were to read my thesis, she would most likely instantly know who the student was because she knows the life stories of many of her students. Although Rosa's teacher and my supervisor's knowledge of who my participant is 
could be a potential ethical issue, I believe the consequences of this knowledge are fairly minimal and can be mitigated in the following ways: Rosa is no longer in this teacher's class nor is she currently at Stumptown School, her access to education will not be affected by her (former) teacher's potential knowledge of her participation in my study, and I have not disclosed any information about Rosa that would compromise her in any way should anyone outside of Stumptown for any reason be able to figure out who she is.

Benefits to the participant. Despite the potential ethical issues discussed above, I believe that the benefits to the participant outweighed the potential costs. Because Rosa gave me her time (1-1.5 hours every other week) I would like to give Rosa some of my time by offering to tutor her again once my thesis is complete and I no longer fall under PSU's IRB's injunction to not blur the line between researcher and teacher. Along with the possibility of receiving more tutoring, Rosa also had the benefit of being able to share her story with an interested and engaged listener.

\section{Limitations}

There are a number of limitations in my study. First, the time frame of this study is fairly limited in comparison with other longitudinal qualitative studies. Although I had prolonged contact with Rosa before beginning the study, a study over the course of one academic term (with one later follow-up interview) may not have been enough time to gather the kind of rich, deep data I am interested in. Second, because I have only one participant in a limited context, I face the same limitation in transferability as other researchers using case studies. However, because my goal is to discuss what students report, I believe that one case study is 
the best framework for answering the guiding question I have posed, and I hope to provide enough rich, thick description that others may be able to transfer the findings to other contexts when appropriate. Third, because I was the sole researcher in this project, there is always a possibility that I may be subject to my own "analytical biases" (Perry, 2011, p. 161). I attempted to counteract this possibility by discussing my findings with a co-coder, with peers and with my advisor in order to get outside perspectives on my work.

\section{Conclusion}

In this chapter, I have elucidated the site and research participant, my background and role in the study, my data collection and analysis procedures, and ethical issues, benefits to the participant, and limitations to my study. In the next chapter, I will present the results of my data analysis as well as discuss my interpretations of these results. 


\section{Chapter 4: Findings and Discussion}

This study was designed to explore one English language learner's identity and investment in a community ESL classroom. Specifically, this study was guided by this question:

When describing her investment in a community ESL program, how does one adult English language learner characterize the relationship among her identity, the social context of her life, and her classroom space?

In this chapter I present the data and my analysis; believing that description and interpretation of the data are mutually supportive of each other, I will interweave reports on my findings and a discussion of these results. Wolcott, in explaining how to strike a balance between description and interpretation when reporting on qualitative data, paraphrases anthropologist Jules Henry: "humans are not only capable of learning, and, by extension, of thinking, about more than one thing at a time, they are incapable of learning, and thus of thinking, about one thing at a time," (1994, p. 47).

In addition, in my presentation of the data, I have chosen to reproduce very large blocks of quotes from Rosa for the reason that "in the human sciences firstperson accounts in the form of personal narratives provide a much richer source of data than do third-person distal observations" (Pavlenko \& Lantolf, 2000, p. 157). In addition, I believe that "research on L2 narratives...should not be restricted to the written accounts of people of letters....An interesting and important question is to what extent and by what means do the countless others who have attempted to 
cross borders, but who have not, or cannot write about it, achieve transgredience [the ability to perceive interactional events from outside of the event itself and in which attention is focused on the resources and identities involved in the event]?" (Pavlenko \& Lantolf, 2000, pp. 174-175). As Rosa's quotes show, she speaks of her experiences learning English and interacting with others in the US in a way that is "as legitimate and revealing" (Pavlenko \& Lantolf., 2000, p. 175) as my interpretations of her words.

I begin this chapter by outlining my argument as a whole, which arose from the axial coding and which led to Figure 2 (see Chapter 3). Next, I construct my argument by exploring the themes surrounding the two focal codes of my study: the factors affecting Rosa's participation in class and the factors affecting Rosa's investment into learning English. Finally, I present a discussion relating to her identity and agency.

The major findings from this thesis indicate that Rosa has a great deal of investment in learning English and, yet, showed a surprising lack of participation in her ESL class. I contend that non-participation should not be equated with noninvestment, as has been done by previous researchers (e.g., Norton, 2001, Miller, 2009). Analyzing the data collected in this study shows that Rosa's nonparticipation was mainly due to her lack of education, the decontextualized and abstract English taught in class, the bureaucratic systems of Stumptown School, her relationship with her teacher, her physical barriers, her work schedule, and her family commitments. The biggest factors in her deep investment in learning English was her desire for self-advocacy. These factors are linked to her identity positions 
as "burra / stupid" and "no preparada / uneducated": Rosa's self-labels of "burra" and "no preparada" caused her to desire to learn English, and yet she felt out-ofplace and uncomfortable in the formal language-learning environment.

These self-described inferior identity positions contrasted starkly with Rosa's agency. If individuals can have greater or lesser amounts of agency, Rosa's agency is immense. Her willpower to succeed is only matched by the system's power to oppress her, and Rosa has, for the most part, been able to succeed in her endeavor to learn English. Throughout our interviews, Rosa's relationship with learning English clearly indexed the extraordinary amount of agency that she had in participating in her particular ESL classroom and in investing in learning English in general.

This thesis explores the two focal points (participation and investment), linked through Rosa's identity and investment, which emerged after I completed an analysis of my data via axial coding (see Figure 2 in Chapter 3). It is beyond the scope of this thesis to discuss each of the factors in detail, so below, I will only discuss the most salient factors for each focal point. The factors that I have chosen not to directly discuss in this thesis are mentioned in connection with factors below (e.g., Rosa's desire to pronounce English well [coded as lo puede uno pronunciar bien / PRONUNCIATION] stemmed from her desire to be accepted by American Englishspeaking communities [coded as estás en la calle con unas personas burlescas / INTERACTING WITH STRANGERS IN THE US (OUT OF CLASS)]; I chose to focus on her interactions with Americans instead of focusing on pronunciation). 


\section{Factors Affecting Rosa's Participation in Class}

The first focal point of my study was Rosa's agentive self in her participation (or non-participation) in one particular learning environment: the community ESL classroom. Rosa chose to attend class almost every day for two primary reasons: she felt that the best way to learn English was in a formal classroom with a teacher, and she enjoyed learning with and from her fellow classmates. However, her ability to participate in class was circumscribed by a number of factors related to the school itself and related to the social context of her life.

My conclusion that Rosa's actions in class generally constituted "nonparticipation" was based on my obserations of her in-class behavior and her statement of "I just sit there" to describe what she generally did. Examples of her inclass behavior included never voluntarily supplying an answer when the teacher asked for whole-class responses, only participating in whole-class activities when prompted by the teacher, and never asking the teacher a question unless she was engaged in an activity with a partner and the teacher checked in to see the pair's progress. In addition, Rosa reported that she rarely completed her homework (with homework completion generally being considered "participation" by teachers). My observations of Rosa in her Intermediate-Low class and Rosa's reports contrasted strongly with my observed behavior of her when she was in my literacy-focused class the previous year (she had been gregarious and eager to supply answers, assist classmates, ask clarification questions, and engage both me and her classmates in discussions on life and learning); therefore, I believe that while she wasn't exactly doing nothing in her Intermediate-Low class, her actions were very close to "non- 
participation."

There were 11 different descriptive codes from my interview data that directly influenced what Rosa did in class (labeled as the focal code me voy, me siento, y allí estoy / I JUST SIT THERE = WHAT I DO IN CLASS (AGENTIVE); see Chapter 3 for the complete descriptive coding table.)

School space. Four of the codes, unsurprisingly, were related to the school space: 1) habemos muchos estudiantes / OTHER STUDENTS IN THE CLASS; SOCIAL INTERACTIONS IN THE CLASS, 2) esa escuela / THE INSTITUTION, 3) ustedes / esa maestra / TEACHERS IN GENERAL, and 4) todo que ella dictó escribimos / WHAT HAPPENS IN CLASS. The two most influential reasons for Rosa's attendance in the class were her belief in the efficacy of classroom learning and her desire to spend time near her fellow classmates; this was balanced by the institutional barriers at Stumptown School, her rocky relationship with her teacher and by the abstract, decontextualized English that was being taught in the class.

Social interactions in the class. Rosa's interactions with the other students in her class were generally a positive influence on her in-class actions. During our third interview, Rosa described the other students' presence as one of her favorite parts of being in class. She was extremely heartened when a majority of the students showed progress in the class, and she was always sad when students missed class or eventually dropped out. Rosa described a strong sense of community and of solidarity with her classmates. On several occasions, she described helping and encouraging her fellow students, sometimes during in-class activities, and sometimes outside of class. 
One passage that particularly illustrates the sense of camaraderie that Rosa reported having with her classmates and the influence that her classmates had on Rosa's desire to come to class is the following:

(4.a) Excerpt from Interview \#3:

1 R- Mucha gente me dice a mí, "Yo no sé pa que vas a la escuela, si ya estás 2 grande, ya no necesitas [...]" "Yo voy a la escuela porque yo, yo quiero," le 3 digo, "entender un poquito del inglés, es todo." [20 seconds later in the 4 interview] Bueno, pero me gusta, ¿cómo te diré? relacionarme con los, con 5 diferentes personas, de los diferentes países que van a la escuela. Creo que 6 llegan rusos, llegan cambodianos, llegan japoneses, llegan, como... Guatemala, 7 Honduras, todos llegan allí, es bien, digo yo, ¡de dónde venimos de diferentes

8 lugares y [...] ganas del inglés! Unos no dicen nada, unos que ya entienden, 9 otros que escriben mucho pero no saben hablar nada [laughs]. Digo yo, 10 ¡Wow!

11 J- ¡Sí! Yo, cuando yo estoy en clases así, es como, hay veinte almas diferentes, 12 ¿no?

13 R-Sí

14 J- que han ba- ¿que han transladado? no. Que se han mudado por todo el 15 mundo.

16 R- Sí.

17 J- Y por alguna razón han llegado al mismo aula

18 R- ¡Mmhmm!

19 J- A la misma hora

20 R- Sí

21 J- Para hacer la misma cosa

22 R- Sí

23 J-Y es... es mágico, ¿no?

24 R- Sí, porque imagínate de dónde cada quien es, desde dónde vienen, y como

25 dices, al llegar allí y encerrarse para poner atención a la persona que nos está 26 enseñando, y dices, ¡Wow! Está... [...] [laughs]

27 J- Mmhmm, mmhmm.

28 R- Pero sí, sí es bueno. Es bueno conocer, conocer cada persona, cómo son.

29 Cómo se portan, cómo hablan, cómo tratan de aprender qué es su, su ¿cómo

30 se dice? Su sueño americano, porque cada uno de ellos traemos un sueño. Yo

31 ya no, porque ya no, pero, la mayoría de los que llegan a estudiar, pues, son

32 los quieren ser, que abogados, otros que quieren ser enfermeras, que otro

33 que doctor, que otro que soldador, que otros que mecánico, que otros... tiene 34 cada quien su... y, y muchos sí lo llegan, muchos pues no lo llegan, porque se

35 le hace difícil el inglés [laughs], y para estudiar a ese grado, yo pienso que 36 tienes que tener buena preparación desde el país de dónde uno viene, porque 37 si no, para empezar de aquí desde abajo, es muy difícil. 
J- Mmhmm.

R- Sí. Sí, como el señor que estaba junto de mí, él dice que está aprendiendo para ser soldador, dice. "Pues," le digo, "pues yo no aprendí, pero yo sé hacerlo," [laughs] le dije. "Yo no, osea, yo no ¿cómo se dice? yo no estudié, pero yo sé soldar,” le dije. “¿Pues sí sabes soldar?” Le digo, “Sí. Yo trabajé en una compañía [...] soldadora. Yo sé soldar los refrigeradores, las sillas, las dumpsters de basura, los troques, los tubos, pues, sí sé soldar. " J- ¡Wow!

\section{(4.a) GLOSSED Excerpt from Interview \#3:}

R- Many people say to me, "I don't know why you go to school, if you're already grown up, you don't need [...] any more" "I go to school because I, I want," I say, "to understand a little bit of English, that's it." [20 seconds later in the interview] Well, but I like, how can I tell you? To connect with different people from different countries that go to school. I think that Russians come, Cambodians come, Japanese come, like... Guatemala, Honduras, everyone comes here, it's good, I say, we all come from different places and [...] desire of English! Some don't say anything, some already understand, others who write a lot but don't know how to say anything [laughs]. I say, wow! J- Yeah! I, when I was in classes like that, it's like, there are twenty different souls, right?

R- Yeah

J- who have co-who have moved [uses wrong word]? no. Who have moved from all over the world.

R- Yes.

J-And for some reason they've arrived in the same classroom

R- Mmhmm!

$\mathrm{J}$ - At the same time

R- Yes

$\mathrm{J}$ - To do the same thing

R-Yes

J- And it's... it's magical, right?

$\mathrm{R}$ - Yes, because imagine where everyone is from, from where they came, and like you say, upon arriving there and shutting yourself [in the class] to pay attention to the person who is teaching us, and you say, wow! It's... [...] [laughs] J- Mmhmm, mmhmm.

R- But yes, yes it's good. It's good to know, to know each person, how they are. How they act, how they speak, how they try to learn what their, their, how do you say? their American dream is, because each one of us carries a dream. I don't any more because not any more, but the majority of those who come to study, well, there are those who want to be lawyers, others who want to be nurses, another a doctor, others mechanics, others...each one has their... and, and a lot of people do make it, well a lot don't make it, because 
35 English is difficult for them [laughs], and to study at that level, I think you

36 need to be well educated from the country that you come from, because if

37 not, to start here from the very bottom, it's very difficult.

38 J-Mmhmm.

39 R- Yes. Yes, like the man who sits next to me, he says that he's learning to be

40 a welder, he says. "Well," I tell him, "well I never learned, but I do know how

41 to do it," [laughs] I told him. "I don't, like, I don't, how do you say? I didn't

42 study, but I know how to weld," I told him. "So you know how to weld?" I

43 told him, "Yes. I worked in a company [...] welder. I know how to weld

44 refrigerators, chairs, dumpsters for trash, trucks, tubes, so, yes I know how to

45 weld."

46 J- ¡Wow!

Excerpt (4.a) shows a number of things: Rosa's enjoyment of going to school

is tied to getting to know her classmates, people from all over the world (lines 1-27)

who are (sometimes) able to achieve their dreams (lines 28-34). Rosa is able to

learn from watching how the other students learn (lines 28-29), and she is able to

share her expertise with her fellow classmates (lines 39-46) in a way that is not

often validated by other people she has encountered in the United States (see

section "Social context of her life" below). In addition, she connects other students'

former educational experience with their ability to succeed in the English class and

points out how difficult it is for learners without formal educational backgrounds

(such as herself) to succeed (lines 34-37).

Institution. The institution of Stumptown School was, in general, not a

positive influence Rosa's exercise of in-class agency. The topic of the institution

came up 18 times, and of those, several indicators referred to Rosa's inability to

navigate the bureaucracy of the institution. Most notably, Rosa has poor eyesight

due to a very bad car accident she was involved in several years ago, and so she has

trouble seeing things that are projected onto a screen or onto the white board. She 
attempted to go through Stumptown's disability services in order to get special accommodations in the classroom, but she was never able to complete each of the steps to the institution's satisfaction in order to be allowed accommodations. In our first interview, she made the following comment:

\section{(4.b) Excerpt from Interview \#1:}

1 ...tienes que ir a disability, y quien sabe que, se necesita disability, no no

2 estaba, fui, dejé los papeles, no me los-no los pusieron en la computadora,

3 so yo me no [...]. Dije, yo ya no voy a ir, mejor voy a seguir como soy.

\section{(4.b) GLOSSED Excerpt from Interview \#1:}

1 ...you have to go to disability, and I don't know what, you need [the] disability

2 [office], nobody was there, I went, I left my papers, they didn't-they didn't

3 put them in the computer, so I didn't [...]. I said, I'm not going to go [back to

4 that office] anymore; it's better that I continue as I am.

Her frustration with the disability services' office led her to stop pursuing accommodations, which meant that she wasn't able to clearly see anything that the teacher projected onto the board during the regular class time using the overhead projector. In addition, the class spent one hour each week going to the computer lab. In previous classes, her previous teacher had provided a darkening screen for Rosa so that the brightness from the computer screen wouldn't hurt her eyes, but Rosa was unable to get such a screen for her current class due to her lack of disability accommodations from Stumptown, which impacted her ability to fully participate during the computer lab sessions. During our interviews, Rosa reported many times that she felt like her head would "explotar / explode" when she was looking at the computer, and during the first class I observed Rosa in, I sat behind her and watched as she leaned in to the screen to read the text and then lean away 
again as she struggled to focus.

In addition, many indicators in this code referred to the institution's rule that students could only take the same class at the same level three times; if students don't pass the class after the third try, they are kicked out of the institution. Rosa was in the Intermediate-Low class for the third time when I was observing her, so we discussed the possibility that she might not be able to take further classes at Stumptown. However, it is important to note my bias as a researcher and as her former teacher here: I was incredibly concerned that Rosa might not have further access to classes at Stumptown, so I brought up this institutional rule several times during our interviews, asking how Rosa felt about it and what her future plans were.

Rosa did not seem to express the same level of concern as I felt about her future access to language learning; during our first interview, she made the comment:

(4.c) Excerpt from Interview \#1:

1 Y digo yo... pero si no... ya no me quieren a ir, voy a buscar otro lado. No me 2 voy a dejar. [laughs].

(4.c) GLOSSED Excerpt from Interview \#1:

1 And I say...but if they don't...if they don't want me to come any more, I'm

2 going to look for another place. I'm not going to let them do that to me 3 [laughs].

This comment indexes how the institution and its policy of not allowing students to repeat classes indefinitely ("if they don't want me to come any more...") might be directly responsible for Rosa's participation in this program's ESL classes, but the institution itself has nothing to do with her overall desire to learn English 
("I'm going to look for another place. I'm not going to leave myself behind.").

Teachers in general. In general, Rosa felt that she needed a teacher in order to learn English. She de-valued the English that she learned "nomás así en la calle / just in the streets like that" (Interview \#1) and instead spoke happily about the idea of having a teacher. However, Rosa did not have a particularly good relationship with the teacher in the Intermediate-Low class that I observed. She felt that her teacher moved too quickly through the material and that her teacher didn't give enough support for students like Rosa who were struggling in class (see lines 1-11 and 31-35 in (4.d) below). One particular frustration that she expressed was that her teacher would not help her with the physical accommodations she needed. Rosa and I discussed her experience in general with education, and Rosa compared her current teacher with a teacher she'd had in previous terms (see lines 29-30 and 42-

54 in (4.d) below; I gave Rosa's previous teacher the pseudonym of "Pam"):

(4.d) Excerpt from Interview \#1:

$1 \mathrm{~J}-\mathrm{Y}, \mathrm{um}$, con todos los maestros en [NAME OF INSTITUTION], con la maestra 2 que tiene ahora, con los otros, ¿han dicho algo de dar más apoyo o siempre 3 han estado...?

4 R- La... No, no, no. La única, la única, la única [with emphasis] maestra de 5 todas me ha, la que más me ha ayudado era la maestra Pam. No voy a decir 6 otra cosa, más que, esta maestra con la que estoy ahorita, en los primeros 7 días, sí me trató mal. "Oh, tienes que [...] Yo no tengo el tiempo lo suficiente 8 para estar poniéndote atención a ti, y blah blah blah blah." Y ok, dije yo, ya 9 por eso ahorita ya casi mejor no hablo. Mejor no más estoy escuchando, 10 escuchando, escuchando, y por lo rest, no [...] preguntas, pues sí. Pero, como 11 antes, que [clears throat] le decía yo, "necesito las letras más grandes porque 12 tengo la carta del doctor." Y me dice, "Oh, para eso tienes que ir a disability, 13 quien sabe que," y se necesita disability, no no estaba, fui, dejé los papeles, no 14 me los-no los pusieron en la computadora, so yo me no [...]. Dije, yo ya no 15 voy a ir, mejor voy a seguir como soy. Porque realmente si ellos quisieran 16 ayudarle a uno, fuera diferente. La maestra Pam sí me ayudaba mucho. Y me 17 dicho, haz esto, haz esto, haz esto. [...10 minutes later in our interview...] y 
digo, "Oh my God, ¡yo no quiero estar con esta maestra! ¡Yo quiero [...] con la maestra Pam!" Pero, digo, "No, es imposible." Digo, la maestra Pam es muy buena maestra.

$$
\text { J- Sí }
$$

R- Es muy buena maestra. Ella entiende, y se presta platicar con ella, y aunque yo sé que anda a las carreras pacá y pallá, pero le pone a uno mucha atención. Es muy buena maestra. Y ya tiene tiempo que no la he visto. J- Pero cuando yo estaba en [NAME OF INSTITUTION], Pam me ayudaba mucho, porque yo decía, "No sé qué hacer, no sé dónde hay materiales, no sé quién es quién," y ella me ayudó tanto a ser una buena maestra. Y me imagino que es lo mismo con usted.

R- Oh, sí, ella es una muy buena maestra, la verdad. De todas maestras que he visto yo allí, es ella, y esta... otra, una muchacha que estaba pero dicen que se accidentó, ya no la he visto yo a esta muchacha. Y tú. J- Mmm. Gracias.

R- Sí, porque, la verdad, cuando nos estabas enseñando, está muy bien para mí, que yo no, no sé, estaba muy bien, a mí me gustaba todo como, como iba aprendiendo.

\section{(4.d) GLOSSED Excerpt from Interview \#1:}

J- And, um, with all of the teachers in Stumptown School, with the teacher that you have now, with the others, have they said anything about giving you more support or have they always been...?

R- The... No, no, no. The only, the only, the only [with emphasis] teacher of all [who] has has, the one who has helped me the most was the teacher Pam. I'm not going to say anything more, except, that teacher that I'm with now, in the first days of class, she did treat me badly. "Oh, you have to [...] I don't have enough time to be paying attention to you, and blah blah blah blah." And OK, I said, because of that for now perhaps I almost don't speak. I'd better just listen, listen, listen, and for the rest, no [...] questions, so yeah. But, like before, that [clears throat] I told her, "I need the letters [on the screen] to be bigger because I have a doctor's letter." And she tells me, "Oh, for that you have to go to disability, and I don't know what," you need [the] disability [office], nobody was there, I went, I left my papers, they didn't-they didn't put them in the computer, so I didn't [...]. I said, I'm not going to go [back to that office] any more; it's better that I continue as I am. Because if they really wanted to help you, it would be different. The teacher Pam did help me a lot. And she told me, do this, do this, do this. [...10 minutes later in our interview...] and I say, "Oh my God, I don't want to be with this teacher! I want [...] with the teacher Pam!" But, I say, "No, it's impossible." I say, the teacher Pam is a really good teacher.

J- Yes 
25 but she pays a lot of attention to you. She's a really good teacher. And it's

26 been a while now that I've seen her.

27 J- But when I was in Stumptown School, Pam helped me a lot, because I

28 would say, "I don't know what to do, I don't know where there are materials,

29 I don't know who is who," and she helped me so much to be a good teacher.

30 And I imagine it's the same with you.

31 R- Oh, yes, she really is a good teacher, truthfully. Of all the teachers that I've

32 seen there, it's her, and that... other, another girl that was there but they say

33 she got into an accident, and I haven't seen that girl any more. And you.

34 J- Mmm. Thanks.

35 R- Yes, because, truthfully, when you were teaching us, it was really good for

36 me, that I didn't, I don't know, it was really good, I liked how everything, how

37 I kept learning.

This excerpt speaks volumes to how Rosa seems to equate her learning with

who the teacher is. Rosa's positive relationships with previous teachers led to her

feeling like she was valued by her teachers (lines 47-48) and which also helped her

feel like she was able to learn during her classes (lines 58-59). In contrast, her

negative relationship with her current teacher led her to feel like she had to stop

participating in the class altogether (lines 32-33: "for now perhaps I'd better almost

not speak. I'd better just listen, listen, listen, and for the rest, no [...] questions, so

yeah.").

In addition, excerpt (4.d) shows how, even though Rosa was very frustrated

with the bureaucracy of the disability services office, she seemed to blame her

current teacher for not helping her more with the process rather than blame the

system itself, contrasting that teacher's actions with those of Pam: "The teacher Pam

did help me a lot. And she told me, do this, do this, do this" (lines 41-42; during my

informal conversations with Pam when I had been a volunteer teacher at

Stumptown, Pam had indeed tried to walk Rosa through the process of getting

formal accommodations; the reasons why Rosa had been unsuccessful at that time is 
not within the purview of this study, but Rosa's acknowledgements that Pam had been helpful show a distinctive contrast with Rosa's perceptions of her current teacher's actions.)

It is important to note that, as I observed Rosa over the course of the term, her amount of in-class participation especially during small-group and pair work did increase; at the same time, she reported feeling more cordial towards her teacher. During our third interview, which took place one day after her last day of class and eight weeks after our first interview, Rosa commented that her current teacher had changed a lot. Whereas in previous classes, Rosa had perceived the teacher's attitude as "racista...rara...creída / racist...weird...stuck-up," she said that during the current term that I observed her, the teacher appeared to be changed, and "más entrada en su trabajo / more engaged in her work" (Interview \#3). I would not find it surprising if Rosa's in-class participation increased because she felt more comfortable in the classroom, which may have been due to feeling more comfortable with the teacher.

Rosa did pass her Intermediate-Low class during the term that I observed, and she moved up to the Intermediate-Mid class during Winter of 2014. The Intermediate-Mid classes at Stumptown have much higher academic expectations for students, one consequence of the higher academic expectations was that students were given a syllabus (I am not entirely certain if Rosa had ever gotten a syllabus in her previous classes, but she described the class syllabus in terms that made me assume it was a new concept for her). Rosa partly blamed the educational system for giving teachers a prescribed curriculum that they have to teach from 
(lines 1-15 in (4.i) below), but she also equated her Intermediate-Mid teacher's adherence to the syllabus with that teacher's other "strict" (line 53) actions in class, which caused Rosa drop the class entirely (see lines 15-57).

What happens in class. The general routines of the class was a topic that I brought up several times because I was interested in hearing how Rosa's framing of what happened in the class was different from what I observed.

One issue that she mentioned several times was the pressure of having to move quickly through material in order to be tested, and the additional pressure that the class's periodic tests brought. Rosa's frustration with the amount of time spent on tests (she thought there was too little time given to students on each individual test, but she also thought there should be fewer tests, and more time spent on learning how to "explicar el inglés, entender el inglés / explain English, understand English" (Interview \#2) and not so much on learning and testing abstract grammar points) was palpable. She often worried about what would be on the tests and when the tests were going to be. While test anxiety seems to be a regular feature of academic life in the US, the Intermediate-Low class at Stumptown is still supposed to be community ESL, where more alternative forms of assessment would be able to more accurately capture students' knowledge of English, instead of students' knowledge of how to fill out a test.

During our third interview, when I asked her what she'd learned over the course of the term, she specifically mentioned learning the pronunciation three allomorphs of the -ed simple past ending (practicing and identifying these allomorphs was something that the teacher had spent a great deal of time on in 
class, which I assume was to prepare students to succeed at higher levels of classes, as using the IPA as a pronunciation strategy is a required course outcome for advanced classes at Stumptown School). However, in the same breath, Rosa admitted to still not quite grasping the idea and having done poorly on the test (Interview \#3).

The -ed endings was something that Rosa framed as belonging to some feature of a category we might call "classroom English" or "words that go on the test," not as the category she would label "explaining English, understanding English." The classroom English that I observed being taught was often divorced from the wider context of "understanding English." Rosa referred to this gap between classroom English and outside English in our fourth interview, when she discussed all of the things that she needed to be able to say but hadn't learned in the classroom:

(4.e) Excerpt from Interview \#4:

1 R- Y, para el paso del inglés que, que yo he tomado, pues sí nos han dado un 2 poquito de una cosa, un poquito de otra, pero sin embargo, ¡mucho más 3 todavía! [...] necesita. Y para eso, pienso que es muy difícil. Es muy difícil, 4 como, tomar las clases para la profesora y para el estudiante, porque, es 5 bastantes cosas. Imagínate que como, de repente, hay que decir, "piedra," o 6 de repente hay que decir, "una bala," o de repente hay que decir que, "Fulano 7 mató a fulano," Esas son cosas muy delicadas. 0 que de repente hay que 8 decir que encuentres un muerto allá, y esas son cosas que son espantosas. 9 Entonces, ¿cómo puedes defenderte tú, ya por la ley, si llegas ver un caso de 10 criminales? Allí son cosas muy delicadas, que dices, wow, mejor muchos de 11 nosotros latinos, mejor no abrimos la boca, porque tenemos miedo que ese 12 caso, que en vez de que, que uno... ayuda a la persona, al contrario a nosotros 13 nos meten a la cárcel. Entonces, si ves algo, mejor no digas nada. (4.e) GLOSSED Excerpt from Interview \#4:

1 R- And, for the path of English that, that I've taken, well they have given us a 
2 little bit of one thing, a little bit of another, however, [there is] still so much 3 more! [...] need. And for that, I think it's really difficult. It's difficult, like, to 4 take the classes for the teacher and for the student, because, it's a lot of 5 things. Imagine that like, all of a sudden, you have to say "rock," or suddenly 6 you have to say, "a bullet," or suddenly you have to say, "So-and-so killed so7 and-so," These are really delicate things. Or suddenly you have to say that 8 you've found a dead person there, and these are horrible things. So, how are 9 you going to stand up for yourself in front of the law, if you end up seeing a 10 criminal case? These are really delicate things, that you say, wow, a lot of us 11 Latinos had better not open our mouths, because we're afraid that in that 12 case, that instead of, of you... helping the person, on the contrary they put us 13 in jail. So, if you see anything, you'd better not say anything.

One of Rosa's main influences to learn English was to stand up for herself with the law (see section Police/Legal Issues below), and yet, the kinds of English being taught in the classroom wasn't the kinds of things she needed ("piedra / rock," "bala / bullet," "fulano mató a fulano / so-and-so killed so-and-so").

In conclusion, what Rosa described as happening in her English class was a lot of pressure to learn things quickly; a lot of stress to take multiple tests, each in a short amount of time; an emphasis on decontextualized, abstract language; and a lack of real-world applicability of much of the language that was focused on. Each of these aspects of what was happening in class negatively influenced what Rosa did in class: she often couldn't follow along with the fast pace; she couldn't adequately show her knowledge on the tests (and instead just "answered whatever"); she gave a genuine effort to learning the grammar points ("and I know that the gramgrammar is really good") but often did not succeed in performing the grammar; and she wasn't able to spend class time on learning what she needed to learn to survive in her outside life. 
Summary of school space. To summarize this section, four main aspects of the school space affected Rosa's participation in class. First, the institution itself was generally a barrier for Rosa, especially in her inability to get the disability accommodations she needed and in its potential threat to disallow Rosa to continue with classes at the school; however, Rosa did not characterize the institution as having absolute control of her learning, and she declared that she would keep learning no matter if the school kicked her out or not. Second, Rosa's relationship with her Intermediate-Low teacher was rocky and with her Intermediate-Mid teacher was even worse, which negatively impacted her in-class participation. In addition, Rosa viewed her teachers as being a necessary part of English language learning, and heavily depended on their emotional and pedagogical support. Third, Rosa's interactions with her classmates were a very positive pull for her to attend and participate in class; she often went to class because she was lacking social interactions in the other parts of her life, such as with her family or at work. Fourth, the general routines and activities of the classroom were not particularly conducive to her active participation in class, because there was a lot of stress to go through material quickly and to take multiple tests to prove mastery of material, there was an emphasis on abstract grammar points, and the language being taught did not necessarily align with Rosa's language needs.

Next, I will analyze the codes from the social context of Rosa's life that affected her participation in the classroom.

Social context of her life. Another set of codes that directly influenced what Rosa did in class were related to the social context of her life. Specifically, the 
following 3 codes had causal relationships with me voy, me siento, y allí estoy / I JUST SIT THERE = WHAT I DO IN CLASS (AGENTIVE): 1) yo fui madre y padre para mis hijos / FAMILY, 2) trabajando / WORK, and 3) personas ya preparadas / yo soy la persona más...burra / LACK OF PRIOR EDUCATION. (Another code, Yo estoy mal de mi vista / tuve un accidente / PHYSICAL BARRIERS AND DIFFICULTIES was an additional factor that directly affected what Rosa did in class, but as her vision impairment has already been discussed in above sections, I will not elaborate further on it here.)

Family. Rosa recounted many details of her family life and living situation to me during our interviews, but she prefaced some of these statements with, "Como amigas, te confío... / As friends, I'm confiding in you..." I have chosen to only recount the details that are necessary for this thesis and to avoid other personal details that Rosa might find painful.

Rosa has not had a simple family life. She did not go to school in Mexico, and instead worked in her family's fields from the age of 4 or 5 . Rosa emigrated from Mexico with her three children at the age of 18. She was the children's primary caretaker in the US for most of her years with them, so she had to work several jobs instead of going to school. Over the years, all three of her children moved back to Mexico, including her mentally disabled daughter, whom the family lost track of for several years and only found again at the beginning of 2014 , during the time I was interviewing Rosa.

Many years after arriving in the US, she married a man who later emptied her bank account and left her homeless. During the decade that she was married, her 
husband wouldn't allow her to go to English classes; however, when they separated, Rosa began going to school precisely because she didn't live with her husband any more and she needed social interactions in English.

After her husband left and Rosa lost her house, she moved in with her son, his wife, their two very young children, and her daughter-in-law's parents. Her daughter-in-law and her daughter-in-law's parents are Americans who speak English as a first language, so Rosa has the occasional opportunity to interact with them, but each of them has a job and their schedules don't overlap with hers, therefore they had very little communication. Therefore, in order to have people around her to ask questions about English, Rosa had to seek out English classes.

At the time of our final interview, Rosa's daughter-in-law was planning to move to Mexico to be with her husband (Rosa's son), and she was planning to take her son (Rosa's grandson) with her. During the time of our interviews, Rosa was the primary caregiver for her grandson, because her daughter-in-law had an intensive work schedule. During our fourth interview, Rosa discussed her even greater desire and ability to attend class after she would be much more alone at home (see lines 30-31 in excerpt (4.f) below). Rosa began by discussing how she regretted not going to school when she first arrived in the United States:

(4.f) Excerpt from Interview \#4:

1 R- Yo, cuando llegué aquí, llegué a los 18 años. Tenía yo 18 años. En ese 2 tiempo: ¡inglés, gratis! ¡libretas, gratis! ¡lápiz, gratis! Todo te daban gratis. 3 Casi ya hasta te querían pagar pa que fueras a la escuela. Y no lo hacíamos. 4 [2 minutes later in the interview] Yo sí me repiento, pero en otra manera no 5 me repiento porque tengo mis hijos que ya están grandes y mis hijos me 6 necesitaban más en ese tiempo también. Entonces por eso ahora digo yo, 7 también que yo aprendo un poco de inglés porque ya no tengo con quien 
compartir mis ratos. En ese tiempo, pues, llegaba yo del trabajo. "Mamá, ¡quiero comer!” Oh, “Mamá, quiero esto." Oh, “Mamá, esto, mamá, esto..." No tenía yo tiempo para nada. Entonces digo, ahora sí, ahora sí tengo tiempo. Nomás tengo a mi nieto pero a veces lo llevo a una casa de una señora que me lo cuide-yo le pago. Ya. Me voy. A mi escuela. Pero cuando tengo cosas que no, no son muy, ¿cómo se dice? muy, muy, así... restringidas para el niño, sí lo llevo. Sí. Yeah. Es [...] para mí. Pero sí, sí... sí, me gusta. Me gusta mucho el inglés, aunque me agarra mucho la cabeza y siento que ya salgo de cabeza, pero sí me gusta. Sí me gusta. Sí me gusta. Me gusta mucho. Mucho, mucho, mucho, me gusta. Me gusta mucho Estados Unidos también [laughs]. J- [laughs] Bueno, está bien que está aquí pues.

R- Sí, me gusta mucho Estados Unidos. Sí, por eso estoy acá, y por eso elegí a Estados Unidos. Si no, me hubiera ido a otro país. J- Mmm. R- Sí. Imagínate, tuve tres niños. Dieciocho años. Yo me vine de Estados Unidos. Yo sola. J- Wow. Qué difícil. R- Muy, muy, muy difícil. Pero nada imposible. Cuando uno quiere y tiene el sueño, sí lo realiza.

\section{(4.f) GLOSSED Excerpt from Interview \#4:}

R- I, when I arrived here, I arrived at 18 years old. I was 18 years old. In that time: English, for free! Notebooks, for free! Pencil, for free! They gave you everything free. And we didn't do it. [2 minutes later in the interview] I do regret [it], but on the other hand I don't regret [it] because I have my children who are now grown up and my kids needed me more in those times also. So for that reason now I say, I should also learn a little English because now I don't have anyone to share my time with. In those times, well, I would come home from work. "Mamá, I want to eat!" Oh, "Mamá, I want this." Oh, "Mamá, this, mamá, that..." I didn't have time for anything. So I say, now yes, I do have time now. I only have my grandson but sometimes I take him to the house of a woman who takes care of him for me-I pay her. That's it. I go. To school. But when I have things that aren't, aren't very, how do you say? Very, very, like... restricted for the boy, I do take him along. Yes. Yeah. It's [...] for me. But yes, yes... yes, I like it. I like English a lot, even though my head grips me and I think I'm going to leave my head, but I do like it. Yes, I like it. Yes, I like it. I like it a lot. A lot, a lot, a lot, I like it. I like the United States a lot too [laughs].

J- [laughs] Well, it's good that you're here, then. R- Yes, I like the United States a lot. Yes, that's why I'm here, and that's why I chose the United States. If not, I would have gone to another country. $\mathrm{J}-\mathrm{Mmm}$.

R- Yes. Imagine, I had three kids. 18 years old. I came to the United States. Me, alone. 
24 J- Wow. How difficult.

25 R- Very, very, very difficult. But, nothing impossible. When you want

26 [something] and have the dream, you do make it a reality.

In conclusion, Rosa's complicated family life caused her to be unable to pursue education throughout most of her life. Now that her children are grown and gone, and now that her husband is no longer controlling where she can go and what she can do, she has been able to take English classes as much as possible.

Work. Rosa has held varied jobs while being in the US, including soldering, harvesting fruits, serving in a restaurant, housekeeping, managing a small business, and picking worms from the ground in orchards at night in order to sell the worms as fishing bait. After her husband absconded with the contents of her bank account and she lost her home, she had to move in with her in-laws and scramble for work to support herself, her sons who are having difficulty finding work in Mexico, and her mentally disabled daughter who is currently being cared for in a facility in Mexico.

At the time of our third interview, Rosa was working a nighttime housekeeping job and occasionally worked weekends on a farm. She planned on taking a Winter term class at Stumptown, but as spring was coming, Rosa was going to pick up more hours at the farm, and her work schedule was going to prevent her from taking more classes during the Spring term:

\section{(4.g) Excerpt from Interview \#3:}

1 R- quiero agarrar clase esta temporada más, y voy a descansar, porque se 2 viene el trabajo, entonces ya voy a trabajar. Ya no voy a tomar clases, porque 3 es mucho trabajo para mí. [...] llevando a las tres de la mañana, me voy a 4 trabajar, y regreso hasta las tres de la tarde, y de allí, tengo que hacer otro 5 trabajo que tengo en la noche, y es mucho, y no voy a aguantar, me voy a 6 morir pronto.

7 J- Sí. Sí, eso es demasiado. 
8 R- Es mucho. ¿Y te imaginas...? Si llego del trabajo del día a las tres, descanso

9 como, por decir una hora, a las cuatro tengo que comer y eso, y de allí me voy trabajar, regreso como a la una, y no duermo nada, y a las tres me tengo que levantarme allí en la mañana.

J- Oof. ¡Qué horrible!

R- Es muy pesado.

J- Sí. Sí.

R- Muy pesado. Y luego, pues, mi trabajo es por contrato, no es por horas. Tengo que apurarme para ganar, si no, no gano. Pues sí. Por eso, a veces es bien difícil para toda la gente, ¿cómo se dice? La gente inmigrante, porque aquí en Estados Unidos, no nos presumimos nadie de que tenemos dinero y venimos a estudiar. Quizás hay, a lo mejor sí hay unas personas que nomás vienen a estudiar. Pero muchas personas, la mayoría, trabajan y estudian. Y es donde, donde no tenemos el tiempo para asimilar bien lo que es el estudio, de que estamos haciendo. No hay tiempo, porque, porque uno se dedica más, los que tienen hijos, que van a la tienda, compran el lonche, el niño está llorando, el niño está enfermo, so va al hospital, y la tarea, ¿dónde se quedó? Llegan a la escuela y están apurados haciendo la tarea [laughs].

\section{(4.g) GLOSSED Excerpt from Interview \#3:}

R- I want to take a class for this season, and then I'm going to rest, because work is coming, so then I'm going to work. I'm not going to take classes anymore, because it's a lot of work for me. [...] getting up at three in the morning, I go to work, and I come home even until three in the afternoon, and from there, I have to do the other job that I have at night, and it's a lot, and I'm not going to bear with it, I'm going to die soon.

J-Yes. Yes, that is too much.

R-. It's too much. And can you imagine? If I come home from my day job at three [PM], I rest for, let's say about an hour, at four I have to eat something and that, I and from there I go to school, I come home at nine thirty from school, at ten I leave for work, I come home around one [AM], and I don't sleep at all, and at three I have to get up there in the morning. J- Oof! How horrible!

14 R- It's really tough.

15 J- Yes, yes.

R- Very tough. And later, well, my job is per contract, it's not per hour. I have to rush to earn money; if I don't, I don't earn anything. So yes. For that reason, sometimes it's really difficult for all of the people, how do you say? All of the immigrants, because here in the United States, nobody boasts of having money or that we just come to study. Maybe there are, OK, maybe there really are some people who do come here just to study. But many people, the majority, work and study. And it's where, were we don't have time to really assimilate what studying is, or what we're doing. There isn't 
24 time, because, because you dedicate yourself to rather, those who have

25 children, they go to the store, they buy lunch, the kid is crying, the kid is sick,

26 so they go to the hospital, and the homework, where did it end up? They get

27 to school and they're rushed, doing the homework [laughs].

During the term that I observed, Rosa often had to leave class early in order

to go to her night job. Therefore, Rosa's work schedule not only caused her to not be able to do her homework and therefore be even more behind in class and less inclined to participate, but also actively prevented her from attending all of the scheduled class hours, and was consequently a major cause of her non-participation.

Lack of prior education. At the time of analyzing these data, I had known Rosa for five months as her teacher and five months as a researcher. Rosa ended up in my class at Stumptown because of her lack of prior education: as a literacy student, she was struggling in her mainstream ESL classes and needed supplemental literacy instruction. I had many conversations with Rosa's main ESL teacher at the time, Pam, and we did our best to help Rosa acquire the literacy skills she needed.

At the time of this study, Rosa had been taking mainstream ESL and supplemental ESL literacy classes at Stumptown for two or three years, off and on (she wasn't very clear on the timeline, as she had taken several terms off in order to work). Of all the students in my classes, she showed the most remarkable improvement. By the end of the class, she was almost able to write a full paragraph unaided-an amazing feat for an adult student with so few years in an educational system. I neglected to ask Rosa how she first learned to read and write, but I do know that the very first formal educational setting she had ever been in was Stumptown, when she started taking English classes in her mid-40s. In only two or 
three years, Rosa had acquired much of the knowledge of "lo que es el estudio /

what school is" (or "how to 'do school,'” as Harris, K., personal communication, calls

it); knowledge that literate adults often spend more than a decade acquiring.

Despite Rosa's remarkable progress in literacy and in school knowledge, she

was still unable to fully participate in her Intermediate-Low mainstream ESL

classes. She wrote very, very slowly, and usually spent much of the teacher-led class

time painstakingly copying words from the whiteboard to her paper. When the

teacher passed out worksheets for students to do pairwork or group activities, Rosa

often had to spend twice as long as the other students reading the directions, so she missed a large portion of actually doing the activities.

Throughout our interviews, Rosa discussed "writing" almost as a casual jogger discusses "marathon running": it's something she has great respect for and maybe has dabbled in, but it's not anything that comes naturally to her. During our second interview, I asked her to describe a typical class activity to me, and she provided the following account:

(4.h) Excerpt from interview \#2:

1 R- Como ayer, es que vio que, la primera cosa que hicimos es, la, ¿cómo se

2 dice? Dictation. Nos dictó ella cosas y, diciendo, y es que, ciertas cosas

3 diciendo. Ya de allí, todo que dictó ella lo escribimos. Entonces, ya después

4 de eso, que lo acabamos de escribir, cada uno nos preguntó a cada uno cómo

5 ella dictó. Que es lo que ella dictó. Entonces, ya cada uno iba diciendo lo que

6 ella dictó. A muchos nos faltó. Lo escribimos diferente, o nos faltó el acento,

7 o cosas allí, entonces ella lo volvió a corregir, ya nosotros volvimos a borrar

8 lo que escribimos y volvemos a corregir lo que ella escribió en el pizarrón.

9 Entonces, eso está muy bien, porque así ya se da cuenta quienes lo hicieron

10 más o menos, quienes no lo hicieron bien y ya están borrando y escribiendo

11 [laughs], y cada uno de nosotros ya después que se acabó eso, ya pues, con la

12 tarea, como dijo anteayer, fueron tres páginas, y ya lo, nos preguntó a cada

13 uno de nosotros a leerlo, y a que lo leímos, lo escribió en el pizarrón, ya cómo 
ella dice qué es, entonces ya lo escribió en el pizarrón, otra vez nosotros lo borramos, y es que está mal, y digo, “¡Está bien pero eso está confuso!” Porque si tu escribistes de esta manera, y que aquí está algo mal, o que por acá está otro algo mal, tienes que borrer y escribir acá y dices ¿cuánta falla? ¿por qué está esa falla? ¿Por qué? Porque no ponemos atención, o es que más bien no lo sabemos escribir la oración. Dices, no, pues sí, tiene, tiene razón: necesitamos escribir mucho, leer mucho [laughs]. Digo, Oh my God! Hay que quitiar el trabajo, hay que no hacer nada para leer. Porque si estás trabajando, y estás pensando en tu trabajo, y estás poniendo atención a tu patrón, y que este y que el otro, y luego la maestra otra, y luego esto lo otro, la tarea esto, y los hijos en la casa otra, y la familia otra, dices, “Man!”...

\section{(4.h) GLOSSED Excerpt from Interview \#2:}

R- Like yesterday, so let's see, the first thing we did is, the, how do you say? Dictation. She dictated things to us and, saying, and it's that, saying certain things. And from there, everything that she dictated we wrote. Then, so after that, what we just wrote, every one of us asked each other what she dictated. What it was that she dictated. So, then, each one of us went around saying what she dictated. Many of us were missing [parts]. We wrote it differently, or we were missing the accent, or things like that, so she went back and corrected it again, the we went back and erased what we had written, and we went back to write what she wrote on the white board. So, that's really good, because that way you realize who more or less did it, who didn't do it well and are now erasing and writing [laughs], and every one of us then after that ended, so then, with the homework, like she said the day before yesterday, was three pages, and then she asked each one of us to read it, and after we read it, she wrote it on the white board, because she says what it is, so then she wrote it on the white board, another time we erased it, and it's because it was bad, and I say, "It's good but it's confusing!" Because if you wrote it in this way, and that here there's something bad, or that over there there's another something bad, you have to erase and write here and you say, how many errors? Why is this an error? Why? Because we don't pay attention, or more likely we don't know how to write the sentence. You say, no, well yes, it, it's right: we need to write a lot, read a lot [laughs]. I say, Oh my God! You have to quit your job, you have to do nothing else other than read. Because if you're working, and you're thinking about your job, and you're paying attention to your boss, and there's this thing and the other thing, and then another thing is the teacher, and later this other thing, and this homework, and another thing your kids at home, and then another thing is the family, you say, "Man!..."

Dictation and three pages of homework (discrete sentences on worksheets) are typical classroom activities, yet Rosa described them with a mix of frenzy and 
bafflement. Writing and erasing several things over and over in order to pinpoint unknowable errors seemed to her to be a "bien pero confuso / good but confusing" task and one that was good for recognizing how her classmates struggled as much as she did with it (see lines 8-10). This episode illustrates how some of Rosa's nonparticipation in-class was simply due to the fact that she lacked frames of knowledge for how to acquire knowledge from mundane classroom tasks.

Rosa was also uncomfortable with many classroom routines and expectations. In fact, one of the main reasons that she dropped out of her Intermediate-Mid class was that she perceived the teacher as being too strict, because the teacher had a pre-set syllabus and course calendar, she asked students to sit next to new partners every day, and she asked students to stand in front of the class and speak to the class:

\section{(4.i) Excerpt from Interview \#4:}

1 R- Sí es bonito saber de muchas cosas de lo que es eso, pero el inglés... Yo 2 entiendo que ustedes, les dan unos cierto, ciertas cosas que enseñar y es 3 todo. Porque yo veía a la maestra y ella traía su, su lista de lo que iba a 4 enseñar. Como es otra maestra del [INTERMEDIATE-MID CLASS name], 5 cuando vio las hojas, de todas las hojas, y de, de esas hojas, ella iba sacando la 6 tarea. Y de esas hojas nos estaba enseñando, y de esas hojas estaba... 7 J-Huh.

8 R- Aha.

$9 \quad$ J- ¿Y solamente trabajando con esas hojas y con nada más?

10 R- Sí. Yo tengo en la casa esas hojas. Y de allí sacaba ella cosas, y digo yo...

11 Porque ella dijo, "Esto lo que les estoy dando aquí es lo que vamos a dar entre 12 los tres meses." Ella tenía los días de, los días que teníamos que hacer los 13 exámenes, los días que teníamos que estudiar y los días que no, los días que 14 íbamos a salir temprano y los días que no, y todo eso. Por una parte sí está 15 bien, pero por otra parte no está bien porque, muy de prisa. Y “¡Párense en 16 frente!” y “iQuiero oír que hablen bien!” y “¿Que no estén allí, que tengan allí 17 lo que están...” No, “Hablen bien claro, y rápido, y recio!” Y, “Oh,” decía yo, 18 “Oh, man, ¡no puedo!” [R laughs]

19 J- Aha, aha. 
R- Sí, sí, pero sí. Trataba yo con nervios, pero sí trataba yo, de hablarlo. Y otras, la... hay unas, Japaneses? Unas Japaneses, unas Vietnameses, y unas, que hablan "Mii, mii, mii" [mimics talking with lips very close together and speaking in a quiet, high voice]. ¡No! Se enojaba bien la maestra.

$$
\text { J- Ooh, wow. }
$$

25 R- Sí. Iba y le decía, “¡Tienes que hablar así! ¡Que se oiga la voz desde la pared! ¡Que retumbe la voz en la-!” Y volvió a repetir, “¡No! ¡Tienes que hablar así!” Tres, cuatro veces tenía que estar- ¡Sí! Brava, esa maestra.

28 J-Wow.

R- Dije, no... I don't, ¡no me gusta eso! Dije, “No, ¡yo me voy, yo me voy, yo me voy, yo me voy, no quiero estar!" [laughs]

$$
\text { J- Ooh. }
$$

$\mathrm{R}-$ ¿Sí?

J- Wow.

R- No. Desde que entraba yo en la puerta, dije, [...] [J laughs]. Sí, y every day, tenías que cambiar con diferente compañero. No, no todo el tiempo te sientas con la misma compañera.

J- Oh, OK.

R- Un día con uno, otro día con otro, y otro día con otro.

J- Y ¿no le gustó hacer esto? hombre, una mujer. Un hombre, una mujer. J- Oh, wow.

R- ¡Sí!

J- ¿Por qué? ¿Dijo por qué?

R- Pues no. Nomás ella quería así. J- Y ¿no le gustó hacer esto?

R- No. Y las mujeres que se sentaban las dos, no, no no. "Tú te vas a sentar con a fulano, tú te vas a sentar junto a fulano." Así nos ponía.... Notros [=nosotros] llegábamos, nos sentábamos así, y no no no. "Tú allá y tú allá." Aunque escogieras con otro, te cambiaba con otro. Así siempre te... ¡A esta señora no le gusta nada! [laughs]

J- [laughs] Oh, wow.

R- Dije yo, maybe en su casa es muy estricta [laughs] ¡Se ve! J- Ooh, wow.

$$
\text { R- [sighs] }
$$

J- ¡Qué estrés!

R- Demasiado. Demasiado. Y yo con mis problemas, no. Dije “Neeh.”

\section{(4.i) GLOSSED Excerpt from Interview \#4:}


papers, of all the papers, and out of, out of those papers, she was getting the

6 homework. And from those papers she was teaching us, and from those

7 papers she was...

8 J-Huh.

9 R- Aha.

10 J- And only working with those papers and with nothing else?

11 R-Yes. I have those papers at my house. And from there she took things, and

12 I say... Because she said, "What I'm giving you here is what we are going to do

13 in these three months." She had the days of, the days that we were going to

14 do the tests, the days that we had to study and the days that we didn't, the

15 days that we were going to leave class early and the days that we weren't,

16 and all that. On one hand it's good, but on the other hand it isn't good

17 because, very rushed. And "Stand up in front!" and "I want to hear you speak

18 well!" and "Don't be like that, you have to have what you're..." No, "Speak clearly, and quickly, and loudly!" And "Oh,” I said, “Oh, man, I can't!" [R laughs] J- Aha, aha.

R- Yes, yes, but yeah. I tried nervously, but I did try to speak it. And others, the, there are some, Japaneses? Some Japaneses, some Vietnameses, and some, that speak "Mii, mii, mii" [mimics talking with lips very close together and speaking in a quiet, high voice]. No! The teacher got really mad. J- Ooh, wow.

R- Yeah. She went and she told them, "You have to talk like this! Your voice should reach the wal! Your voice should echo-!" And she repeated again, "No! You have to talk like this!" Three, four times she had to be-yes!

Fierce, that teacher. J- Wow.

R- I said, no... I don't, I don't like that! I said, “No, I'm leaving, I'm leaving, I'm leaving, I'm leaving, I don't want to be here!" [laughs] J- Ooh.

35 R- Yeah?

36 J-Wow.

37 R- No. From when I walked in the door, I said, [...] [J laughs]. Yes, and every

38 day, you had to change with a different classmate. No, the whole time you couldn't sit with the same classmate.

43 J- And you didn't like doing that?

44 R- [overlapping] And never with two women. One man, one woman. One

45 man, one woman. One man, one woman.

46 J- Oh, wow.

47 R- Yeah!

48 J- Why? Did she say why?

49 R- Well no. She just wanted it like that. 
$50 \quad$ J- And you didn't like doing that?

51 R- No. And the two women that sat together, no, no, no. "You are going to sit

52 with so-and-so, you are going to sit next to so-and-so." She put us like that...

53 We would arrive, we would sit like that, and no no no. "You there and you

54 there." Even if you would choose a different one, she would change you with

55 a different one. Like that you always... this teacher doesn't like anything!

56 [laughs]

57 J- [laughs] Oh, wow.

58 R- I said, maybe in her house she's very strict [laughs] It shows!

59 J-Ooh, wow.

60 R- [sighs]

61 J- What stress!

62 R- Too much. Too much. And me with my problems, no. I said, "Neeh."

These excerpts, as well as hints dropped in others (see 3.b and 4.a above and 4.m below), show Rosa's quandary with hungering to learn in a school that does not support her slow path toward acquiring the knowledge of how to "do school." Based on the data from these interviews and from my observations of Rosa in her Intermediate-Low class, I would contend that the most salient, most pressing factor of Rosa's non-participation in class was her lack of formal education.

Summary of social context of her life. To summarize this section, the social context of Rosa's life has provided Rosa with little opportunity to participate in English classes. Her family actively prohibited her from getting an education (her family forcing her to work in the fields from ages 5-18 while living in Mexico, her three children taking up most of her time for the next two decades in the United States, and her husband prohibiting English classes for another decade), her job routinely prevented her from attending class, and her lack of formal education preclude her from taking an active role when she was actually able to be in class.

\section{Factors Affecting Rosa's Investment in Learning English}

The second focal point in my study was Rosa's investment into learning 
English. Her desire to learn English has been influenced by her interactions with strangers in the US and her legal issues in the US, both of which can be summarized by her desire for self-advocacy. (Note: there were 8 codes that directly or indirectly influenced Rosa's investment in learning English, as can be seen in Figure 2 in Chapter 3; however, I will only be discussing the two most central codes, as the others have either been discussed above or did not serve to answer the guiding question of this thesis.)

\section{Interacting with strangers in the US outside of the classroom. One}

prominent theme throughout our interviews was Rosa's interactions with American English speakers outside of the classroom. Rosa had a rich and varied social life. As discussed above, she very much enjoyed interacting with her classmates at Stumptown. She also had many friends in the Latino community, and she would go out to movies or go out dancing or have parties at their houses. The community that she sought and lacked, however, was that of American English speakers. Rosa lamented the lack of accessibility to English speakers at home and at work, saying that her in-laws (who are all speakers of English, and significantly for Rosa, who wants to sound more like Americans, her in-laws are all speakers of English as a first language) are too busy in their daily lives to ever talk with her. In addition, at her current job as a nighttime cleaner of local businesses, the only person she gets to speak to in English is the security man (she sometimes accidentally mis-types the building's alarm code and the security man calls her up to verify her identity).

Rosa wanted more interactions with English speakers, but she felt awkward initiating conversations in many places, and she often described being laughed at or 
being made fun of for her pronunciation. During our fourth interview, Rosa

discussed the pressing need to keep learning English, even though she had already dropped out of Stumptown:

\section{(4.j) Excerpt from Interview \#4:}

1 R- también tengo otra amiga también burra como yo [laughs]

2 J - No, no, no.

3 R- Ella también se salió de la [NAME OF INSTITUTION].

4 J- Ah, OK.

5 R- Sí, pero, sí me dice que está buscando también a ver si hay otras clases

6 para que ayuden a ella. Le digo, "Sí, lo que pasa es que no estamos

7 buscando," le digo, "a ver si hay. Podemos ir a otra escuela también si

8 queremos, pero queremos que sólo el inglés nos entre en la cabeza, y no

9 hacemos nada: ni escuchamos música en inglés, ni escuchamos la radio en

10 inglés, ni hacemos nada en inglés, y queremos aprender inglés, entonces

11 ¿cómo vamos a aprender?" [laughs]

12 J - [laughs] Aha, aha aha.

13 R- Pero ella sí escribe un poco pero no habla. No habla nada. "Tienes que

14 hablarlo," le digo. "No, no," “[...] ese, aunque no le van a salir bien las

15 palabras," le digo, "hay gente que se burlan, pero tú, hazte cuenta que no

16 hemos [...] nada de seguir hablándolo porque necesita practicarlo," le digo.

17 "Yo, yo sí entiendo mucho," le digo, "entiendo, pero no puedo hablarlo,

18 contestar rápido en las conversaciones. Pero trato de hacerlo porque ¿quién

19 me va a ayudar? Nadie me va a ayudar," le digo, "Estoy sola aquí, ni ya tengo

20 mis hijos. No tengo a nadie. Yo solita estoy aquí." Le digo, "Ni siquiera un

21 esposo que..."

22 Dice, "¿Tú te quieres?" Dice, "Búscate un güero paque se-" [laughs]

23 Digo, “No es fácil!” Le digo, “ ¡Eso no es fácil! ¡Es más problemas pa mí!”

24 J - Aha, aha [laughs]

25 R-Búscate un güero. Sí, sí me dice, “¡Búscate un güero paque así aprendes

26 rápido!"

27 "No... Eso no es una buena idea," le digo, "Yo tengo más problemas en mi

28 vida con eso," le digo, "Sí, diferente cultura, diferente comida, diferente-

29 ooh!" le digo, no.

30 J [laughs] Aha, aha.

31 R- "No, eso no sirve," le digo yo. [laughs] Así es cómo te digo, si te vas por

32 México, búscate un mexicano pa aprender mejor español pero no es la de allí, 33 vayas a estudiar español," [laughs]

34 J- [laughs] Yo quiero seguir aprendiendo. Yo quiero seguir, porque sí, todavía

35 sí es difícil.

36 R- Eso sí, es cómo, por decir, si quieres civilizarte a las palabras civilizadas,

37 como de formas [...] de abogados, legales, pues, como dice la maestra, sí, tiene 
que, porque, pues, [...] como quiera. Ya, sí de leyes, es mucho de diferente J- Sí, sí, sí

R- Complicada.

J- Sí.

R- Sí. Que yo decir, yo digo, no...Para que yo quiera ser algo más así, no, porque ya a mi edad, y ya. Sí quiero saber, pero, cositas sencillas, entender lo que es que significa, que hay que contestar cuando te dicen esto, o que no hay que contestar, porque a veces, dicen una cosa, y si uno no debe de decir esto, y lo dices, pues, te metes en problemas graves.

\section{J- Mmhmm.}

R- Sí. Así es.

J- Entonces, cuando está hablando en inglés, ¿hay algunos lugares o algunas situaciones, cuando uno-cuando usted se siente que tiene coraje? Que "iYo sí puedo hablar inglés!" que “¡Yo sí lo puedo hacer bien!” R- Sí, pero, ¿cómo te diré? Pues, ha aprendido-he aprendido inglés, pero siento que no es lo suficiente. Porque, la otra vez, fui a un lugar de maquillajes, cuando se juntan muchas mujeres de diferentes países, y pues, allí, estaban preguntando todo en inglés. Y hubo una señora que abrió su boca y no lo dijo bien, y todos se rieron, todos se burlaron. Entonces, yo... pues, dices, te da miedo abrir tu boca, porque dices, "Wow, ¿qué pasa si digo algo mal?" Oh my God. Qué vergüenza. Entonces, yo lo que hice, le dije, "Sabe que, yo necesito una persona que hable español e inglés, porque yo no puedo hablar inglés. Entiendo pero no lo puedo hablar, y no quiero que se burlen de mí," le digo. Entonces sí ya pusieron una persona. Pero, su español, y su inglés también igual que el mío, pero bueno, ya es una persona que está ayudando la compañía donde ellos están trabajando. Pero si uno no es nada allí, empiezas a hablar, y pues todos están poniendo atención a que tú dices, y ¡la vergüenza!

\section{J- Sí, sí sí.}

R- Sí. La vergüenza, porque siente uno bien mal; dices no... Tengo miedo a abrir mi boca. En eso sí, sí la verdad, tengo no [...] porque no, no es para nomás... [laughs]

J-Pero ¿hay lugares, hay otras situaciones en que usted puede, o se siente que no tiene vergüenza de hablar en inglés?

R- No, yo sí lo hablo... sí, a veces... las tiendas, los restaurantes, sí. So, hay veces hay cosas que quizás no sé cómo se llaman, pero, pues, les digo de otro nombre, o les señalo o algo así-la cosa es de iniciar. Porque si nomás te quedes como un bebé allí [makes baby noises], no, pues tampoco. Sí, tiene uno que abrir la boca por algo.

\section{(4.j) GLOSSED Excerpt from Interview \#4:}

1 R- I also have another friend who's stupid like me [laughs]

2 J - No, no, no.

3 R- She also quit going to [NAME OF INSTITUTION]. 
$4 \mathrm{~J}-\mathrm{Ah}, \mathrm{OK}$.

5 R- Yes, but, she tells me that she's also trying to see if there are other classes

6 that can help her. I tell her, "Yes, what happens is that we're not looking," I

7 tell her, "Let's see if there is something. We can go to another school also if

8 we want, but we want English to simply enter into our heads, and we don't

9 do anything: we don't listen to music in English, nor do we listen to the radio in English; we don't do anything in English, and we want to learn English, so how are we going to learn?" [laughs]

J - [laughs] Aha, aha aha.

R- But she does write a bit but she doesn't speak. She doesn't speak at all. "You have to speak it," I say. "No, no," "[...] that, although the words aren't going to come out well," I tell her, "There are people who make fun of you, but you, realize that we haven't [...] nothing to keep speaking it because we need to practice it," I tell her. "I, I do understand a lot," I tell her, "I understand but I can't speak it, answer quickly in conversations. But I try to do it because who's going to help me? Nobody's going to help me," I tell her, "I'm alone here, land I don't even have my children. I don't have anyone. I'm alone here." I tell her. "Not even a husband who..." White man] so you-" [laughs].

I say, "It's not that easy! That would be more problems for me!" J - Aha, aha [laughs]

R- Look for a güero. Yes, yes she tells me, "Look for a güero because that way you'll learn quickly!"

"No... That's not a good idea," I tell her, "I'll have more problems in my life with that," I tell her, "Yes, different culture, different food, different-ooh!" I tell her, no.

J [laughs] Aha, aha. R- "No, that won't work," I tell her. [laughs] So it's like I tell you, if you go to Mexico, look for a Mexican [man] to learn better Spanish but it's not from there, going to study Spanish," [laughs] J- [laughs] I want to keep learning. I want to keep on, because yes, it's still difficult.

R- That's true, it's like, to say, if you want to civilize yourself to the civilized words, like of the forms [...] of lawyers, legal things, well, as the teacher says, yes, you have to, because, well, [...] as you like. So, yes of laws, it's very different. J- Yes, yes, yes. R- Complicated. J- Yes R- Yes. That is to say, I mean... So that I would want to be something more, no, because now at my age, that's it. Yes I want to know, but, simple things, understand what it is that it means, what I should answer when they tell you this, or what I shouldn't answer, because sometimes, they tell you one thing, and if you shouldn't say something, and you say it, well, you can get yourself 
49 into big trouble.

$50 \mathrm{~J}-\mathrm{Mmhmm}$.

51 R- Yes. It's like that.

52 J-So, when you're speaking in English, are there some places or some

53 situations when one-when you feel like you have courage? Like "Yes I can

54 speak English!" like "I really can do it well!"

55 R- Yes, but, how can I tell you? Well, it's learned-I've learned English, but I

56 feel like it's not enough. Because, the other day, I went to a makeup place,

57 when a lot of women from different countries get together, and well, there,

58 they were asking everything in English. And there was a woman that opened

59 her mouth and didn't say it well, and everyone laughed, everyone made fun

60 of her. So I... well, you say, it makes you scared to open your mouth, because

61 you say, "Wow, what happens if I say something bad?" Oh my God. Such

62 shame. So, what I did, I told them, "You know what, I need a person who

63 speaks Spanish and English, because I can't speak English well. I understand

64 but I can't speak it, and I don't want them to make fun of me," I tell them. So

65 they did give me a person. But, her Spanish, and her English also was the

66 same as mine, but well, she's now a person who is helping the company

67 where they are working. But if you aren't anything there, you begin to speak,

68 and then everyone is paying attention to you and to what you're saying, and

69 the shame!

70 J- Yes, yes yes.

71 R- Yes. The shame, because you feel really bad; you say no... I'm afraid to

72 open my mouth. In that yes, yes the truth, I don't have [...] because no, it's

73 not for only... [laughs]

$74 \mathrm{~J}$ - But are there places, are there other situations in which you can, or you feel

75 like you aren't ashamed to speak in English?

76 R- No, I do speak it... yes, sometimes... the stores, the restaurants, yes. So,

77 there are times when there are things that maybe I don't know the name of,

78 but, well, I call them by another name, or I gesture to them or something like

79 that - the thing is to begin. Because if you only stay there like a baby [makes

80 baby noises], no, well that neither. Yes, you have to open your mouth for

81 something.

This exchange shows several noteworthy things. Regarding her identity,

Rosa seems to be exhibiting a tension between her desire to fit into English-

speaking communities, but also a fear of changing or losing her way of life that is not

associated with U.S. English (see line 29 above: "diferente cultura, diferente comida, diferente-ooh! / different culture, different food, different—ooh!"). In addition, 
is bilingual, she said she needed "una persona que hable español e inglés / a person who speaks Spanish and English," lines 62-63) to help increase her social capital in this particular situation). Furthermore, Rosa provided evidence that she was not able to claim a voice in a social situation in which she didn't already have symbolic capital (Bourdieu, 1991; “si uno no es nada allí / if you aren’t anything there," line 67): the woman working at the makeup place had equal linguistic abilities to Rosa, but was able to claim the right to speak whereas Rosa was silenced.

Regarding her language-learning path, this exchange shows that Rosa acknowledged that she needed to be actually doing something-participating in English-speaking communities-in order to keep learning. She needed to find a socially acceptable entrance to a community of English speakers, which her friend suggested she might find by marrying a White American man: such a husband would give her access to the networks she lacked. As was practical, Rosa rejected this suggestion, but she still laughed lightheartedly at the idea from her friend (who, significantly, is at the same educational level as Rosa), and even advised me to try the trick if I decided to go to Mexico and keep learning Spanish. In addition, as evidenced above and discussed further in the next section, Rosa was constantly looking for how to say things in "civilizadas / civilized" (line 37) ways or to understand how to stand up for her legal rights; she quickly went on to say that she wasn’t looking to “yo quiera ser algo más así / be something more" (line 44), but simply wanting to understand what she should or shouldn't say in certain situations when she could get into trouble. Finally, she expressed the perennial quandary of language learners everywhere: how to get better at speaking a language when the 
speakers of that language laugh at your poor speaking.

In sum, Rosa's interactions with American English speakers were a major push for her to learn English. She both felt compelled to seek out English-speaking communities as well as felt rejected by those same communities. While this "lack of return on her investment" (Norton, 2001, p. 166) prevented her from practicing English in many opportunities (as in 4.j above), she refused to be positioned into being a "bebé / baby" who can only make baby noises and she continued to "abrir la boca / open [her] mouth" to claim her right to speak in many other situations.

Legal/Police Issues. The most salient, most pressing reason for Rosa to learn English was to learn how to defend herself in interactions with the law in the US. Her interactions with strangers, as discussed above, were a sign to her that she needed to learn to speak well enough (to pronounce English well enough), to not be laughed at. However, her interactions with the police and with legal issues were a major driving force in her life to learn English well enough to not be arrested, beaten, or killed. Throughout the four interviews, Rosa described a fear of the police: she had witnessed many crimes in her neighborhood in Portland, but she felt barred from reporting the crimes or being a witness because her English wasn't good enough to explain what she saw well enough, or, in her words from (4.e) above: "muchos de nosotros latinos, mejor no abrimos la boca, porque tenemos miedo que ese caso, que en vez de que, que uno... ayuda a la persona, al contrario a nosotros nos meten a la cárcel / Many of us Latinos, it's better that we don't open our mouths, because we're afraid that in that case, that instead of, of helping the person, on the contrary they put us in jail." She described one incident in her 
apartment building where several youths had indeed been mistakenly arrested (according to Rosa) and charged with murder after they were found passed out near someone who had been shot. The youths spoke no English, and Rosa recounted how as soon as they were arrested and charged, there weren't even interpreters in the jails, so they had no way of standing up for themselves, which Rosa described as evidence for her own need to learn English to defend herself. Rosa described seeing other incidents: gunshot wounds, car accidents, fights, and feeling the need to flee in the other direction because she couldn't defend herself.

However, she also described several incidents in which she was indeed able to claim a voice and speak up for others when they were in danger. At one point, Immigrations and Customs Enforcement (ICE) raided her workplace, and she recounted how one of her coworkers spoke no English; when he failed to follow the officer's instructions, the ICE officer threw him on the ground and began to kick him in the stomach (see Read, 2002, on the abuses of Portland's officers for Immigration and Naturalization Service, ICE's parent agency). At that point, Rosa stepped in and re-phrased what the ICE officer had said to her coworker so that he understood:

\section{(4.k) Excerpt from Interview \#2:}

1 R- Y un señor no entendía y le estaban diciendo "Haz esto. Hazlo." Y yo lo

2 [...] que estaba diciendo pero yo lo dije de otra manera para que el señor lo

3 entendiera. Y sí lo entendió y ya lo hizo. Entonces, el, el, [...] dijo, “¿Tú hablas 4 bastante inglés?" Le digo, "No. Just poquito. No, no sé mucho." "Oh," dice, 5 "Porque si entiendes un poco, y sabes lo que estoy diciendo a ellos, diles 6 porque no me entienden. Yo lo voy a decir una vez, no voy a decir cada rato." 7 Ellos hablan así. Son del gobierno. Son como los [...], como, si entiendes, si 8 no entiendes, te matan a ti. Y ese señor, lo patearon. [...] la panza. Y ya no 9 podía ni respirar, y estaban diciendo que se parara con sus manos atrás, y él 10 no lo hacía porque no entendía, no sabía lo que le estaban diciendo. Digo, lo 11 tanta gente que nosotros somos, como, ¿cómo se dice? que estamos en este 
12 país.... Entonces, ese es, ese es el trato que yo tengo conmigo mismo.

13 Conmigo misma. A saber el idioma. Yo quiero saber el inglés.

\section{(4.k) GLOSSED Excerpt from Interview \#2:}

1 R- And one man didn't understand and they were telling him, "Do this. Do it."

2 And I [...] him what they were saying but I said it in another way so that the

3 man would understand. And he did understand and then he did it. So the,

4 the, [...] said, "You speak a lot of English?" I tell him, "No, just a little. No, I

5 don't know a lot." "Oh," he says, "Because if you understand a little, and you

6 know what I'm telling them, tell them because they don't understand me. I'm

7 going to say it one time, I'm not going to keep repeating myself." They talk

8 like that. They're from the government. They're like the [...], like, if you

9 understand, if you don't understand, they kill you. And that man, they kicked

10 him. [...] the stomach. And he couldn't even breathe any more, and they

11 were telling him that he should get up with his hands back, and he didn't do it

12 because he didn't understand, he didn't know what they were telling him. I

13 say, as many people as we are, like, how do you say? who are in this

14 country.... So, that's, that is the contract that I have with myself. With myself.

15 To know the language. I want to know English.

Rosa made fewer statements more powerful than that of making a contract

with herself as a result of her incidents with the police and with the law in the US.

She gave one further example of how her success in defending a friend against the

law gave her the power to speak and the power to keep learning:

(4.l) Excerpt from Interview \#3:

1 R- Entonces esa fue la razón, el impulso de buscar el inglés. Porque muchas

2 cosas te culpan, una cosa que tú no hicistes, te lo culpan. Si tú no te sabes

3 defender, si dices, "Oh yes, oh yes, yes yes," y jno es "yes," sino tienes que

4 decir "no"!

5 J- ¡Aha!

6 R- ¿Sí?

7 J- ¡Aha!

8 R- Y entonces, digo, porque yo he visto a mis amigas que dicen, "Yes."

9 “Por qué estás diciendo "yes" si te están diciendo que [...] algo que no

10 debes?" Llevé a una amiga hace dos años a la corte en Vancouver. Porque le

11 dieron ticket. Venía muy recio y [...] y ella no tiene licencia. Pues yo, este,

12 ¿cómo se dice? rescaté el carro, pero a ella le iban a llevar a la cárcel, porque

13 estaba manejando sin ID, sin aseguranza, sin el carro no estaba en su nombre.

14 Yo venía con ella, y el policía muy racista, muy racista, muy racista. 
Le preguntó su nombre, y le dice, "Dame sus papeles." Y le dio sus papeles.

"Oh no, estos papeles, tú los comprastes, no sé dónde los comprastes" le dijo el policía. Ya era viejito ya era un señor policía viejito, pero andaba en moto. Y, le, "Ya," yo le dije, "Excuse me, sir," le digo, "Yo no... yo," le digo, "quiero hablar por ella porque ella no sabe nada de inglés."

[mimicking shouting] “¿Por qué no aprenden inglés? ¡Están en Estados Unidos!” y quien sabe qué estaba empezando a decir.

Le digo, "I'm sorry, I'm sorry," le digo.

Ya entró en razón el señor, y me dijo, “'Tú tienes licencia?”

Le digo, "Sí."

[mimicking shouting] “¡iY por qué le digas a manejar a ella!?”

Le digo, "Te puedo explicar," le digo. "Mira, una cosa, no es mi carro. Otra cosa, yo vengo de [NAME OF BUSINESS]. Porque yo no quiero ir manejando, no tengo aseguranza."

"No, pero tienes licencia, debes de manear. Súbete a manejar. Y a ella, que se vaya, pues, ya la voy a esposar."

Le dije, "No, pero ¿por qué la vas a esposar si únicamente venía recio y es todo? ¡Que pague la multa! Si hay otras personas que andan vendiendo droga, andan haciendo-matando-y ¿por qué no sigues esa gente? ¿Por qué nosotros que, que venimos del trabajo? Nosotros venimos del trabajo. ¿Por qué nos, nos [...] hacer eso?" Y ella estaba allá llorando, porque ¡tiene cinco hijos! Y veníamos del trabajo cansadas, con hambre, con sed. Y todavía maltratándonos el policía. Le, ya, después, ya pues se controló, y todo, [...] ya lo puso a mí, [...] mi amiga, nomás le dio ticket, la corte, fui a la corte con ella, después de lunes y algo fui a la corte con ella. Tenía intérprete, pero a veces el intérprete habla muy rápido, y para que entienda rápido eso, yo me paré junto de ella, y le dije, "Sabes qué, pues esto, esto pasó, y yo venía con ella, y el policía se portó muy mal con nosotros, y así y asá,” y, porque el señor, la, el viejo ese, el señor ese [laughs] no quería bajar el precio del ticket. Tenía que pagar $\$ 800$.

$\mathrm{J}-$ ¡800!

R- 800 porque en un área que es a 70, ella venía 5 más. 5 millas más. Y el señor quería que pagara 800.800 y algo. Como ochocientos sesenta algo. Y ya fue que discuté yo, "I'm sorry," le digo, "Yo no sé hablar mucho inglés, pero espero que me entiendan." Le dije, "Porque nosotros andamos trabajando," le dije, "estamos viniendo de la [...]." le digo. "Ella venía un poco recio porque su niño estaba bien enfermo, y su esposo le estaba llamando por teléfono, estaba [...] el niño estaba bien enfermo. Y ella venía muy recio. Y tenemos los comprobantes, no es mentira."

Y entonces ya fue que dijo el señor, “OK,” dice, "Si es así, y tienen los comprobantes..." Ya íbamos a pasar los comprobantes. "No los necesito. Te creo," dice. "OK," dice. "OK," dice, "El precio va ser de doscientos setenta y algo." ¿Imagínate?

$58 \mathrm{~J}-¿$ ¿chocientos a doscientos y algo?

59 R- ¡de bajo! 
J- Wow.

R- Dije, yo “¡Wow, mi inglés, sí, se habla!” [laughs] dije. J- ¡Sí!

R- ¡Oh, man! [laughs] Pero yo no sé de dónde saqué el inglés. Yo no sé hablar mucho, pero sí me entendió. Y eso digo, "Oh, no, eso me da más valor, más fuerzas para yo aprender más cosas." Yo sé que no soy una persona joven para aprender rápido, pero despacio, lo voy a hacer.

\section{(4.I) GLOSSED Excerpt from Interview \#3:}

R- So that was the reason, the impulse to seek out English. Because a lot of times they blame you for something that you didn't do; they blame it on you. If you don't know how to stand up for yourself, and you say, "Oh yes, oh yes, yes yes," and it's not "yes," but instead you have to say "no"!

J- Aha!

R- Right?

J-Aha!

R- So then, I say, because I've seen a lot of my friends who say, "Yes," I say, "Why are you saying 'yes' if they're telling you that [...] something that you shouldn't do?" Two years ago, I went with a friend to court in Vancouver, because they gave her a ticket. She was going really fast and [...] and she didn't have a license. So I, um, how do you say, I rescued the car, but they were going to take her to jail, because she was driving without ID, without insurance, the car wasn't in her name. I was going with her, and the policeman was very racist, very racist, very racist.

He asked for her name, and he tells her, "Give me your papers." She gave him her papers. "Oh, no, these papers, you bought them, I don't know where you bought them," the policeman told her. He was an old man, he was already an old policeman, but he was riding a motorcycle.

And I said to him, "Excuse me, sir," I say, "I don't, I," I say, "I want to speak for her because she doesn't know any English." [mimicking shouting] "Why don't you learn English? You're in the United States!" and who knows what else he was starting to say. I tell him, "I'm sorry, I'm sorry," I tell him. Then the man became reasonable and he told me, "Do you have a license?" I tell him yes. [mimicking shouting] "And why do you let her drive?" I tell him, "I can explain," I tell him. "Look, one thing, it's not my car. Another thing, I'm coming from [NAME OF BUSINESS]. Because, I don't want to drive, I don't have insurance."

"No, but you have a license, you should drive. Get up in the driver's seat. And she should get out of the car, I'm going to handcuff her." I told him, "No, but why are you going to handcuff her if the only thing she was doing was driving too fast and that's it? Let her pay the fine! If there are other people out there who are going around selling drugs, who go around doing-killing - and why don't you follow those people? Why us, who are 
coming from work? We were coming from work. Why are you doing this to us?" And she was there crying, because she has five children! And we were coming from work, tired, hungry, and thirsty. And all that time the policeman was mistreating us.

She got control of herself, and everything [...] I put my [...] my friend, they only gave her a ticket, the court, I went to the court with her, after Monday or something I went to the court with her. She had an interpreter, but sometimes the interpreter speaks very fast, and to quickly understand that, I stood next to her, and I said, "You know what, well this and this happened, I was going with her, the policeman behaved very badly with us, and this, and that," and because the man from the, that old man [=the judge], that man [laughs] didn't want to lower the price of the ticket. She had to pay $\$ 800$. J- 800 !

49 R- 800 because she was in an area that's 70, she went 5 over. Five miles [=an 50 hour] over. And the man wanted her to pay 800-800 and something. Like 51860 something. And it was then that I argued, "I'm sorry," I told him, "I don't 52 know much English, but I hope you understand me." I told him, "Because we 53 were coming from work," I told him, "We were coming from the pharmacy," I 54 told him. "She was going a little fast because her son is really sick, and her 55 husband was calling on the phone; he was [...] the son was really sick. And 56 she was going home really quickly. And we have the receipts, it's not a lie." 57 And it was then that the man said, "OK," he says, "If it's like that, and if you 58 have the receipts..." We were going to pass him the receipts. "I don't need 59 them. I believe you," he said. "OK," he says, "The price is going to be 270

60 something." Can you imagine?

61 J- 800 to 200 something?

62 R- Lowered!

63 J- Wow.

64 R- I said, "Wow, I do know English, I do speak!”

$65 \mathrm{~J}-$ Yes!

66 R- Oh, man! [laughs] But I don't know where I got that English from. I don't 67 know how to say a lot, but he did understand me. And for that reason, I say, 68 "Oh, no, that gives me more bravery, more strength for me to learn more 69 things." I know that I'm not a young person to learn quickly, but slowly, I'm 70 going to do it.

In both (4.k) and (4.l) above, Rosa acted as a language broker, using her knowledge of English and Spanish to successfully navigate difficult and high-stakes circumstances. Rosa's strength allowed her to use her language skills (even though she repeatedly claimed a low English ability) to advocate for others.

Rosa claimed her right to speak in situations where the legal system was 
attempting to silence her; these acts of standing up for herself and her friend gave her even more desire to learn English and made her redouble her investment into her learning.

\section{Summary of the factors affecting Rosa's investment into learning}

English. Rosa's interactions with strangers and with the law have both greatly influenced her desire to learn English through her wish for self-advocacy and to stand up for herself and others.

\section{Discussion of identity \& agency}

Finally, I conclude with discussion on Rosa's comments on her own identity and agency. While completing axial coding of these interview data (see Chapter 3), it became clear that Rosa's descriptions of her identity and of her agency were conditions under which the other codes operated. Rosa's desire to move from her current identity position of "burra / stupid" to her imagined identity position as "preparada / educated" and "astuta / clever" were a major factor in shaping her investment into learning English as well as her non-participation in the classroom. Her agency in seeking self-advocacy was intimately tied to her desire to learn English and to be an English-speaking person able to stand up for herself to the authorities.

Agentively investing in an imagined identity. Because of her lack of formal educational knowledge, Rosa characterized herself as "burra" (slow/stupid) several times throughout our interviews. Rosa also repeatedly stated that she didn't know English, even though she was able to successfully act in high-stakes encounters while speaking in English, as shown by (4.k) and (4.1) above. 
Throughout the interviews, Rosa characterized herself as both a fixed entity ("tú sabes que uno es como Dios ya lo, lo trajo al mundo / you know you are as God brought you into the world," Interview \#1) and a confused, stupid one ("no puedo mentir ni te puedo decir 'o soy de aquí o soy de allá.' No sé de dónde soy / I can't lie and say 'I'm from here' or 'I'm from here.' I don't know where I'm from” from Interview \#1 and "Am I estupid, or what? / Am I stupid, or what?" from (4.m) below). She described the difficulty of being uneducated thus:

\section{(4.m) Excerpt from Interview \#1:}

1 R- ... el problema de nosotros los inmigrantes aquí en Estados Unidos, se me

2 hace que es bastante difícil decir uno no está estudia-[...] [G is saying

3 EIEIIliiay]. Esa es la razón más grande. [G- MMMM] Cuando uno está

4 preparado es más fácil porque ya como vas como dando paso a todo. Y

5 muchas palabras son similares. [G- Pa,pa,pa] Y si tú no estudiastes... sí, por

6 ejemplo yo no estudié. ¡Muchas palabras yo no sé qué significan en español!

7 Ni lo sé escribir tampoco. Y digo yo, digo yo, yo no puedo entender. El año

8 pasado llegó una-dos muchachos con su mamá. Y la señora está burra igual

9 que yo, pero la señora está preparada, y yo pienso que tiene que más, escribe

10 más inglés, que yo. Pero los muchachos, como son muy preparados en

11 México, jahorita ya saben hablar bien inglés! Y me feel like como, jay! Am I

12 estupid, or what? [Laughs.]

\section{(4.m) GLOSSED Excerpt from Interview \#1:}

1 R- ... we immigrants here in the United States have the problem, I think it's 2 really difficult to say you haven't gone to school-[...] [G is saying EIEIIIiiay]. 3 That's the biggest reason. [G- MMMM] But when you have gone to school it's 4 easier because you already, like, are going step by step. And a lot of words 5 are similar. [G- Pa,pa,pa] And if you didn't go to school... yes, for example, I 6 never went to school. I don't know what a lot of words mean in Spanish! And 7 I can't write them, either. And I say, I say, I can't understand. Last year a, two 8 boys arrived with their mother. And the woman is stupid just like me, but 9 the woman is educated, and I think that she has more, she writes more 10 English, than me. But the boys, because they were very educated in Mexico, 11 now they know how to speak English well! And I feel like, ay! Am I stupid, or 12 what? [Laughs.]

This feeling of being stupid and being unable to learn did not hinder Rosa 
from attending class or attempting to participate in class; instead, as I have demonstrated above, Rosa's non-participation in class was due to the realities of her lack of formal education, her relationship with her teacher, the institution of Stumptown School, and other factors. Instead, this identity positioning as "stupid" seemed to be a major motivating factor for Rosa to seek out English; by learning English and becoming educated, she would no longer be "burra / stupid." The biggest reason for Rosa to invest in English was her desire for self-advocacy; I contend that this investment in English was also an investment in a future self that would be able to stand up for herself and others.

Rosa is working to define her own future identity as a self-advocate, but she was constantly being denied that position by the teacher refusing to help Rosa succeed in the class, by the school system kicking her out, by strangers laughing at her, and by the negative encounters with the law. These interactions convinced Rosa that her new self with a new voice is necessary.

Rosa was incredibly invested in her future self who would be able to defend and stand up for herself and others and who would be able to articulate herself in large institutions like legal and school systems; she was already proud of standing up for her friends in some situations, and felt embarrassed in others when she was silenced. However, the school system and her teacher did not recognize or acknowledge that desire, and she was angry that they, who were supposedly in a position to help her achieve her goals, weren't actually helping at all. She reported standing up to the teacher several times at the beginning of the class, telling the teacher what she needed, but when the teacher apparently shut her down, Rosa 
grew angry and refused to speak with the teacher any more. She attempted to jump through the hoops to complete her Disability Services forms, but when she was unable to complete all of the required steps and nobody from Disability Services stepped in to assist her, she grew angry and abandoned the attempt to get accommodations. Her experiences outside of the classroom, with the judge, with the ICE officer, had empowered her to speak, and had given her the desire to continue learning English in order to learn to speak more. The discouragement from within the school sphere-the very place that was supposed to be providing help-caused Rosa to withdraw from class participation and eventually drop out. I also contend that Rosa's lack of educational background was the largest contributor to her inability to fully take advantage of the opportunities offered at Stumptown School. As Rosa claimed in excerpt (4.c) above: "Y digo yo... pero si no... ya no me quieren a ir, voy a buscar otro lado. No me voy a dejar. [laughs] / And I say...but if they don't...if they don't want me to come any more, I'm going to look for another place. I'm not going to let them do that to me [laughs]." 


\section{Chapter 5: Conclusion}

This thesis has presented a case study of one adult English language learner who has pushed back against a system that has continuously attempted to erode her agency and has ignored her total investment in learning English. For many, she is a person that could be perceived as a long list of disadvantageous characteristics: she is a woman of color, she is a Mexican living in the US, she is a single mother, she is a working grandmother, she is vision-impaired; she is not as able-bodied as her surroundings are built for; she is an English language learner (seen as a deficit by many in the US), she is a LESLLA learner (which negatively impacts her ability to work in the places she would choose), and she is a non-successful participant in an English language learning program (looking at the short-term reality of her dropping out of her class). This description could be of a totally unsuccessful learner facing insurmountable obstacles, but this is the opposite of what these data show. If we only look at the "marginalized Rosa," we ignore the Rosa who has layerd new pieces into her identity: she stands up for herself, she invests completely in learning English, and she resists the system's attempts to deny her right to make good on either investment.

Rosa's investment in learning English is an investment in a future self who could "defenderse." I have translated "defenderse" in this thesis variously as "defend" and "stand up for" herself; a popular online Spanish-English dictionary also lists "fend for oneself," "hit back," "hold on," "guard," “advocate," and "uphold" as viable translations. Klassen (1987), in his master's thesis focusing on the literacy 
practices of adult Latinos in Toronto, describes an aspiration in his participants similar to that of Rosa's desire to learn English in order to "defenderse." Klassen described "defenderse" as having two sides: a pride for fending for oneself and one's family, as well as "connotations of struggle, of staying afloat, and of fighting ot manage difficulties where defeat is a real possibility" (p. 150). Rosa, too, desired to defend herself and fend for herself, and thereby invested in her education and her imagined identity. This investment, however, was also coupled with nonparticipation in her language-learning classroom.

A classroom teacher often views "participation" as a combination of homework completion, asking questions of the teacher, completing individual, pair, and groupwork in class, and general active engagement in lessons. On most of these counts, Rosa can be considered a "non-participant" in the class that I observed her in at Stumptown. However, this lack of participation is not indicative of a lack of investment in learning English; as she stated, learning English was one of the most important parts of her life.

The system of adult education is imposing a kind of structural violence that ignores the agency and resilience of adult learners. The system at the institution where Rosa took classes exercised a form of domination that Rosa resisted. This type of resistance to institutions is described by Patricia Hill Collins:

Domination is also experienced and resisted on the third level of social institutions controlled by the dominant group: namely, schools, churches, the media, and other formal organizations. These institutions expose individuals to the specialized thought representing the dominant group's standpoint and 
interests. While such institutions offer the promise of both literacy and other skills that can be used for individual empowerment and social transformation, they simultaneously require docility and passivity." (1990, para. 24)

I conclude that her non-participation was partly her resistance to the interlocking systems of oppression (Collins, 1990) that conspire to limit her agency and partly a concession to the rigid structure of the language-learning opportunities provided that allowed her physical disabilities and time constraints no dispensation. Rosa willingly stepped into the arena of the language-learning classroom, but once inside, she did not participate in ways that the institution anticipated or desired. It is interesting to compare Rosa's non-participation in the classroom with Katarina and Felicia from Norton's seminal study on investment and nonparticipation (Norton, 2001); both Katarina and Felicia grew angry at their teachers and stopped going to their English classes. Norton has argued that the students' anger at the teachers stemmed from the teachers' denying or ignoring integral parts of the students' identities:

In sum, for both Felicia and for Katarina, their extreme acts of nonparticipation were acts of alignment on their part to preserve the integrity of their imagined communities [professionals for Katarina, Peruvians for Felicia]. Non-participation was not an opportunity for learning from a position of peripherality, but an act of resistance from a position of marginality. (2001, p. 165)

Rosa reported that when she tried to ask her teacher questions, the teacher 
grew angry, so Rosa quit voluntarily talking to the teacher altogether (see line 49 in excerpt 4.d above: "ya casi mejor no hablo / perhaps now I almost don't speak"). While she still attended the Intermediate-Low class, her active participation in the class was markedly low. Rosa's continued participation in the class can be attributed to her great regard for her classmates, her belief that the best way for her to learn was by being in a formal educational setting with a teacher, and her tenacity and perseverance to leave the narratives of domestic life that had been forced on her for most of her life.

Rosa's "right to speak" English (Norton, 2000) is limited in her home life, her work life, and her school life. Rosa, however, is actively resisting this marginalization and continued to seek areas to further her English and digital literacy learning (she bought a computer to practice on at home; she was looking for a new job in a restaurant where she could speak to customers; she spoke to her tablemate in class, if not to the teacher).

Rosa is a person of exceptional wisdom and resilience, and her experience is by no means unique. The Hispanic women interviewed in Rockhill's (1987) study of gender and literacy in Los Angeles made eerily similar answers to those Rosa gave in my interviews with her. The emergent readers in Klassen's (1987) study in Canada expressed aspirations and barriers almost identical to Rosa's. The LESLLA learners expressing a simultaneous hunger to learn and frustration in not knowing how to learn in Whiteside's (2007) study in the Bay Area could have each been Rosa. Each of the participants in Rockhill's, Klassen's, and Whiteside's studies were people who were learning to become literate while learning English with important stories 
for applied linguists and ESL educators to learn from, and Rosa's story, too, is powerful enough to illuminate a system at work.

I have documented throughout this thesis that Rosa's ESL class (and the institution hosting the class) provided a form of structure that engaged in practices that did not attend sufficiently to who the learners are. Other researchers in the field have documented other forms of domination and oppression by educational systems (Canagarajah, 1993; Tollefson, 1989) and while Stumptown could be characterized as a benevolently neglectful school instead of an overtly violent one, I have documented the program's attempts at the removal of agency from a learner who cares. I have documented the resiliency and determination of that learner to seek a good return on her investment.

\section{Implications}

A number of theoretical, programmatic, and pedagogical implications can be drawn from the conclusions of this study.

Theoretical implications. Unlike previous research on non-participation (Norton, 2001; Skilton-Sylvester, 2002), this study showed non-participation emerging as a distinct construct from non-investment (Rosa did not fully participate in the classroom, although she remained true to her investment in learning English). This study also concurs with the findings of previous research that investment in language learning goes beyond the boundaries of particular language-learning environments (Reder, 2013), and it is therefore paramount to continue studying learners' investment in learning English with reference to their investments in other areas of their lives. 
Through its discursive power in shaping how we understand the world around us, research privileges certain groups' knowledge and certain people's spaces of knowing. This research has purposefuly privilged Rosa's voice, and in doing so, there is a power that should not be underestimated. Including learner voices in research gives a depth of understanding of the complex factors underlying investment. However, it should be made very clear that in this thesis, I have not "given" Rosa a voice, and nor would I like to claim that merely hearing her voice is enough. As Ramanathan, Pennycook and Norton (2010) state in their introduction to Hernández-Zamora's book on Decolonizing Literacy, claiming that merely "opening a space for the voices of the disenfranchised can bring about change...fail[s] to show how this romanticized vision of voice brings about change" (pp. xi-xii), and that instead, we need to listen to people's voices and learn from them:

...what it is in the lives of marginalized, alienated, unschooled, and colonized subjects that has enabled them to move from silence to a capacity to articulate their worlds. Once we understand the deeply political nature of literacy, of poverty, and of voice, we can start to think in terms of a literacy education that may enable multiple and diverse futures. (p. xii)

Programmatic/Systemic implications. The strongest statement that I can make is that LESLLA learners need far more programmatic and in-class support than they are currently provided, and this situation must change if we hope to provide equal human rights for all learners. Rosa is "hungry" to learn English, but the system is not hungry to provide her with adequate learning resources. The 
adult education system should be desperate to help every student that passes through its front doors.

The Longitudinal Study of Adult Learning (LSAL) has shown that educational programs in the lives of adult learners can change those adults' economic futures. Reder (2014a) has shown through three different statistical models that adults who participate in educational programs for at least 100 hours have significantly higher incomes after they complete the program than when they started (for LSAL participants, learners' post-program incomes rose by about $\$ 10,000$ per year in 2013 dollars, p. 4). When such significant gains can be made by people who successfully participate in programs, programs should not be so eager to kick students out if they aren't making learning benchmarks quickly enough. About 26\% of LSAL participants had literacy proficiency scores of "Basic" or "Below Basic" (on standard reporting levels for National Assessment of Adult Literacy; see Reder, 2010), and analyses demonstrated that adults with low literacy skills ("Basic" and "Below Basic") compared to higher literacy skills earned several thousand dollars less per year. Furthermore, those adults whose literacy proficiency increased over the course of the study earned significantly higher wages than those whose literacy proficiency did not change or decreased, especially during years of economic recession (Reder, 2010). Therefore, it is absolutely necessary for adult education programs to provide sustained literacy training and support for all learners and especially those with low literacy skills. Sustained training and support cannot be withdrawn after three or four terms; to do so is unconscionable.

Beyond the realm of economics, sustained literacy support is necessary for 
assisting learners in resisting the forms of domination exercised upon them precisely because they are not literate. As "writing is validated as a method of knowing" (Richardson, 2000, p. 929, as cited by Kouritzin, 2002, p. 127), the knowledge of people with low literacy skills is often de-valued by mainstream US society (Clair \& Sandlin, 2004), and the informal methods of learning of those who lack formal education are especially ignored in formal educational settings (Ramírez-Esparza et al., 2012, p. 544). Regarding her informal learning, Rosa first learned English informally ("nomás así en la calle / just in the streets like that," Interview \#1), and by the time I knew her, she also had some degree of Spanish literacy, which certainly wasn't learned in a formal situation. She also learned many other work skills informally: as she reported telling her classmate, she learned to be a welder even though she didn't study to be one (lines 41-42 in excerpt 4.a). However, these skills in being able to learn informally did not fully translate in the formal classroom environment: formal activities like dictation and homework assignments where she had to write many examples of a grammar form to show mastery were extremely difficult for her. Therefore, ESL programs that desire to help create a more just future should recognize that they will have LESLLA learners in their classrooms and should both champion learners' literacy learning as well as uphold learners' informal methods of learning.

Programs also need to recognize learners' investment. Pittaway argues that investment

...has the power to transform students to claim the right to speak and defend against obstacles they may encounter outside the classroom and even within 
themselves. Engaging investment is a process of leveraging learners' identities to help them achieve their goals and realize their potential for personal and/or professional growth. This process has the power to orient classroom practice in a way that truly acknowledges students for the complexity underlying their motivations, desires, and hopes for the future. (p. 216) Many researchers have shown that investment and agency are building blocks in learning: Pittaway summarizes research on investment, stating, “[e]ngaging investment is a necessary condition for second language acquisition (SLA) because investment embodies the affective factors (e.g., anxiety, motivation, and self-confidence) that many scholars assume play a fundamental role in SLA (Lightbown \& Spada, 1999; Spolsky, 1989)" (p. 204). Moreover, understanding agency is necessary in understanding learner success (Miller, 2010; Pavlenko \& Lantolf, 2000). Individuals' agency can be recognized and celebrated in many ways: encouraging and allowing "creative discursive agency" (Flowerdew \& Miller, 2008) in how learners express themselves within the classroom is the easiest method (from a programmatic perspective) to ensuring that all learners' investments are recognized as being equally important; a more challenging, but perhaps more ultimately fruitful approach would be to reform educational programs to revolve entirely around the learner in the form of personal learning plans instead of hoping to force the learner to conform to the program's expectations. Reder (2014b) uses the metaphor of the "parking lot" to describe how programs want the seats in the classrooms full for the longest amount of time possible, but a "busy intersection" 
model would allow learners to pass in and out of programs as becomes necessary in their lives and gain what they need while in the program before leaving again. No matter how it is accomplished, programs and teachers who desire the success of their learners need to foster learner agency and recognize learners' investments in language learning and in other parts of their lives.

It is particularly troubling that, in mainstream US culture, "illiteracy" is equated with "immorality" (Rockhill, 1987), and yet the very institutions that purport to support emergent readers (and thereby "uplift" them) often fall back into moralizing and infantilizing discourses surrounding the learners they serve. In a casual conversation (outside the purview of this research) with an administrator of Stumptown, I brought up Stumptown's practice of removing students from the program if they could not satisfactorily pass a class after three attempts, and the administrator replied that Stumptown doesn't provide "adult day care." This comment is by no means a full representation of Stumptown's policy, nor is it likely representative of the administrator's complete approach towards ESL, but as a oneoff remark, it is very troubling.

Neoliberal narratives of individual success have infiltrated educational systems (Kramsch, 2014) and the consequences are that programs and classrooms are designed to ensure that learners exhibit consistent behaviors and that society maintains order. Every time an individual does not follow expectations, the system reacts negatively to the individual, which ignores the power of human potential. Rosa frequently failed the examinations given to her in which she was supposed to show progress, so she was on the verge of being kicked out of the program, without 
the program's focusing at all on Rosa's investment in learning.

Furthermore, teachers who choose to try to foster learner agency by providing more freedom and opportunity in the classroom often end up in a program's crosshairs for not conforming to set standards (Auerbach, 1986). We educators cannot continue designing programs that do not maintain the joy and freedom of learners.

Pedagogical implications. This study led me to reflect on many aspects of my own teaching. After I considered excerpts (4.c) and (4.d), a salient finding for me, as a teacher, was that Rosa's view of her teachers' agency is markedly different from what I view to be within the realm of possibility of a teacher's choices. For example, in excerpt (4.c), Rosa describes how upset she was when her current teacher asked her to take her doctor's letter to Stumptown's disability services office; in excerpt (4.d), Rosa describes her frustration that the teacher has a pre-set stack of papers to go through, and her confusion over why she had to change seating partners in every class. As a teacher, I see the value of not giving special accommodations to students without the specific approval of a disability services office, and I can certainly see the value in having a curriculum and in having class routines such as asking students to sit next to new people every day. However, it is now equally clear to me that if I am to succeed in my wish to empower students and give them the tools to find their voices in English, I need to be very careful to help students understand the intended purposes behind systems such as the disability services office, or the rationales behind having a curriculum for a class, or the motivations behind asking students to sit next to new classmates each day. In 
addition, it is absolutely necessary to negotiate various aspects of a planned class whenever possible, such as supplementing a planned curriculum with materials the students express a need for, or consulting the students on their preferred seating arrangement and coming to a compromise that will satisfy the students and retain pedagogical value.

We as educators need to learn how to really listen to our students and learn from them just as much they might learn from us (Freire, 1970; Ullman, 2010). Classrooms are contact zones (Pratt, 1991); we as teachers need intercultural competence, a key feature of which is perceptual acuity. In many contexts, learners' lives can be a central part of the classroom and perhaps the curriculum (Auerbach, 1992; Weinstein, 1999). However, it is also important to respect learners' privacy and to develop skills of asking students in a meaningful and nonessentializing way about their lives (Kubota, 2001). An example: during one of the classes that I observed as a part of this study, the teacher asked students to line up by how long they'd been in the US for. Rosa was near the end of the line of students who had been here the longest, stating she had about 16 years of living in the US. A few days later, during our third interview, Rosa was describing her arrival in the US and told me she had been here almost 30 years:

(5.a) Excerpt from Interview \#3:

1 R- Ya casi, casi voy a completar, sin mentirte, casi treinta años en Estados 2 Unidos.

3 J-Wow

4 R- Yo me venía bien joven.

5 J-Wow

6 R- ¡Y no se ni hablar inglés, pero allí voy! [laughs]

7 J- Treinta años en Estados Unidos. Un día en la clase, yo estaba en la clase- 
8 R- ¡Yo les miento a los de la clase! [laughs]

9 J- ¡Sí!

10 R- ¡Porque no quiero, no quiero que sepa la verdad! Porque, yo siempre digo, "Oh, tengo once años.” “Oh, tengo-” pero pongo más de diez años

J- Creo que dijo

R- Nunca pongo

J- dieciséis ese día en la clase

R- Sí, no, no pongo todo el tiempo. El tiempo que he estado acá no lo pongo. Nomás pongo cierto tiempo, que dicen, “¡Ao, tantos años y no sabes inglés!” Así lo van a dec- ¡Y lo dicen! Mucha gente así lo dice. Pero hay [...] mejores personas que yo. Hay algunas personas que toda su vida ha sido aquí, y no saben nada. Nada nada. Pero yo entiendo porque nos dedicamos mucho al trabajo. Cuando dedicamos mucho al trabajo, no tenemos tiempo ni siquiera de [...] por eso. Pero sí, yo en la escuela, nunca pongo exactamente de qué año, que año vine. [...] "Ooh, tanto tanto; ooh, tiene tanto ésta." [laughs] J- Bueno, tiene razón...

24 R- Sí, porque hay una señora que a veces dice, “¡Ay!” Porque los demás compañeros sometimes dicen, “¡Tanto y no sabes nada!” [laughs] Y que hay personas que tienen, qué, como tres, cuatro meses, el primer trimestre que entran y ya saben bastante inglés. Pero vienen estudiados de su país. Yo no.

\section{(5.a) GLOSSED Excerpt from Interview \#3:}

1 R- Now I'm almost, almost, going to have spent, without lying to you, almost

230 years in the United States.

3 J- Wow

4 R- I came here very young.

5 J-Wow

6 R- And I don't know how to speak English, but there I go! [laughs]

7 J- Thirty years in the United States. One day in class, I was your class-

8 R-I lie to the people in class! [laughs]

9 J- Yes!

10 R- Because I don't want, I don't want them to know the truth! Because, I always say, "Oh, I've been here 11 years." "Oh, I've-", but I always say more than 10 years.

13 J- I think you said

14 R- I never say

15 J- 16 that day in class

R- Yes, I don't, I don't say the whole time. The amount of time that I've been here I don't say. I only say a certain amount of time, because they say, "Ao, so many years and you don't know English!” They're going to say it like thatAnd they do say it! Many people say it like that. But there are [...] people better than me. There are some people who have been here their whole lives, and they don't know anything. Nothing, nothing. But I understand

22 because we dedicate ourselves a lot to working. When we dedicate ourselves 
23 to work, we don't have time not even to [...] for that reason. But yes, in

24 school, I never say exactly what year, what year I came. [...] "Ooh, so long, so

25 long; ooh, this woman's been here for so long." [laughs]

26 J- Well, you're right...

27 R- Yes, because there's a woman who sometimes says, "Ay!" Because the rest

28 of my classmates sometimes say, "So long and you don't know anything!"

29 [laughs] And there are people who've been here, what, like three, four

30 months, the first quarter that they come in they already know a good amount

31 of English. But they come educated from their country. I didn't.

Therefore, teachers need to strike a balance between respecting students'

privacy and providing students space with which to bring their outside experiences

into the classroom when they desire. In addition, this excerpt shows Rosa's ability

to navigate the continuum of academic genres - there is a purpose for saying a

number that is not the truth-and if teachers can recognize when students are using

such strategies to succeed, teachers need to respect and honor these strategic

linguistic choices.

Another element of helping students bring their outside experiences into the classroom, or helping students learn English in the classroom that will help them better cope in outside experiences, is to teach English that will help learners stand up for themselves. Often ESOL classes will present an "idealised world where noone is ever unhappy, sick or poor" (Wallace, 2006, p. 79). Rosa argued that she needed to be able to discuss "delicate things" and "horrible things" in her everyday life:

\section{(4.e) Excerpt from Interview \#4:}

1 R- Y, para el paso del inglés que, que yo he tomado, pues sí nos han dado un

2 poquito de una cosa, un poquito de otra, pero sin embargo, ¡mucho más

3 todavía! [...] necesita. Y para eso, pienso que es muy difícil. Es muy difícil,

4 como, tomar las clases para la profesora y para el estudiante, porque, es

5 bastantes cosas. Imagínate que como, de repente, hay que decir, "piedra," o 
6 de repente hay que decir, "una bala," o de repente hay que decir que, "Fulano

7 mató a fulano," Esas son cosas muy delicadas. O que de repente hay que

8 decir que encuentres un muerto allá, y esas son cosas que son espantosas.

9 Entonces, ¿cómo puedes defenderte tú, ya por la ley, si llegas ver un caso de

10 criminales? Allí son cosas muy delicadas, que dices, wow, mejor muchos de

11 nosotros latinos, mejor no abrimos la boca, porque tenemos miedo que ese

12 caso, que en vez de que, que uno... ayuda a la persona, al contrario a nosotros

13 nos meten a la cárcel. Entonces, si ves algo, mejor no digas nada.

\section{(4.e) GLOSSED Excerpt from Interview \#4:}

1 R- And, for the path of English that, that I've taken, well they have given us a 2 little bit of one thing, a little bit of another, however, [there is] still so much 3 more! [...] need. And for that, I think it's really difficult. It's difficult, like, to 4 take the classes for the teacher and for the student, because, it's a lot of 5 things. Imagine that like, all of a sudden, you have to say "rock," or suddenly 6 you have to say, "a bullet," or suddenly you have to say, "So-and-so killed so7 and-so," These are really delicate things. Or suddenly you have to say that 8 you've found a dead person there, and these are horrible things. So, how are 9 you going to stand up for yourself in front of the law, if you end up seeing a 10 criminal case? These are really delicate things, that you say, wow, a lot of us 11 Latinos had better not open our mouths, because we're afraid that in that 12 case, that instead of, of you... helping the person, on the contrary they put us 13 in jail. So, if you see anything, you'd better not say anything.

Putting each of these recommendations into place in the day-to-day of teaching is a challenge, but there are certainly successful ways of implementing them. Ullman (2010) describes setting up role plays between students who act as ICE officers and people caught in raids; Morgan (1997) shows how teachers can simultaneously give instruction on modal verbs and help students come up with real solutions to real problems they have in their lives.

As a novice teacher currently teaching in an intensive English language program, I am constantly struggling to affirm learners' voices and stay true to my own teaching philosophy, but I hope to continue improving as I gain experience and as I learn from my students. The task of trying to understand how each individual 
student's identity, social context of their life, and the classroom space affect his or her investment into the practices of my classroom, when I have up to 90 students in classes every month with a new rotation of 90 students during the next month and 90 the month after that, ad infinitum, seems impossible. However, I am learning small strategies that have helped me. I take notes on each student as the month progresses and keep a personal record what I've learned about students. In fact, I do see some students again after the first month of learning: sometimes they appear again in a later class in a different level. In such cases, I add to my notes and can get to know the student on a deeper level. In addition, during many classes I have students do projects on a topic of significance to them in an attempt to learn what is important to my students. I bring up tough issues or let students bring up issues that affect their lives, and we discuss solutions to those problems. However, it will be a lifelong journey for me to continue learning how to learn from my students, and learn how to be a better teacher. 
References

Ahearn, L. (2010). Agency and language. In J. Jaspers, J.-O. Östman \& J. Verschueren (Eds.), Society and language use: Handbook of Pragmatics Highlights (Vol. 7, pp. 28-48). Philadelphia: John Benjamins Publishing Co.

Allen, R. L. (1999). The socio-spatial making and marking of 'us': Toward a critical postmodern spatial theory of difference and community. Social Identities, 5(3), 249-277.

Anderson, B. R. O'G. (2006). Imagined communities: Reflections on the origin and spread of nationalism (revised edn.). New York: Verso. Retrieved from http://hdl.handle.net/2027/heb.01609.0001.001

Atay, D. \& Ece, A. (2009). Multiple identities as reflected in English-language education: The Turkish perspective. Journal of Language, Identity, and Education, 8, 21-34.

Auerbach, E. (1986). Competency-based ESL: One step forward or two steps back? TESOL Quarterly, 20, 411-429.

Auerbach, E. (1992). Making meaning making change: participatory curriculum development for adult ESOL literacy. McHenry, IL: Centre for Applied Linguistics and Delta Systems.

Baker, W. (2009). The cultures of English as a lingua franca. TESOL Quarterly, 43, $567-592$.

Barker, V. \& Giles, H. (2002). Who supports the English-Only movement?: Evidence for misconceptions about Latino group vitality, Journal of Multilingual and 
Multicultural Development, 23(5), 353-370.

Baynham, M. \& Simpson, J. (2010). Onwards and upwards: Space, placement, and liminality in adult ESOL classes. TESOL Quarterly, 44, 420-440.

Bigelow, M. Delmas, R., Hansen, K., \& Tarone, E. (2006). Literacy and the processing of oral recasts in SLA, TESOL Quarterly, 40, 665-689.

Bonilla-Silva, E. (2003). Racism without racists: Color-blind racism and the persistance of racial inequality in the United States. Lanham, MD: Rowman and Littlefield Publishers.

Bourdieu, P. (1991). Language and symbolic power. (G. Raymond \& M. Adamson, Trans.) Cambridge, MA: Harvard University Press.

Bronfenbrenner, U. (2005). Making human beings human: Bioecological perspectives on human development. Thousand Oaks, CA: Sage.

Brooks, C. (2004). Race, politics, and denial: Why Oregon forgot to ratify the Fourteenth Amendment, Oregon Law Review, 83, 731-762.

Burghart, D. (2014). Dissecting the nativist victory in Oregon, Institute for research and education on human rights. Retrieved from http://www.irehr.org/issueareas/nation-state-and-citizenship/614-dissecting-the-nativist-victory-inoregon

Canagarajah, S. (1993). Critical ethnography of a Sri Lankan classroom: Ambiguities in student opposition to reproduction through ESOL. TESOL Quarterly, 27, pp. 601-626.

Carroll, S., Motha, S., and Price, J. N. (2008). Accessing imagined communities and reinscribing regimes of truth. Critical Inquiry in Language Studies, 5(3), 165- 
191.

Carter, B. \& Sealey, A. (2000). Language, structure, and agency: What can realist social theory offer to sociolinguistics? Journal of Sociolinguistics, 4(1), 3-20.

Cervatiuc, A. (2009). Identity, good language learning, and adult immigrants in Canada. Journal of Language, Identity, and Education, 8, 254-271.

Charmaz, K. (2006). Constructing grounded theory: A practical guide through qualitative analysis. Los Angeles: Sage.

Clair, R., and Sandlin, J.A. (2004). Incompetence and intrusion: On the methaphorical use of illiteracy in U.S. Political discourse. Adult Basic Education, 14(1), 45-59. Collins, P. (1990). Black feminist thought: Knowledge, consciousness, and the politics of empowerment. Boston: Unwin Hyman. Retrieved from http://www.hartford-hwp.com/archives/45a/252.html

Condelli, L. Wrigley, H. \& Yoon, K. (2008). “What works” for adult literacy students of English as a second language. In S. Reder \& J. Bynner (Eds.), Tracking Adult Literacy and Numeracy Skills: Findings from Longitudinal Research (pp. 132159). New York: Routledge.

Cooke, M. (2006). "When I wake up I dream of electricity": The lives, aspirations and 'needs' of Adult ESOL learners. Linguistics and Education, 17, 56-73.

Cowie, N. (2009). Observation. In J. Heigham \& A. Croker (Eds.), Qualitative research in applied linguistics: A practical introduction (pp. 165-181). New York: Palgrave Macmillan.

DeCapua, A. and Marshall, H. (2010). Students with limited or interrupted formal education in US classrooms, Urban Review, 42, 159-173. 
Dörnyei, Z. (2009). The L2 motivational self system. In Z. Dörnyei \& E. Ushioda (Eds.), Motivation, language identity, and the L2 self (pp. 9-42). Bristol, UK: Multilingual Matters.

Earl-Castillo, L. (1990). The effects of education in L1 and other factors on the development of oral proficiency in L2 among adults. New York: ERIC.

Firth, A. \& Wagner, J. (1997). On discourse, communication, and (some) fundamental concepts in SLA Research. The Modern Language Journal, 81(3), 285-300.

Flowerdew, J. \& Miller, L. (2008). Social structure and individual agency in second langage learning: Evidence from three life histories. Critical Inquiry in Language Studies, 5(4), 201-224.

Freire, P. (1970). Pedagogy of the oppressed. New York, NY: Continuum Press.

Gibson, K. (2007). Bleeding Albina: A history of community disinvestment, 19402000. Transforming Anthropology, 15(1), 3-25.

Gordon, D. (2004). "I'm tired. You clean and cook.": Shifting gender identities and second language socialization. TESOL Quarterly, 38, 437-457.

Haneda, M. (2005). Investing in foreign-language writing: A study of two multicultural learners. Journal of Language, Identity, and Education, (4)4, 269-290.

Hartman. A. (2003). Language as oppression: The English-only movement in the United States. Socialism and Democracy, 17(1), 187-208.

Holland, D., Lachicotte Jr., W., Skinner, D., Cain, C. (1998). Identity and agency in cultural worlds. Cambridge, MA: Harvard University Press. 
HoSang, D. (2010). Racial propositions: Ballot initiatives and the making of postwar California. Berkeley: University of California Press.

House, J. (2003). English as a lingua franca: A threat to multilingualism? Journal of Sociolinguistics, 7, 556-578.

Ibrahim, A. E. (1999). Becoming Black: Rap and hip-hop, race, gender, identity, and the politics of ESL learning. TESOL Quarterly, 33, 349-369.

Imarisha, W. (2013). A hidden history. Oregon Humanities Magazine, Summer 2013. Retrieved from http://walidah.com/files/hidden $\% 20$ history $\% 20$ section $\% 20$ skin $\% 200 R \% 2$ 0humanities\%20magazine 0.pdf

Kanno, Y. \& Norton, B. (2003). Imagined communities and educational possibilities. Journal of Language, Identity, and Education, 2, 241-249.

King, B. W. (2008). "Being gay guy, that is the advantage”: Queer Korean language learning and identity construction. Journal of Language, Identity and Education, 7, 230-252.

Kinginger, C. (2004). Alice doesn't live here anymore: Foreign language learning and identity construction. In A. Pavlenko \& A. Blackledge (Eds.), Negotiation of identities in multilingual contexts, pp. 219-242.

Klassen, C. (1987). Language and literacy learning: The adult immigrant's account. Unpublished masters thesis, Ontario Institute for Studies in Education/University of Toronto, Canada.

Kouritzin, S. (2002). The "Half-Baked" concept of "raw" data in ethnographic observation. Canadian Journal of Education, 27(1), 119-138. 
Kramsch, C. (2014, March). Neoliberalism and its impact on language, research, and learning. Discussion presented at the American Association for Applied Linguistics 2014 Conference, Portland, OR.

Kubota, R. (2001). Discursive construction of the images of U.S. classrooms. TESOL Quarterly, 35, 9-38.

Kubota, R. (2002). The author responds: (Un)raveling racism in a nice field like TESOL. TESOL Quarterly, 36, 84-92.

Kumaravadivelu, B. (2008). Cutlural globalization and language education. New Haven, CT: Yale University Press.

Langer, E. (2004). A hundred little Hitlers. New York: Picador.

Lantolf, J.P. \& Pavlenko, A. (2001). (S)econd (L)anguage (A)ctivity theory: Understanding second language learners as people. In M.P. Breen (Ed.), Learner contributions to language learning (pp. 141-158). Harlow, England: Longman.

LaRossa, R. (2005). Grounded theory methods and qualitative family research. Journal of Marriage and Family, 67, 837-857.

Lee, E. (2008). The "other(ing)" costs of ESL: A Canadian case study. Journal of Asian Pacific Communication, 18, 91-108.

Lincoln, Y. S., \& Guba, E. (1985) Naturalistic inquiry. Beverly Hills, CA: Sage.

Lyons, Z. (2009). Imagined identity in the L2 self in French. In Z. Dörnyei \& E. Ushioda (Eds.), Motivation, identity, and the L2 self (pp. 229-247). Bristol, UK: Multilingual Matters.

Marshall, S. (2010). Re-becoming ESL: multilingual university students and a deficit 
identity. Language and Education, 24(1), 41-56.

Mathews-Aydinli, J. (2008). Overlooked and understudied? A survey of current trends in research on adult English language learners. Adult Education Quarterly, 58(3), 198-213.

McKay, S. \& Wong, S. C. (1996). Multiple discourses, multiple identities: Investment and agency in second language learning among Chinese adolescent immigrant students. Harvard Educational Review, 66(3), 577-608.

McParland, D. (2014). Is self-sufficiency really sufficient? A critical analysis of federal refugee resettlement policy and local attendant English language training in Portland, Oregon (Unpublished Master's thesis). Portland State University, Portland, OR.

Menard-Warwick, J. (2004). "I always had the desire to progress a little": Gendered narratives of immigrant language learners. Journal of Language, Identity, and Education, 3, 295-311.

Menard-Warwick, J. (2014). English language teachers on the discursive faultlines: Identities, ideologies, and pedagogies. Bristol, UK: Multilingual Matters.

Mercer, S. (2011). Understanding learner agency as a complex dynamic system. System, 39, 427-436.

Miller, E. R. (2009). Orienting to "being ordinary": The (re)construction of hegemonic ideologies in interactions among adult immigrant learners of English. Critical Inquiry in Language Studies, 6(4). 315-344.

Miller, E. R. (2012). Agency, language learning, and multilingual spaces. Multilingua, $31,441-468$ 
Morgan, B. (1997). Identity and intonation: Linking dynamic processes in an ESL classroom. TESOL Quarterly, 31, 431-450.

Morgan, B. (2004). Modals and memories: A grammar lesson on the Quebec referendum on sovereignty. In B. Norton \& K. Toohey (Eds.), Critical pedagogies and language learning (pp. 158-175). Cambridge, UK: Cambridge University Press.

Motha, S. (2006). Racializing ESOL teacher identities in U.S. K-12 public schools. TESOL Quarterly, 40, 495-518.

Murray, G. (2009). Narrative inquiry. In J. Heigham \& A. Croker (Eds.), Qualitative research in applied linguistics: A practical introduction (pp. 45-65). New York: Palgrave Macmillan.

Murphey, T., Jin, C., \& Li-Chi, C. (2005). Learners' constructions of identities and imagined communities. In P. Benson \& D. Nunan (Eds.), Learners'stories: Difference and diversity in language learning (pp. 83-100). Cambridge, UK: Cambridge University Press.

Nokes, G. (2009). Massacred for gold. Corvallis, OR: Oregon State University Press. Norton, B. (2000). Identity and language learning: Gender, ethnicity and educational change. Harlow, UK: Pearson Education/Longman.

Norton, B. (2001). Non-participation, imagined communities and the language classroom. In M. Breen (Ed.), Learner contributions to language learning: New directions in research (pp. 159-171). Essex, UK: Pearson Education Limited.

Norton, B. (2013). Identity and language learning: Extending the conversation. Bristol, UK: Multilingual Matters. 
Norton Peirce, B. (1995). Social identity, investment, and language learning. TESOL Quarterly 29, 9-31.

Norton, B., \& Toohey, K. (2011). Identity, language learning, and social change. Language Teaching, 44(4), 412-446.

Office of Career, Technical, and Adult Education. (2014). National Reporting System, Oregon, Program Year 2013. Retrieved from https://wdcrobcolp01.ed.gov/CFAPPS/OVAE/NRS/tables/index.cfm

Pac, T. (2012). The English-Only movement in the US and the world in the twentyfirst century. Perspectives on Global Development and Technology, 11, 192210.

Padín, J.A. (2005). The normative mulattoes: The press, Latinos, and the racial climate on the moving immigration frontier. Sociological Perspectives, 48(1), 49-75.

Pavlenko, A. \& Blackledge, A. (2004). Negotiation of identities in multilingual contexts. Clevedon, UK: Multilingual Matters.

Pavlenko, A. \& Norton, B. (2007). Imagined communities, identity, and English language teaching. In J. Cummins \& C. Davison (Eds.), International handbook of English language teaching (pp. 669-680). New York: Springer.

Pavlenko, A. \& Lantolf, J. (2000). Second language learning as participation and the (re)construction of selves. In J. Lantolf (Ed.), Sociocultural theory and second language learning (pp. 155-178). Oxford: Oxford University Press.

Perry, F. (2011). Research in applied linguistics: Becoming a discerning consumer. Mahwah, NJ: Lawrence Erlbaum. 
Pittaway, D. (2005). Investment and second language acquisition. Critical Inquiry in Language Studies, 1(4), 203-218.

Pratt, M. (1991). Arts of the contact zone. Profession, 33-40.

Rajadurai, J. (2010a). "Malays are expected to speak Malay": Community ideologies, language use and the negotiation of identities. Journal of Language, Identity, and Education, 9, 91-106.

Rajadurai, J. (2010b). Speaking English and the Malay community: The struggle for participation and the negotiation of identities. Indonesia and the Malay World, 38(111), 289-301.

Ramanathan, V. Pennycook, A. and Norton, B. (2010). Preface. In G. HernándezZamora, Decolonizing literacy: Mexican lives in the era of global capitalism (pp. ix-xii). Bristol, UK: Multilingual Matters.

Ramírez-Esparza, N., Harris, K., Hellermann, J., Richard, C., Kuhl, P., Reder, S. (2012). Socio-Interactive practices and personality in adult learners of English with little formal education. Language Learning, 62(2), 541-570.

Read, R. (2002). The Oregonian investigates mistreatment of foreigners. Nieman Reports, Winter 2002, 27-29.

Reder, S. (2010). Adult literacy development and economic growth. Washington, DC: National Institute for Literacy.

Reder, S. (2013, August). Expanding emergent literacy practices: Busy intersections of context, practice and cognition. Plenary session at the Low Educated Second Language and Literacy Acquisition 2013 Symposium, San Francisco, CA.

Reder, S. (2014a). The impact of ABS program participation on long-term economic 
outcomes. Washington, D.C.: U.S. Department of Education, Office of Career, Technical, and Adult Education.

Reder, S. (2014b, November). Understanding the contribution of short-term adult education programs to lifelong and life-wide learning. Plenary session at the Oregon Teachers of English to Speakers of Other Languages Fall 2014 Conference, Portland, OR.

Rockhill, K. (1987). Gender, language, and the politics of literacy. British Journal of Sociology of Education, 8(2), 153-167.

Rymes, B. \& Pash, D. (2001). Questioning identity: The case of one second-language learner. Anthropology \& Education Quarterly, 32, 276-300.

Scribner, S., \& Cole, M. (1973). Cognitive consequences of formal and informal education. Science, 182, 553-559.

Serbulo, L. \& Gibson, K. (2013). Black and Blue: Police-Community Relations in Portland's Albina District, 1964-1985. Oregon Historical Quarterly, 114(1), 637.

Sharp, D., Cole, M., \& Lave, J. (1979). Education and cognitive development: The evidence from experimental research. Monographs of the Society for Research in Child Development, 44, 1-112.

Skilton-Sylvester, E. (2002). Should I stay or should I go?: Investigating Cambodian women's participation and investment in adult ESL programs. Adult Education Quarterly, 53, 9-26.

Smallbone, C. (2006). How the west was lost. History today, 56(4), 42-49.

Stephen, L. (2007). Transborder Lives: Indigenous Oaxacans in Mexico, California, and 
Oregon. Durham and London: Duke University Press.

Sullivan, D. \& Shaw, S. (2011). Retail gentrification and race: The case of Alberta Street in Portland, Oregon. Urban Affairs Review, 47(3), 413-432.

Stroud, E. (1999). Troubled waters in Ecotopia: Environmental racism in Portland, Oregon. Radical History Review, 74, 65-95.

Tollefson, J. (1989). Alien winds: The reeducation of America's Indochinese refugees. New York: Praeger.

Toohey, K. and Norton, B. (2003). Learner autonomy as agency in sociocultural settings. In D. Palfreyman \& R. Smith (Eds.), Learner autonomy across cultures (pp. 58-72). Hampshire: Palgrave Macmillan.

Ullman, C. (2010). "I Live in Tuuk-SON": Rethinking the Contexts of Language Learning Along the Mexico-U.S. Border. TESOL Journal, 1(4), 509-519.

US Department of Education, (2014). Programs: Adult education-Basic grants to states: Funding status. Retrieved from http://www2.ed.gov/programs/adultedbasic/funding.html

US Census Bureau (2012a, May 22). Census bureau releases estimates of undercount and overcount in the 2010 census. Retrieved from http://www.census.gov/newsroom/releases/archives/2010 census/cb1295.html

US Census Bureau (2013). American fact finder: Selected population profile in the United States: 2011-2013 American Community Survey 3-Year Estimates. Retrieved from http://factfinder.census.gov/faces/tableservices/jsf/pages/productview.xhtml? 
pid=ACS 13 3YR S0201\&prodType=table

US Census Bureau State \& County QuickFacts (2014, March 27). Multnomah County, Oregon. Retrieved from http://quickfacts.census.gov/qfd/states/41/41051.html

Wallace, C. (2006). The text, dead or alive: Expanding textual repertoires in the adult ESOL classroom. Linguistics and Education, 17, 74-90.

Weinstein, G. (1999). Learners' lives as curriculum: Six journeys to immigrant literacy. Delta Systems and the Center for Applied Linguistics.

Wenger, E. (1998). Communities of practice. New York: Cambridge University Press. Whiteside, A. (2007). Who is "you"?: ESL literacy, written text and troubles with deixis in imagined spaces. In M. Young-Scholten (Ed.), Low-education second language and literacy acquisition: Research, policy and practice. Proceedings of the third annual forum (pp. 99-108). Newcastle upon Tyne, UK: Newcastle University.

Willett, J. (1995). Becoming first graders in an L2: An ethnographic study of L2 socialization. TESOL Quarterly, 29, 473-503.

Wolcott, H.F. (1994). Transforming qualitative data: Description, analysis, and interpretation. Thousand Oaks, CA: Sage.

Zhang, Z. (2006). What is lived space? Ephemera, 6(2), 219-223. 
Appendix A

Initial Interview Guide for Students*

*Note that this interview guide is in English as I originally expected the interviews to be conducted in English, but as described above, I attended to Rosa's decision to switch to Spanish.

As the interviews will become very open-ended very quickly, these questions are simply guidelines that I can go back to in order to help guide the conversation if it needs guiding. These questions aren't in any particular order here.

English now:

- Do you find it easy to speak in English?

- In general, when do you feel comfortable speaking in English and when do you feel uncomfortable using English?

Communities of practice:

- Tell me about a typical Monday. Where do you go? Who do you talk with? What languages do you speak? (And where do you speak them?)

- What kinds of people do you like to spend time with?

- Who do you speak English with?

- Where would you like to be able to use English?

- Next year, who do you imagine you'll speak English to?

- What is your favorite thing to do now? Do you think that will change? Imagine you've finished the last English class. Will you be doing different things, or the same?

- Who do you talk with in class? Why do you talk with them?

Situation in the US: 
- How long have you lived in Portland?

- Who do you live with?

- How long have you been coming to Stumptown School?

- Did you go to school in your home country? If so, for how long? What's different about school here?

- What languages do you speak? Do you get the chance to speak them often here in Portland? If so, who do you speak to?

Classroom space:

- Tell me a little bit about your English classes at Stumptown School. What have they been like?

- Walk me through a typical English class. What happens first? Who sits where? Who does what? (explore examples given by the participant.) What do you do? (Use examples from my observations in class...)

- Which class did you like the best? Why?

- Which class have you worked the hardest in?

- Do you think you're different than other people in your class? Why or why not?

Agency:

- In your experience, who makes choices in your life?

- When you're in English class, do you feel like you could do anything you wanted? Do people tell you what to do in class? What kinds of people? What do they say? Can you tell people what to do? 
- Do you ever talk with administrators at Stumptown School? What do you think they think about you?

Changing identities:

- Think of what you used to do every day when you were in beginning English. Now, think of what you do every day now that you're in intermediate English. Did anything change? (Do you do different things now? Can you do different things now? Do you feel like the same person or a different person?)

- Now, imagine what life will be like once you finish advanced English. How can you imagine yourself then? What if you finish the last level? How will you be different?

- What would your dream job be? What English skills would you need to have for that job? What sorts of things would you need to read or write? Do you think your English class at Stumptown School is helping you get that dream job? Why or why not?

- What's it like when English class is finished for the day, and you go outside Stumptown School and are not in English class? Do you feel different? (Do you think being in English class and speaking in English is the same as being outside and speaking in English? Why or why not?)

- Is there any kind of person you're sure you won't be next year? (For example, I'm positive I won't be a mother next year. I'm also positive I won't be a rock star, and I know I won't be a Type A person.)

- Is there any kind of person you're scared of becoming? 
- (If participants indicate that they're somehow changing, ask for more details.) Why do you think you're changing? Can you give me an example of how you used to think, versus how you think now? 
Appendix B

Oral informed consent script for students

Be part of an important project:

\section{IDENTITY AND THE COMMUNITY ESL CLASSROOM}

I was your literacy tutor, but now I'm not going to tutor at Stumptown School for a while because I am doing a research study. I am a student at Portland State University and I am studying to be an English teacher. I think I will be a better English teacher if I learn more about who my students are and what they think about learning English at Stumptown School.

\section{What will you have to do?}

If you decide to take part in this project:

$>$ You will talk with me four or five times at a time that is good for you. We will talk every other week. This will take about one hour.

$>$ I will record our conversations with a digital audio recorder.

\section{Why have you been asked to take part in this study?}

You are in an English class at Stumptown School. You do not have to be part of this study.

\section{Are there any risks? Could anything bad happen?}

If you take part in this research:

$>$ Someone might learn your name and find out what your answers are. I will do everything I can to protect your name and identity.

$>$ You may feel uncomfortable answering some of the questions. You may skip any question you do not want to answer. Just tell me if you do not want to answer.

$>$ You may become frustrated or embarrassed when answering questions. You may stop the interview at any time.

> Your teacher at Stumptown School will know that you are a participant in this research project. I will not tell your teacher ANYTHING that you tell me. If you decide to stop being a part of this study, your teacher at Stumptown School will NOT know that you are no longer a participant. Your teacher will NOT treat you differently if you are a part of this research.

\section{What will I do to protect you?}

Your privacy is very important to me. I will do several things to protect you:

$>$ I won't tell anyone what you say in the interview.

$>$ I will not give your name to anyone. I will only share what you say in a way that no one can guess that it was you.

$>$ The audio recordings of our conversation will be kept in a locked drawer. 
Only I will listen to our conversations.

$>$ I will ask you to choose another name. I will only use that name in my research so no one will know what you said.

$>$ Your name and other personal information will be kept locked. I am the only one who will see it. I need to keep this information to know who participated.

What will you get from taking part in this research?

$>$ You may understand more about what you want to learn in English.

$>$ If you participate, you may help me learn to be a better teacher, and you will help future students.

\section{What happens if you decide not to take part in this research?}

$>$ You do not have to part in this study. Your participation is voluntary. It is your choice.

$>$ You can change your mind and stop at any time, even if you first said yes.

$>$ I will not say anything to your teacher if you say yes or no.

$>$ It will not affect any classes you are taking if you say yes or no.

$>$ It will not affect your relationship with any teachers at Stumpton School if you say yes or no.

$>$ It will not affect your relationship with me, the researcher, Jen Sacklin, if you say yes or no.

\section{Any Questions?}

If you have any questions about this study, this form or the project you can:

$>$ Talk to me when we meet.

$>$ Call me (Jen Sacklin) at (406) 223-2231

$>$ Contact Research and Strategic Partnerships, about your rights as a research participant: Market Center Building $6^{\text {th }}$ floor, Portland State University, (503) 725-4288

\section{If you say yes, what does it mean?}

This is a consent form. If you say yes, it means that:

$>$ You have listened to and understood what this form says.

$>$ You are $\mathrm{OK}$ with talking with me for this study.

$>$ You are OK with having me record you while we talk.

$>$ You know that you do not have to talk to me for this study. And even if you say yes, you can change your mind and stop at any time-it's no problem.

$>$ If you say yes to talking with me, or if you say no, your teachers will treat you the same.

$>$ You will get a copy of this form to keep for yourself. 
Appendix C

Initial email script for teacher

Dear

My name is Jen Sacklin, and I am an MA-TESOL student at PSU. For my Master's thesis, I am conducting research on students' identity and investment in learning English in a classroom. I will be conducting a series of interviews with students, but I would also like to observe the students in their ESOL classroom in order to better understand how they choose to invest in their classroom.

I would like to discuss the possibility with you of observing your ESOL

Intermediate-Mid class once a week throughout Fall of 2013. You would not be considered a participant in this study, and I would not be focusing my observations on you as a teacher. Instead, I would be focusing my observations on the students who are participating in my study. PSU's IRB has requested that it be clear to the students that I am not acting as an in-class volunteer tutor in your classroom, so my role in your classroom would be solely as an observer.

If you would be interested in allowing me to observe in your classroom in order for me to conduct research with some of your students as participants, would you be available to meet me at for a brief amount of time to discuss the study? If you have any questions, feel free to email me, call me, or ask me at our meeting.

Thank you for your time,

Jen Sacklin

(406)223-2231

jsacklin@pdx.edu 
Appendix D

\section{Initial Descriptive Codes and Emerging Categories}

\section{CHART \# 1: INITIAL DESCRIPTIVE CODES WITH ILLUSTRATIVE QUOTES}

\begin{tabular}{|l|l|}
\hline CODES & ILLUSTRATIVE QUOTES \\
\hline
\end{tabular}

Dark purple descriptive

codes are about

legal/police issues.

J- ¿De que parte en Mex, en México es usted?

R- Pues, ¿cómo te voy a decir? Sincera, sincera, sincera, de los ojos [...] [G is

shouting] no puedo mentir ni te puedo decir "o soy de aquí o soy de allá." No sé de dónde soy. Porque mi mamá no me puso, no me registró... nací en el DF, según ella, en México en el Distrito Federal. Pero, no tengo una acta para decir, "Soy... soy mexicana," "Soy oaxaqueña," "Soy veracruzana," "Soy hondureña" "Soy..." Yo no tengo acta.

Light purple descriptive

J- Usted es tan fuerte. Tan fuerte.

codes are about religion /

sobrellevar.

R- ¡Tengo que serlo! Porque, ¿cómo te diré? No tengo nadie en la, mi

alrededor, y entonces tengo que hacer como, como ese árbol más grande,

enterrado hasta abajo [laughs] para seguir, porque si no, me caigo. Sí. Y así, así está mi, así está mi situación de mi vida.

Dark orange descriptive

Tengo mis nietos. Tengo un nieto de catorc

codes are about family.

pale red descriptive codes

are about physical / health

issues.

Tengo mis nietos. Tengo un nieto de catorce años.

R. was in a bad car accident that gave her a lot of health problems.

R- Tengo muchos problemas. Del caso del accidente que tuve en el freeway llendo pa Sandy, en mi trabajo accidenté. Me volté en el freeway. Del freeway, ¿cómo decirte? de la línea primera, me adelantó el otro carro hasta el otro lado. Y la troca donde yo iba-era la troca de la compañía donde yo estaba trabajando-se quedó inservible. Y de allí me quedé ciega. Mal de la cabeza. Tengo un oyo aquí todavía hasta la fecha. Acá tengo, acá se ve. Este todo el tiempo está saliendo cosas de aquí, de mi cabeza. ¡A veces digo que eso ha de ser que el inglés también no me entra bien! Entonces, mis ojos. Mis ojos-este ojo se tapó. Yo no miraba. Yo no podía caminar. Como a los tres días de que yo tuve el accidente, yo vomitaba sangre. Hacía sangre del baño. Dije, “¡Dios mío! ¿Qué está pasando conmigo?"

bright green descriptive codes are about prior education / "personas ya preparadas" / feeling "burra"

R. did not go to school at all in Mexico and only started going to school in the US three years ago or so. Golden yellow descriptive codes are about trabajo.

bright red descriptive codes are about what I do in class / what happens in class.

R- Es que no fui a la escuela. De pequeña, nunca fui a la escuela. Todo el tiempo, mi mamá de las, como a las ¿de cinco años? ¿cuatro años? empecé a trabajar.

Light blue descriptive codes are about "what I want."

era mucho trabajo, porque yo trabajaba ya en la, en el [NAME OF BUSINESS] De limpieza yo era manager. Y yo trabajaba los siete días; diez/doce horas diarias. Era mucho trabajo aparte.

J- ¿Y cree que ha aprendido un poco más a través de esta clase?

R- ¡Oh, sí! Sí, sí se aprende, lo que pasa es que si no lo practico, lo voy a perder. J- Mm, sí. Eso sí es la verdad.

R- Sí. Sí, sí. Sí se aprende, y hay muchas cosas de, muchas palabras que yo no las sabía, muchas...como pronunciarlo, y la profesora pues lo repite varias veces para que uno más o menos se dé la idea, y sí. Después [...] muy bien, nomás que es difícil, pero hay que aprenderlas. Hay que aprender todo de las... ¿cómo se dice? Las palabras que llevan lo... la... ¿-ed?

J- Uh-huh.

R- Es un poco difícil porque, como que, el sonido está... es lo mismo pero no es lo mismo [laughs]

R- Mucha gente me dice a mí, "Yo no sé pa que vas a la escuela, si ya estás grande, ya no necesitas [...]"

"Yo voy a la escuela porque yo, yo quiero," le digo, "entender un poquito del 


\begin{tabular}{|c|c|}
\hline & $\begin{array}{l}\text { inglés, es todo. Yo quiero, no, no quiero [...], nomás poquito." Dice, "Ooh," dice, } \\
\text { "Para que aprendes inglés, vas a estar veinte años allí, nunca vas a aprender } \\
\text { bien el inglés." "¡Yo sé!" le digo "Porque yo soy mexicana, y si los, si los que } \\
\text { son nacidos acá," le digo, "le fallan, menos yo que no soy nacida aquí" [laughs] } \\
\text { le digo, "no me interesa," digo, "quiero saber un poco, es todo." }\end{array}$ \\
\hline $\begin{array}{l}\text { dark blue descriptive codes } \\
\text { are about the teacher. }\end{array}$ & $\begin{array}{l}\text { R- Sí. Creo que no le cae bien. Pero la maestra, la verdad, esa maestra ya se ha } \\
\text { portado, este año se ha port-este trimestre se portó mejor que las otras } \\
\text { veces. Como, racista, como, rara, como, creída, como, no sé. Le pregunta uno } \\
\text { una pregunta y, “Ehh!” [angry noise] salía, como... molesta. } \\
\text { J- Y ¿cuántas veces ha tomado una clase con esta profesora? } \\
\text { R- Dos veces. }\end{array}$ \\
\hline $\begin{array}{l}\text { medium blue descriptive } \\
\text { codes are about the } \\
\text { institution. }\end{array}$ & $\begin{array}{l}\text { J- Y... [NAME OF INSTITUTION] tiene una, um, tiene una regla que una persona } \\
\text { solamente puede tomar la misma clase tres veces. } \\
\text { R- Mmmhmm. } \\
\text { J- Y ¿qué opina usted de esta regla? Porque una persona puede tomar el nivel } \\
\text { uno tres veces, y si pasa, puede ir al nivel dos. Y si no pasa, no puede tomar } \\
\text { clases en [NAME OF INSTITUTION]. } \\
\text { R- Sí, es lo que nos dijeron. So, yo pienso de eso, quizás, gentes como yo que no } \\
\text { entienden, no es nomás yo, hay varias personas allí, yo pienso que lo que he de } \\
\text { ser es buscar otra maestra, es un... ¿ ¿touring? ¿cómo le llaman? ¿una persona, } \\
\text { un tutor? para que les enseñe y cobrarles más para que a ver si aprenden más. }\end{array}$ \\
\hline $\begin{array}{l}\text { Tannish/beigey brown } \\
\text { descriptive codes are about } \\
\text { "interacting with other Ss } \\
\text { in the class." }\end{array}$ & $\begin{array}{l}\text { Bueno, pero me gusta, ¿cómo te diré? relacionarme con los, con diferentes } \\
\text { personas, de los diferentes países que van a la escuela. Creo que llegan rusos, } \\
\text { llegan cambodianos, llegan japoneses, llegan, como... Guatemala, Honduras, } \\
\text { todos llegan allí, es bien, digo yo, ¡de dónde venimos de diferentes lugares y } \\
\text { [...] ganas del inglés! Unos no dicen nada, unos que ya entienden, otros que } \\
\text { escriben mucho pero no saben hablar nada [laughs]. Digo yo, ¡Wow! }\end{array}$ \\
\hline $\begin{array}{l}\text { light green descriptive } \\
\text { codes are about people on } \\
\text { the street / aquí en Estados } \\
\text { Unidos (so, a catch-all } \\
\text { category for anything not } \\
\text { related to legal issues in the } \\
\text { US). }\end{array}$ & $\begin{array}{l}\text { Tengo muchos amigos aquí. Ya tengo casi treinta años en Estados Unidos. } \\
\text { J- Wow. ¿Y todos sus años aquí en Portland? ¿O en otros...? } \\
\text { R- No, no en Washington-en California- } \\
\text { J- Oh, en Yakima, dijo- } \\
\text { R- Mmhmm, en California, pero más tiempo acá. Acá estaba más tiempo. } \\
\text { J- Aha. } \\
\text { R- Sí. En California, poco tiempo... almost [...] tres años. }\end{array}$ \\
\hline
\end{tabular}

CHART \#2: CATEGORIES EMERGING FROM THE VARIOUS CODES \& COMMENTS

\begin{tabular}{|l|l|}
\hline CATEGORIES, & Codes \\
\hline BLL & Dark purple descriptive codes are about legal/police issues. \\
\hline BARRIERS & Dark orange descriptive codes are about family. \\
\hline BARRIERS & pale red descriptive codes are about physical / health issues. \\
\hline BARRIERS & $\begin{array}{l}\text { bright green descriptive codes are about prior education / "personas ya } \\
\text { preparadas" / feeling "burra" }\end{array}$ \\
\hline BARRIERS & Golden yellow descriptive codes are about trabajo. \\
\hline BARRIERS & medium blue descriptive codes are about the institution. \\
\hline BARRIERS & dark blue descriptive codes are about the teacher. \\
\hline $\begin{array}{l}\text { RESILEINCY / SUPPORT } \\
\text { SYSTEM }\end{array}$ & Light purple descriptive codes are about religion / sobrellevar. \\
\hline PRIDE / AGENCY & Golden yellow descriptive codes are about trabajo. \\
\hline AGENCY / MOTIVATION & Light blue descriptive codes are about "what I want." \\
\hline AGENCY / MOTIVATION & Tannish/beigey brown descriptive codes are "interacting with other Ss in class." \\
\hline AGENCY (?) & $\begin{array}{l}\text { light green descriptive codes are about people on the street / aquí en Estados } \\
\text { Unidos (so, a catch-all category for anything not related to legal issues in the US). }\end{array}$ \\
\hline FATALISM & pale red descriptive codes are about physical / health issues. \\
\hline
\end{tabular}




\begin{tabular}{|l|l|}
\hline FATALISM & Light purple descriptive codes are about religion / sobrellevar. \\
\hline Category = ?? & $\begin{array}{l}\text { Tannish/beigey brown descriptive codes are about "interacting with other Ss in } \\
\text { the class." }\end{array}$ \\
\hline Category = ?? & $\begin{array}{l}\text { light green descriptive codes are about people on the street / aquí en Estados } \\
\text { Unidos (so, a catch-all category for anything not related to legal issues in the US). }\end{array}$ \\
\hline Category = ?? & bright red descriptive codes are about what I do in class / what happens in class. \\
\hline
\end{tabular}

